Athens Journal of History - Volume 6, Issue 3, July 2020 - Pages 223-286

\title{
A Satire, not a Sermon: Four Stages of Cruelty and Murder
}

\author{
By Donald C. Shelton*
}

\begin{abstract}
This paper analyses seven inter-connected William Hogarth prints in the context of medical history. Hogarth is noted for his eighteenth-century prints featuring perceptive depictions of London life. The most famous series is Four Stages of Cruelty, generally accepted as a Sermon intended to influence public opinion by drawing attention to animal cruelty. That opinion is founded on the cruel and sadistic treatment of a dog in First Stage of Cruelty; and relies on an assumption the dog is male. But, what if that dog is female? In considering that option, this paper presents evidence showing Hogarth did intend the dog as female. In so doing, the paper reaches a radically new perspective. Four Stages of Cruelty is a dark Satire, intended by Hogarth to force the cessation of murdersfor-dissection, then being undertaken by man-midwives William Smellie and William Hunter; in conducting Caesaraean experiments on pregnant women. In analysing events, the paper reveals Hogarth included within each print, recognisable likenesses of selected contemporaries, with scores of artistic puns. Realisation of the dog as female, and the series as a Satire, allows explanation of the many cryptic puns, and presents Four Stages of Cruelty as a Hogarth masterpiece.
\end{abstract}

\section{Introduction}

For 250 years the conventional view of Four Stages of Cruelty, as a William Hogarth Sermon moralising on animal cruelty, has been unchallenged. But detailed, methodical, and logical analysis shows the series as misread. Hogarth concealed, within each simple Sermon for the uneducated, a cryptic Satire for the educated; exaggerating animal cruelty in challenging cruel obstetric experiments and murders-for-dissection by man-midwives and anatomists. Overlooked by scholars has been the "front door" key placed in full view by Hogarth, a key which still works smoothly, even though unturned since 1751. That satiric key is the arrow central to The First Stage of Cruelty, incongruous when drawn to one's attention; if the prime objective was cruelty to animals, more readily available tools of torture were stick, stave, or sword. A pointing arrow and exaggerated animal cruelty were cues for Hogarth's educated peers, along with those targeted, to read Four Stages of Cruelty as a Satire. Turning the key reveals the series as alluding to events so shocking, public discussion or exposure could have risked widespread rioting, Figures 1-4.

Discussion includes Jan van Rymsdyk's anatomical drawings of 1750, as included in iconic atlases of William Smellie ${ }^{1}$ and William Hunter ${ }^{2}$. Four

*Independent Researcher, Auckland, New Zealand.

1. W. Smellie, A Sett of Anatomical Tables with Explanations (London: Freeman), 1754.

2. W. Hunter, The Anatomy of the Human Gravid Uterus (Birmingham: Baskerville), 1774. 
previously unrecorded self-portraits of Hogarth are identified, along with two portraits of the artist, Jan van Rymsdyk. Tobias Smollett's defence of murders by Hunter and Smellie enabled Smollett to be identified as author of the April 1751 satire, A Dissertation on Mr Hogarth's Six Prints. ${ }^{3}$ Classically educated, Smollett was a prolific, polemic, author, usually writing anonymously. He opposed the Caesarean experiments of Smellie and Hunter but, as a fellow Scot, defended them, whilst also attacking their actions in anonymous pamphlets. In Peregrine Pickle, Smollett parodied Hogarth as Pallet, and Fielding as Mr Spondy; the latter as part of ongoing battles with Fielding.

It has been said of investigations, "When you get closer to the truth, everything begins to fit". This occurs in reading Four Stages of Cruelty as a Satire, rather than as a Sermon. For over 250 years, and despite eighteenth-century public attendance at executions, dissections and scientific lectures, anatomy and manmidwifery have sat in a historical "no-man's land" between art, literature, law, science, and medicine. This essay criss-crosses that no-man's land to meld those disparate disciplines into a homogeneous whole. The series is shown full of irony, ridicule, humour, and cryptic puns, thereby opening new perspectives on 1745-65.

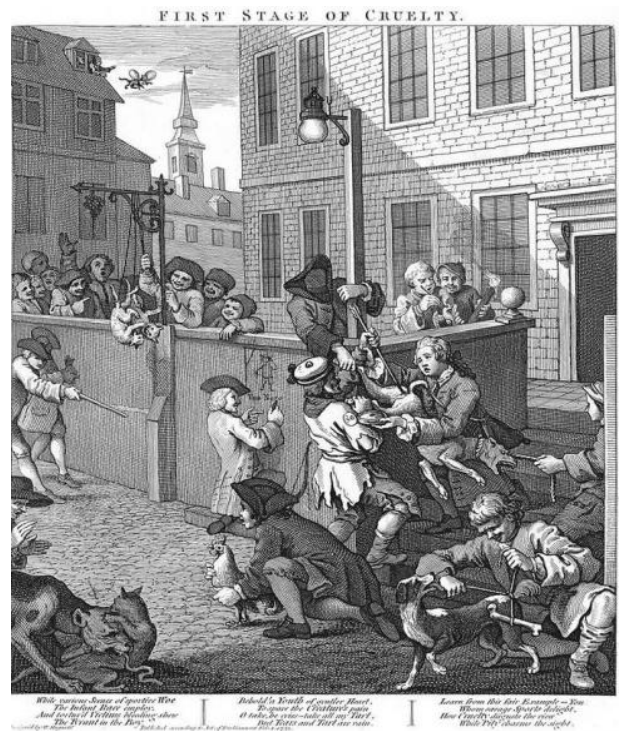

Figure 1. First Stage of Cruelty - 1751

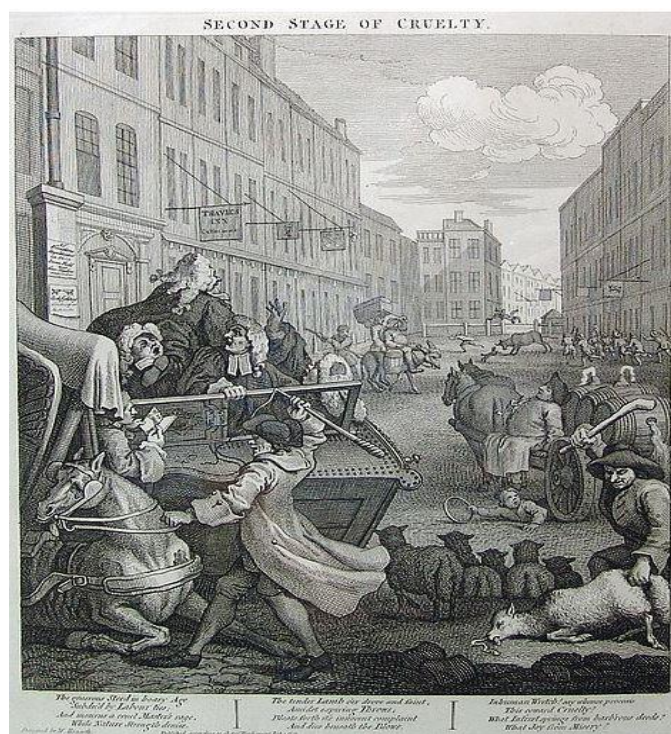

Figure 2. Second Stage of Cruelty - 1751

3. T. Smollett, A Dissertation on Mr Hogarth's Six Prints ... (London: Dickinson), 1751. 


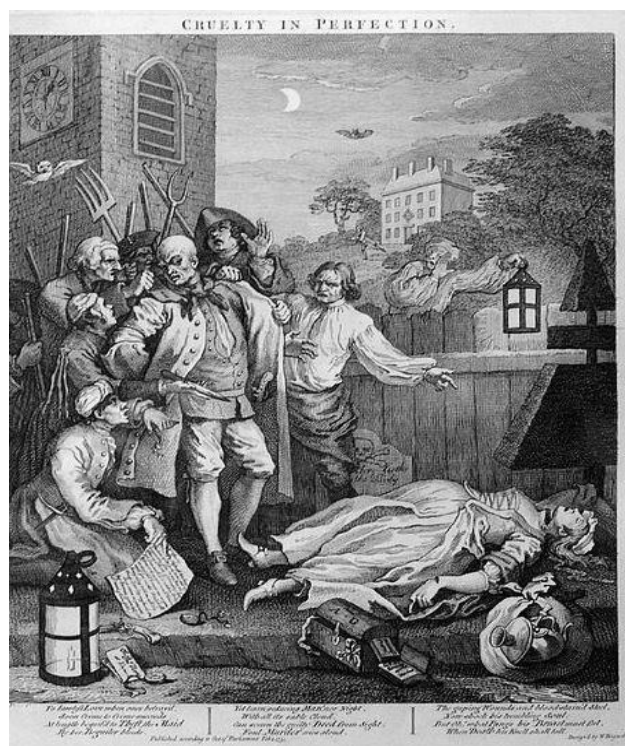

Figure 3. Cruelty in Perfection - 1751

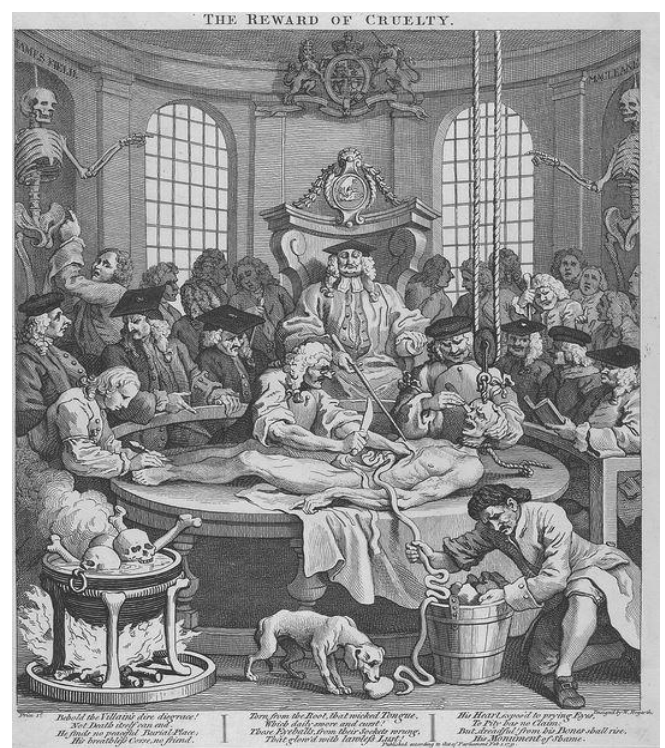

Figure 4. Reward of Cruelty - 1751

\section{Animal Cruelty as Conventional Wisdom}

Before exploring Hogarth's satiric intent, it is prudent to examine the animal cruelty claim. Scrutiny reveals multiple weaknesses, and the series has been little regarded by scholars. Charles Lamb wrote; "the Stages of Cruelty I omit, as mere worthless caricaturas, foreign to his general habits, the offspring of his fancy in some wayward humour" ${ }^{\prime \prime}$. The art historian Allan Cunningham expressed his negative view: "I wish it had never been painted. There is indeed great skill in the grouping, and profound knowledge of character; but the whole effect is gross, brutal and revolting. A savage boy grows into a savage man, and concludes a career of cruelty and outrage by an atrocious murder, for which he is hanged and dissected." ${ }^{5}$ Recent opinion echoes that, James Steintrager writing,

The story told in the series is almost banal in its clarity: a poor boy, Tom Nero, begins by torturing animals, eventually moves on to killing a human, and ends up an unwilling participant in an anatomy lesson ... It seems improbable that any reader of the series could not make sense of it. ... In actuality, the series projects a semblance of legibility for us to the extent that

4. C. Lamb, "On the Genius and Character of Hogarth ...," The Reflector, vol. 2. (London: Hunt, 1811), 74.

5. A. Cunningham, "William Hogarth": The Lives of the Most Eminent British Painters and Sculptors (London: Murray, 1830), 140-41. 
the values of sympathy and of non-cruelty to animals are shared (or at least acknowledged as prevalent) in many parts of the world. ${ }^{6}$

That focus on animal cruelty leaves unanswered many important questions. Why did Hogarth himself say of Steintrager's "almost banal" series, "If they have had this effect, and checked the progress of cruelty, I am more proud of having been the author, than I should be of having painted Raphael's Cartoons"? ${ }^{7}$ Surely other series should have made Hogarth more proud than one described by Lamb as "mere worthless caricaturas". In contrast to "worthless caricaturas" Cunningham refers to a "profound knowledge of character". How can those two statements be reconciled? Who then is depicted?

Why is Four Stages of Cruelty the only series depicted in both woodcuts and engravings? Why do commentators claim cheaper to make woodcuts were more costly than engraved copper plates? What was the contemporary legacy, if any, of the satire? Is there more to the series than meets a casual eye? Is it a thin veneer covering a hidden message for more discerning viewers? As a decorative mahogany veneer stretched over a strong oak carcass, or as one-seventh of a visible iceberg, with the dangerous six-sevenths hidden underwater? Animal cruelty has not identified those depicted, nor explained Hogarth's puns, his Biblical and Classical references, nor fitted the prints into the social, political and literary framework of the times.

The perception of the series as a Sermon became codified in the late eighteenth century. A Sermon was directed at uneducated people, and characterised by simple messages with obvious morality and Biblical references. In contrast a Satire is directed at the educated and uses humour, irony, exaggeration, ridicule or sarcasm to expose and criticise people's stupidity or vices, particularly in the context of contemporary politics and topical issues. In 1751 Christopher Smart's Mary Midnight highlighted the difficulty faced by readers then and now: "One Man prints a Sermon, which may as well be called a Satire ... Our Poetry is all Prose, and our Prose is false English". ${ }^{8}$

Those espousing animal cruelty underestimate Hogarth's artistic genius in pioneering the skill of political cartoonists, conveying a clear likeness with quick lines, and focusing on key physical characteristics. Hogarth chose to exaggerate animal cruelty in order to expose public apathy, and a neglect to censure or punish cruelty to women and infants. Acceptance of Four Stages of Cruelty as a satire is seen in the writings of Smollett, and in Henry Fielding's clever double entendre embracing Beer Street and Four Stages of Cruelty: “The ingenious Hogarth

6. J. A. Steintrager, Cruel Delight: Enlightenment Culture and the Inhuman (Bloomington: Indiana, 2004), 38-40, 50.

7. J. B. Nichols, Anecdotes of William Hogarth (London: Nichols, 1833), 65.

8. C. Smart, The Midwife, or, The Old Woman's Magazine, vol. 2 (London: Carnan), 1751, 116. 
hath very finely satyriz'd this, by representing several of the most valuable Productions of these Times on the Way to the Trunk-maker". ${ }^{9}$ Hogarth's exaggeration was noted in 1785: "The thrusting an arrow up the fundament of a dog, is not an idea of English growth. No man ever beheld the same act of cruelty practised on any animal in London". ${ }^{10}$

\section{The Front Door Key}

As a formally trained artist, Hogarth recognised the importance of iconographic symbolism in composing works of art, with Four Stages of Cruelty including embedded symbolic vignettes. The word vignette derives from little vine, especially with reference to the vine motif frequently used in embellishments to a text. Four Stages of Cruelty comprises central images surrounded by multiple vignettes winding vine-like back to the centre, each with a hidden message. Examples of his puns illustrate that Hogarth's satire is far more a carefully structured cryptic crossword, than an assemblage of social commentary, with the arrow important as a triple obstetric pun, or as a quadruple pun after first implying animal cruelty.

Hogarth's second use of the arrow, along with a bow leaning against the wall, was as symbol of Diana, Goddess both of Hunting and of Childbirth. Diana with her bow and arrow is one of the most readily recognisable images in classical art. Here, at first glance that does not help with interpretation of the image, but clarity dawns when linked to the dog. The reference to Diana signifies Hogarth intended the dog, not as male but as female; with the arrow not thrust into its anus, but into its vagina.

Hogarth's third pun emerges in considering who could take such cruel action. The arrow resembles an obstetric instrument used by man-midwives during difficult deliveries if the skull of a fetus needed perforating and extraction (Figures. 5-6). ${ }^{11}$ Hogarth, left on Figure 5, is seen with the prominent London man-midwives of 1750, William Smellie and William Hunter, whose actions predominate in this essay. Later analysis confirms the uncouth, "smelly", boy as Smellie, and the boy with a "hunter's" tricorne as Hunter. Fierce competitors, they "fight like cats" to insert the arrow.

9. H. Fielding, The Covent-Garden Journal, vol. 1. ed. G. Jensen (New Haven: Yale, 1915), 169.

10. J. Nichols, Biographical Anecdotes of William Hogarth, 3rd ed. (London: Nichols, 1785), 317.

11. J. Burton, An Essay Towards a Complete New System of Midwifery (Hodges, 1751). 


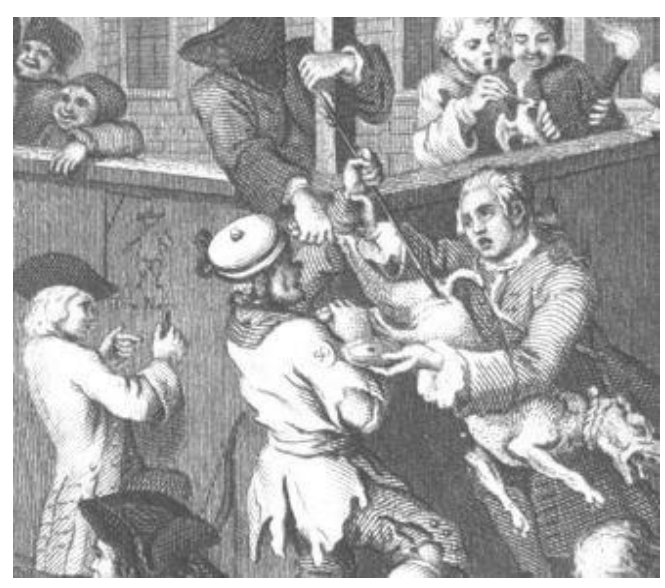

Figure 5. Arrow, and a Bow Against the Wall

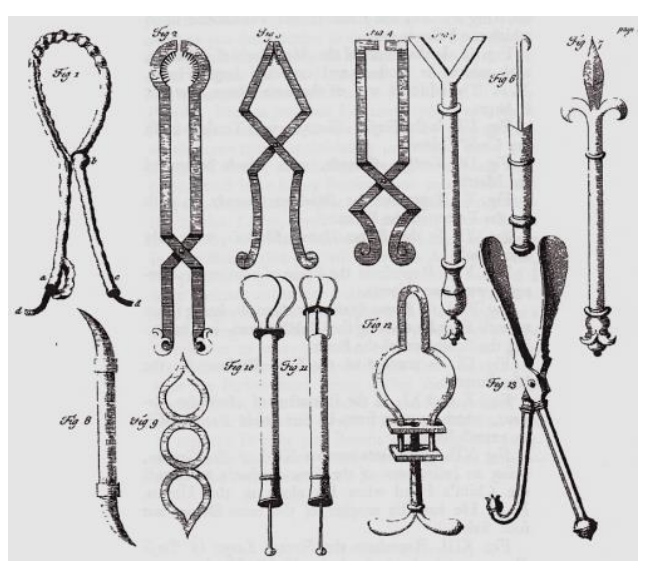

Figure 6. Obstetric Insruments c.1753

The third boy is William Hunter's younger brother, John Hunter, offering a tart, not as a cake, but as a prostitute; where "all" in the verse "take all my tart" offers a pregnant prostitute as substitute for the dog. This is an early use of "tart" as prostitute, as most dictionaries record a nineteenth century origin. But extensive innuendoes refer to a "cream tart" (a "tart" filled with "cream") in The Works of Moliere. ${ }^{12}$ In 1735 it was noted of the Greek philosopher, Bion (c.325-c.250 BC): "Bion said that unless one was a tart, or Thasian wine, it was impossible to please several persons ... Perhaps Bion, says he, pretended to speak of a tart that was hot and cold at the same time". ${ }^{13}$ In 1752 Henry Fielding penned his own innuendo on tarts and 'bastards': "But what Concern must the Author himself feel on such an Occasion; when he beholds those Writings, which were calculated to support the glorious Cause of Disaffection or Infidelity, humbled to the ignoble Purpose of supporting a Tart or a Custard!"14

Hogarth's fourth use of the arrow as a pun alludes to Smellie and the "Hunter" brothers; the arrow symbolising their use of obstetric instruments in "hunting" fetuses. Abortions were illegal, but those willing to secretly pay manmidwives, or certain midwives, could procure one. Intervention in difficult deliveries was accepted as necessary, so neither that, nor illegal abortions was serious enough to prompt Hogarth into publishing Four Stages of Cruelty. But a "quintuple" pun, the "angle" of flight of the arrow, reveals his intended target. If The First Stage of Cruelty is laid four-square on top of Cruelty in Perfection, the arrow's "angle" points directly at the pregnant womb of the murdered woman.

12. J-B. Poquelin, The Works of Moliere, French and English, vol. 3 (London: Watts, 1739), 307.

13. J. Bernard, A General Dictionary, vol. III (London: Strahan, 1735), 356.

14. H. Fielding, The Covent-Garden Journal, vol. 1. ed. G. Jensen (New Haven: Yale, 1915), 169. 
Her pregnancy and the pun on her name, "Ann Gill", confirm her as the "point" of Hogarth's "angle" in the satire.

One vignette in The First Stage of Cruelty, two boys with roosters and another "cocking" (readying) a stick, alludes to strict and detailed Rules and Orders for Cocking (cock-fighting) recorded in 1752. They included Rule I, "That every man having Cocks to fight, shew them and put them into the Pit with a fair Hackle, not too near shorn or cut, or any other Fraud, under pain of forfeiting ... Three Shillings and Four Pence", and Rule XVII, "That none shall strike or draw Weapon to strike any Man upon pain for every time so offending to forfeit Forty Shillings", with Rule XIX stating that half of all such forfeits be distributed to the poor of the parish. ${ }^{15}$

Hogarth draws attention to those strict rules of behaviour and fairness protecting fighting cocks as a "striking" contrast to man-midwives unregulated use of cruel obstetric "weapons" on parturient women; where any deliberate and/or negligent, patient injury and/or death was not subject to investigation, and went unpunished. They reveal Hogarth focussing on the mistreatment and murder of pregnant women by man-midwives in conducting obstetric experiments. Animal cruelty is but thin camouflage for his prime message; a threat to Smellie and Hunter of public exposure, potentially with trial and execution, unless they cease.

\section{The Need for a Rigorous "CSI" Style Methodology}

For many observers Four Stages of Cruelty has resembled a locked puzzle box; lacking an obvious key, decorated top and bottom with woodcuts, and on the four sides with engravings. Accorded a cursory glance, pigeon-holed, and passed over in favour of discussion of more titillating Hogarth series; particularly those focused on human foibles, frailties, and failings. That has resulted in Four Stages of Cruelty being read as a Sermon for 250 years, instead of a Satire; even though Hogarth placed a "front door" key in full view. This essay does not claim entry to the satire by using the "front door" key, instead the research entered with a "back door" key; a sudden and serendipitous realisation William Hunter's profile featured in The Reward of Cruelty. Followed by countless iterations, and references to social history.

Other Hogarth series have been treated to the proverbial "fine toothedcomb" seeking meanings hidden within the prints. An example is Fiona Haslam's discussion of The Company of Undertakers where she discusses heraldic allusions in detail. ${ }^{16}$ In contrast Four Stages of Cruelty appears bare of a quest for satire,

15. R. Heber, An Historical List of Horse-Matches Run and of Plates and Prizes (London: Heber, 1752), 149-54.

16. F. Haslam, From Hogarth to Rowlandson (Liverpool: Liverpool University, 1996). 
although several scholars have indicated a belief something remained hidden. As when Roy Porter hinted: "So upon what is the President-or Hogarth-sitting in judgement: the felon or the business of anatomy? And what precisely is there to choose, this moral twist invites us to ponder, between murderous malefactors and dissecting doctors?"17 And Ronald Paulson's comment: "Whatever ultimately disruptive elements may lurk in these prints". ${ }^{18}$ This essay seeks answers by unravelling puns, identifying those depicted, and weaving the prints tightly into issues of the day.

Full and logical analysis requires a methodical crime-scene-like investigation, to address all unanswered questions implicit in the theory of animal cruelty. The investigation needs to determine Hogarth's "motive", his "means", and his "opportunity". Conclusions must be supported by a framework explaining changes from his preliminary drawings, with any and all puns explained. The essay details the social factors and environment prompting Hogarth's "motive". It discusses the unethical medical practices creating an "opportunity" to address his concern. Analysis of his "method" shows the series as a pun-illustrated satire; threatening man-midwives with exposure unless they cease obstetric experiments. In ensuring the conclusions are robust, the essay stress-tests the framework in three ways. Firstly, against Hogarth's preliminary drawings. Secondly, against the April 1751, A Dissertation on Mr. Hogarth's Six Prints. ${ }^{19}$ Thirdly, by integrating the satire into the 1751-52 Paper War.

\section{Unwanted Infants - Life or Death? - the Foundling Hospital or Hunter's Anatomy School?}

Hogarth drew attention to social issues with engravings paralleling the literary satire of Jonathan Swift. In 1732 Hogarth demonstrated concern for the fate of prostitutes in The Harlot's Progress; that followed Swift's A Modest Proposal of 1729 , which offered a solution to unwanted children: "I have been assured by a very knowing American of my acquaintance in London, that a young healthy child well nursed is at a year old a most delicious, nourishing, and wholesome food, whether stewed, roasted, baked, or boiled".20 Another concerned was Daniel Defoe, his 1729 Augusta Triumphans promoted establishment of a foundling hospital, in a belief mothers were acquitted of infanticide by paying for expert witnesses.

17. R. Porter, Bodies Politic: Disease, Death, and Doctors in Britain, 1650-1900 (London: Reaktion, 2001), 50.

18. R. Paulson, Hogarth, His Life, Art, and Times, vol. 2 (New Haven: Yale, 1971), 109.

19. T. Smollett, A Dissertation on Mr Hogarth's Six Prints ... (London: Dickinson, 1751).

20. J. Swift, A Modest Proposal .... (Dublin: Bickerton, 1729), 10. 
Hogarth shared these concerns as a Foundling Hospital governor from its 1739 establishment by Captain Thomas Coram, who was horrified at abandoned children in the streets. The casual culling of unwanted pregnancies and infants, so distressing to Swift, Defoe, Coram, and Hogarth, was accepted by society with few prosecutions. Typical was Hannah Perfect, a servant tried on 25 February 1747 for killing her new-born baby in a house where no-one knew she was pregnant. Hannah was prosecuted under a law of 1624, being an Act to Prevent the Destroying and Murdering of Bastard Children. She was acquitted, but pregnant servants were common. When Coram opened the Hospital it was overwhelmed by the response from mothers and started a ballot system. Mothers picked a ball from a bag to decide the fate of their child, while wealthy women looked on as if it were a spectator activity. On 30 March 1754, only 20 children out of 100 were admitted by lot into the hospital. Hence the Hospital was only a partial solution to unwanted pregnancies; abandonment and infanticide continued. In this intensely antisocial climate William Hunter opened his anatomy school on 13 October 1746 and, from its opening, abandoned infants arrived there dead, and sometimes alive, as subjects for dissection. Hunter recommended his students procure multiple bodies of children for dissection and study:

The dead body cannot be too fresh for dissection; every hour that it is kept, it is losing something of its fitness for anatomical demonstrations; the blood is transuding, and bringing all the parts nearer to one colour, which takes off the natural and distinct appearance; and putrefaction is advancing, which makes all the fleshy parts tender and indistinct. ... every student [must] make and collect as many anatomical preparations as he can. ... He should have a preparation of all the blood vessels in their natural situation, and two preparations of the trunk of a child, the one presenting a fore view, the other a back view, of the whole viscera, and as many preparations of the organs of sense and generation, and of the particular viscera as he can easily procure. ${ }^{21}$

The opening of Hunter's school exacerbated the demand for subjects of all ages for dissection, and prompted a letter in the Westminster Journal on 19 November 1746, drawing attention to the urgent need for more fresh bodies for dissection, hinting at murders-for-dissection, and proposing a law change. The letter has since been attributed to writer Tobias Smollett, on behalf of his friend William Hunter:

I am informed that it is absolutely necessary for every lecturer to be furnished with at least one fresh body once a week; and that it would be much more for the advantage of the pupils who attend, to have two or three

21. W. Hunter, Two Introductory Lectures, Delivered by Dr. William Hunter (London: Johnson, 1784), 87, 110. 
bodies at the same time under dissection. We are sure that they have not all these bodies from Tyburn, and we do not know that they are allowed any from the hospitals ... The way for relief lies in the favourable interposition of Parliament by adding a clause to some Bill in the Present session, that from henceforth every felon that shall be hanged at Tyburn shall be carried from thence to Surgeons' Hall, and there by proper persons, be distributed among those gentlemen who are reading Anatomical lectures. ${ }^{22}$

Predictably, the authorities took no action and anatomists continued with body-snatching and murder. As targets for murder were generally prostitutes, vagrants, and abandoned children, a blind eye was turned to body-snatching and murder-for-dissection, due to a need to train military surgeons. The letter was echoed a year later on 24 October 1747 in a polemic satire, likely also penned by Smollett:

I never think on the relation of the young lady, of Hatton Garden, whose body was taken away by the sexton, the very night of its interment, and sold to a surgeon, without heartily wishing the vile thief might he rewarded with the gallows and afterwards anatomised. I am informed that it is a common practice with these fellows, and their comrades, to steal dead bodies and sell them, which I fear is too true, since, otherwise, the surgeons would never have such plenty of dissections. If there is no law in being for punishing offenders of this kind with death, it is high time that there should be ... Secondly, That all physicians, men and women midwives (for I would not exclude any old woman of the faculty) surgeons, apothecaries, quacks, toothdrawers, their pupils, journey-men, apprentices and labourers, shall, as soon as they are dead, be carried to the [Surgeons'] hall and there dissected. ${ }^{23}$

In his lectures, Hunter admitted illegal procurement of bodies by murder and/or grave-robbing, but stressed a need for the tightest secrecy about his dissections and, especially, experiments involving the pregnant gravid uterus:

In a country where liberty disposes the people to licentiousness and outrage, and where Anatomists are not legally supplied with dead bodies, particular care should be taken, to avoid given offence to the populace, or to the prejudices of our neighbours. Therefore it is to be hoped, that you will be upon your guard; and, out of doors, speak with caution of what may be passing here, especially with respect to dead bodies. These considerations render it necessary to shut our doors against strangers, or such people, as might chuse to visit us, from an idle, or even malevolent curiosity. But, if a

22. G. Peachey, A Memoir of William \& John Hunter (Plymouth: Peachey, 1924), 95.

23. Anon (Smollett?). The Gentleman's Magazine, vol. 17 (London: Cave, 1747), 487. 
student should wish to introduce a friend to any particular lecture, it will give us pleasure to oblige him; provided he will only take the trouble of presenting his friend, just before the lecture begins. The lectures, however upon organs of generation; and gravid uterus, are to be excepted. No visitor can be introduced when we are upon these subjects. ${ }^{24}$

In 1758 Samuel Johnson conveyed his own extreme contempt for anatomists:

Among the inferior professors of medical knowledge, is a race of wretches, whose lives are only varied by varieties of cruelty; whose favourite amusement is to nail dogs to tables and open them alive; to try how long life may be continued in various degrees of mutilation ... the anatomical novice tears out the living bowels of an animal and stiles himself Physician, prepares himself by familiar cruelty for that profession which he is to exercise upon the tender and the helpless, upon feeble bodies and broken minds, and by which he has opportunities to extend his arts of torture, and continue those experiments upon infancy and age, which he has hitherto tried upon cats and dogs. ${ }^{25}$

Subjects for anatomists included kidnapped children, as reported on 14 August 1754: "Last Sunday two children were stolen from Windmill Street, and two out of Red-lion Square; and yesterday they were found at a house in Tyburn Road in custody of four women, who had stripped them almost naked" ${ }^{26}$ Windmill Street was only a half mile from Hunter's anatomy school in Covent Garden and he later lived and maintained his school in Windmill Street. The incident implies kidnapped or unwanted infants were assembled prior to his lectures, to be fresh subjects for dissection; as suggested by a 1762 report from near Tyburn Road: "Yesterday morning about four o'clock a man going to take up a load of dung from a dunghill in St George's Fields; near the New-Inn, to his great surprize found the bodies of a woman and eight children cut and mangled in a shocking manner; the upper part of the woman's body to her navel was cut off; and likewise her legs, and what remained much mangled, as were the bodies of the children. The bodies could not have been long there, as they were no way tainted". ${ }^{27}$

The foundling situation was not improved in 1756, when Parliament resolved all children offered to the Foundling Hospital should be received. A basket was hung outside the hospital, the maximum age for admission was raised from two

24. W. Hunter, Two Introductory Lectures, Delivered by Dr. William Hunter (London: Johnson, 1784), 113.

25. S. Johnson, The Idler in The Gentleman's Magazine, vol. 28 (London: Cave, 1758), 365.

26. Anon, The Universal Magazine, vol. 15, (London: Hinton, 1754), 92.

27. Anon, The London Chronicle, vol. 12 (London: J. Wilkie, 1762), 54. 
to twelve months, and a flood of children arrived. In less than four years nearly 15,000 children were presented to the hospital, and a trade grew up with "Coram Men", promising to carry children from the country to the hospital, but secretly supplying Hunter's anatomy school. In 1760 midwife and author Elizabeth Nihell lamented the fate of poor-house children sold by parish officials to anatomists. Her reference to "fourteen" years prior to 1760 implicitly accused Hunter of dissections at his anatomy school from its 1746 opening, with "twenty" years alluding to Smellie's actions from 1740;

[One] needs but to examine [parish records] to discover the red-letter catalogues of the armies of innocents ... put to death under the management of the charity destined to preserve their life. There will be found not one but many, even of the most populous parishes, where for fourteen, twenty, or more years, not one poor babe of the thousands taken in have escaped the general destruction, and sacrifice to that inhuman fiend of Hell ... Will any one here say, that this total mortality was purely accidental? ... What could be so intolerable in the sum to be added, to that actually paid for their being worse than murdered out of hand, to save their little lives, and bring them up..$^{28}$

\section{Obstetric Experiments by Smellie and Hunter}

Originally a navy surgeon inured to injury and death, Smellie became a country practitioner in Scotland, then in 1738 went to Paris to attend lectures on midwifery, before returning to London to teach midwifery. As one of his initiatives, he facilitated his teaching by setting up a lying-in fund for indigent patients, many being pregnant prostitutes, on the condition they allow his students to observe them during late pregnancy and birth, in 1742 advertising: "He has houses where poor women with child are delivered, at which deliveries those who are his pupils may, on reasonable terms, be present" ${ }^{\prime 2}$ Lying-in houses represented a ready supply of vulnerable pregnant women. Difficult deliveries rarely needed forceps, but Smellie conducted trials with varying styles of forceps on many indigent women whose condition did not necessitate forceps deliveries. It being easy to tell a patient in painful labour forceps were necessary, even when not, and with little fear of detection. Some patients died and others suffered internal damage.

In 1748 Smellie was accused: "I have been told of no less than Eight Women who have died within these last few Months under the hand of a Wooden

28. E. Nihell, A Treatise on the Art of Midwifery (London: Morley, 1760), 196-98.

29. S. Seligman, "The Royal Maternity Charity: The First Hundred Years," Med Hist. 24, no. 4(1980): 403-18. 
Operator. Now, Sir, it is very plain that the Allusion is to the General Practice of that Operator, and not confined to the Forceps only" ${ }^{30}$ And in 1753 John Burton charged Smellie with dangerous practices, "Smellie uses the Forceps in Cases that don't require it, and thereby increases the Dangers to both Mother and Child". ${ }^{31}$ Burton was critical of Smellie's excessive use of a crotchet to terminate pregnancies by killing and extracting the fetus. In contrast to Smellie, when Frank Nicholls accused the Lying-in Hospital of malpractice, the hospital quoted from their records; 545 women delivered 550 babies between November 1749 and January 1752, but only two required the use of instruments. ${ }^{32}$

William Hunter also came to London from Scotland, initially as apprentice to Smellie, before studying in Paris, then competing as a man-midwife. After establishing his own anatomy school in 1746, Hunter was a founder of the [British] Lying-in Hospital in Brownlow Street in November 1749, as one of two man-midwives on call. When established it was the only hospital in England solely employed for lying-in women, but only for those married; the hospital rules included:

The Committee decreed that women should be received in the last month of their pregnancy on a letter of recommendation from a subscriber and on producing an affidavit of their marriage ... In 1751 a patient, Ann Poole was summarily dismissed from hospital because she was unmarried and had falsely sworn on affidavit she had been married in the Fleet [prison] and had been subsequently deserted. Her defence that 'necessity obliged her to crave the aid of charity' was of no avail. ${ }^{33}$

The hospital rules show the bleak situation for unmarried pregnant women, who turned in desperation to the free service offered by Smellie. One can speculate a reason for lying-in hospitals to refuse unwed women was to ensure Smellie, Hunter, and other man-midwives retained a steady stream of indigent parturient women, thereby forced to become teaching subjects. Smellie and his assistants, Colin Mackenzie, also a Scottish ex-navy surgeon and John Harvie, competed with the Hunters for students, in seeking obstetric discoveries at a time gravid uterus knowledge was subject to vigorous debate; as unclaimed, undelivered subjects for dissection were impossibly rare. Wide variance of opinion still prevailed when Exton wrote in 1751, "Anatomists have varied very much in their opinions concerning the substance of the womb during

30. W. Douglas, (likely Smollett) A Letter to Dr Smelle, ... (London: Roberts, 1748), 10.

31. J. Burton, A Letter to William Smellie MD, .... (London: Owen, 1753), vi.

32. J Cook and B. Cook, Man-midwife, Male Feminist.... (Ann Arbor: University of Michigan, 2004), 118.

33. C. Vartan, “The Lying-in Hospital 1747", Proc R Soc Med. 65, no 5(1972): 467. 
pregnancy". ${ }^{34}$ Lack of consensus is seen in fetal images by John Burton ${ }^{35}$ and Donald Monro ${ }^{36}$; with a lack of direct observation evident compared to van Rymsdyk (Figures 7-10). ${ }^{3738}$

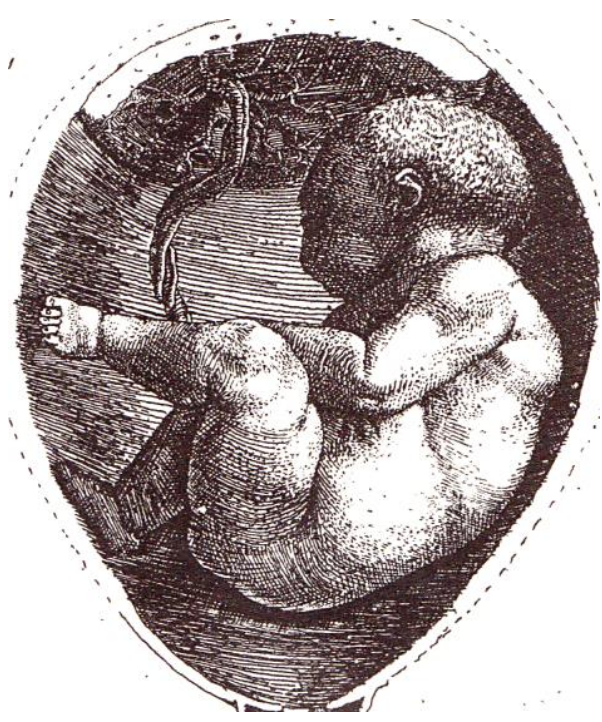

Figure 7. John Burton York 1751

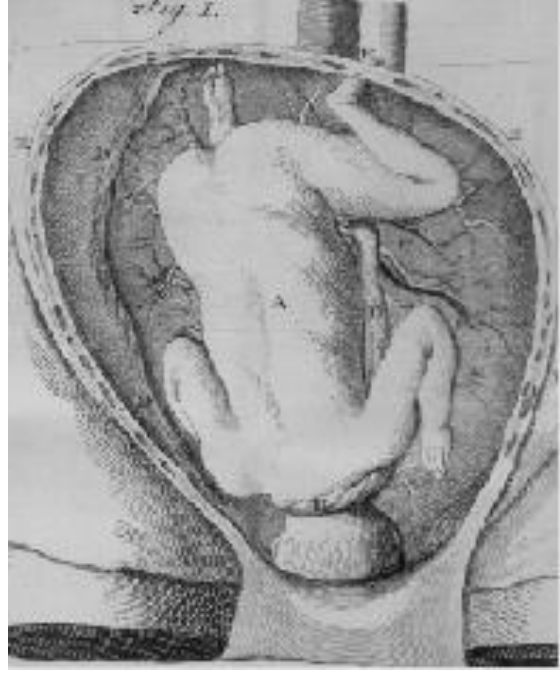

Figure 8. D. Munro Edinburgh 1753

Even before 1750 Smellie and Hunter had realised the catalyst for obstetric, as well as anatomical research, was access to fresh, healthy, subjects procured in articulo mortis, at the point of death, rather than decaying corpses dead of disease or old age. Smellie demonstrated on female cadavers, as well as machines, during his midwifery lectures. He and Hunter abandoned any pretence at ethics when comments by Jean Louis Petit, Director of the French Royal Academy, were published in London in 1750: "An anatomist who has only dissected men, is not in a condition to operate equally safely on women, when they labour under disorders of the parts which distinguish their sex. In order to be sure of our procedure, we must have dissected women who have died both before and after delivery". 39

34. B. Exton, A New and General System of Midwifery (London: Owen, 1751), 123.

35. J. Burton, An Essay Towards a Complete New System of Midwifery (Hodges, 1751), 196.

36. D. Monro, "The Dissection of a Woman with Child", Essays and Observations, vol. 1 (Edinburgh, Hamilton, 1754).

37. W. Smellie, A Sett of Anatomical Tables with Explanations ... (London: Freeman, 1754).

38. W. Hunter, The Anatomy of the Human Gravid Uterus (Birmingham: Baskerville, 1774).

39. J. Petit, "Remarks on various faulty conformations of the Anus in new born Children", ed. M de la Peyronie, Memoires of the Royal Academy of Surgery. vol. 1 (London: Cave, 1750), 247. 


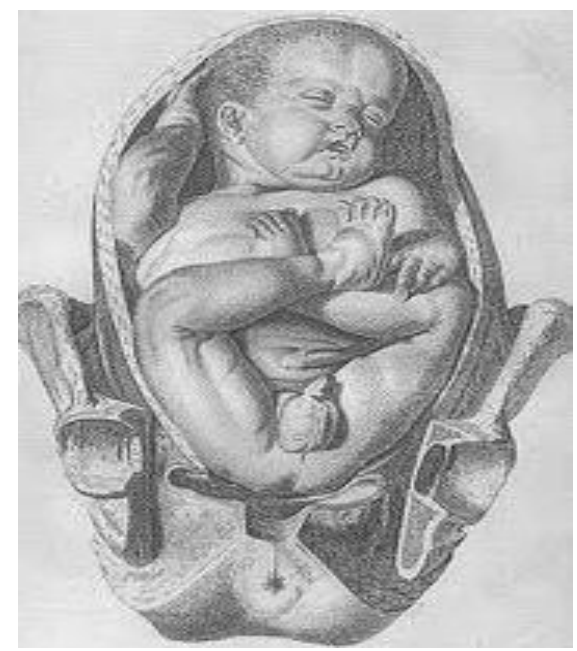

Figure 9.Van Rymsdyk - Smellie

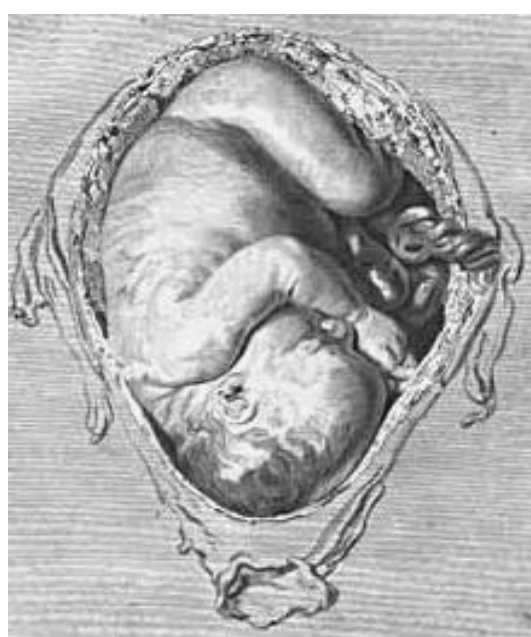

Figure 10. Van Rymsdyk Hunter 1750

This was a spur to Smellie and Hunter, but to seek pregnant subjects resurrected from graves was pointless as they were so rare. Annual undelivered deaths in London were in low single figures, and even then deceased mothers were badly damaged during attempts to save the baby. Smellie resorted to murder-for-dissection of indigent patients, particularly country girls who had come to London and become pregnant. This was not as risky as it seems, if a friend enquired they were simply told the mother had died in childbirth. With the corpse immediately dissected this could not be disproved. The method of murder is relevant to Four Stages of Cruelty. In 1737 the anatomist Alexander Monro extolled a need for freshness, at a time human subjects were described as creatures or animals. Monro implied fresh human subjects, bled to death, were preferred for successful injection of wax into veins and arteries:

The younger the creature to be injected is, the injection will ceteris paribus, go farthest, and vice versa. The more the creature's fluids have been dissolved and exhausted in life [bled to death], the success of the operation will be greater. The less solid the part designed to be injected is, the more vessels will be filled. The more membranous and transparent parts are, the injection shows better. Whereas in the solid very hard parts of a rigid old creature, that has died with its vessels full of thick strong blood, it is scarce possible to inject great numbers of small vessels. ${ }^{40}$

Murder of subjects by bleeding to death still prevailed in nineteenth-century New York: "I recollect one of the stories then prevalent, and universally believed, that missing children had been found in the haunts of the burkers in our city,

40. A. Monro, Medical Essays, vol. 1 (Edinburgh: Monro, 1737), 105. 
fastened in a sitting position in a chair, with their feet immersed in warm water, an important artery cut, and slowly bleeding to death." 41

To provide a lasting record, and sell copies for profit, in 1750 Smellie hired the talented Dutch artist Jan van Rymsdyk to make forensic quality drawings of his obstetric research for a proposed anatomical atlas. The drawings were exact drawings from "life", i.e. "death", being subjects murdered during labour, including a series to progressively show how the head of a fetus turned in passing though the birth canal. Smellie next decided to seek a successful procedure for Caesarean births; to substitute for termination of fetuses via a craniotomy. Smellie believed whoever first documented how to perform a Caesarean would make his fame and fortune. To do so he needed to experiment where best to make an incision, but a Caesarean obviously necessitated the pregnant mother be alive when the experiment commenced. Smellie had "persuaded" indigent women in painful labour forceps were "necessary", but this was impractical for Caesareans. He decided to perform secret Caesarean experiments on indigent patients, with the mothers murdered during the operation to prevent them informing of the experiments. Smellie's experiments became known to Hunter after van Rymsdyk realised encouraging Hunter to compete would generate more artwork.

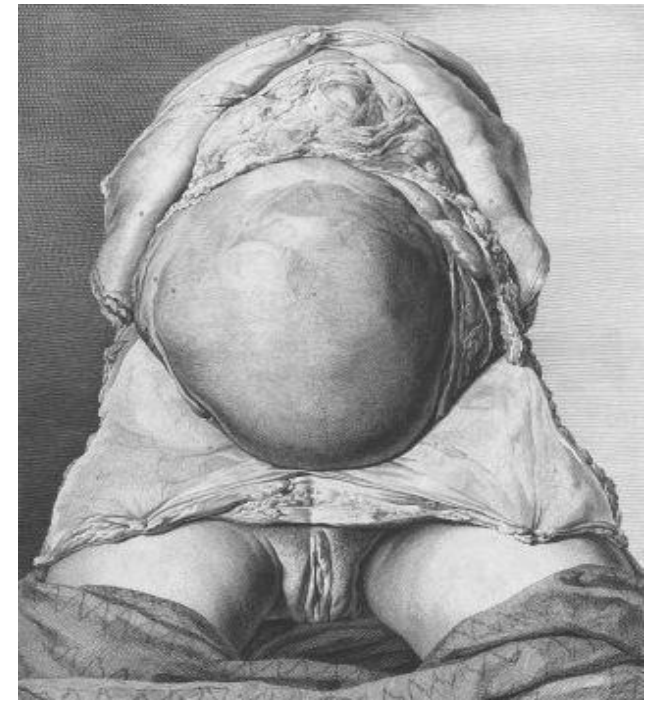

Figure 11. Hunter's Atlas - Table IV

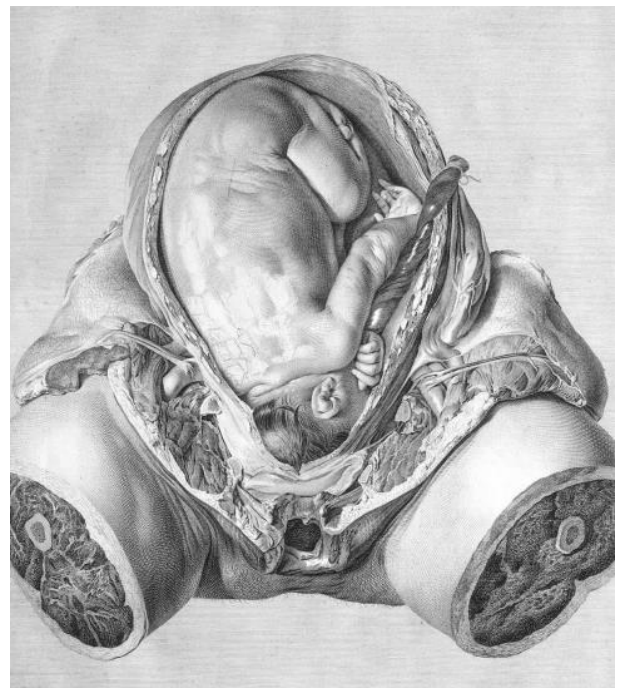

Figure 12. Hunter's Atlas - Table VI

Hogarth learned of the obstetric experiments during a visit to Hunter's anatomy school. Events suggest his visit was in December 1750, with Hunter writing: "You cannot conceive anything lying snugger than the foetus in utero. This puts me in mind of Hogarth. He came to me when I had a gravid uterus to open and was amazingly pleased. Good God, cries he, how snug and compleat

41. J. Mines, A Tour Around New York (New York: Harpers, 1892), 143. 
the child lies. I defy all our painters in St. Martin's Lane to put a Child in such a situation. He had a good eye, took it off and in drawing afterwards very well expressed it". 42

Hogarth's own drawing has not survived, likely destroyed after learning Hunter was murdering parturient patients; lest he, Hogarth, be deemed a collaborator. The dissection of a pregnant victim viewed by Hogarth was almost certainly the torso depicted in Figures. 11-12; with the head and limbs removed, and transferred to Hunter's school for separate student dissection. Hunter may have invited Hogarth to view the gravid uterus, to ask if the Foundling Hospital would accept babies surviving from any of his Caesarean experiments. Such babies would be living proof of Hunter's success, help advertise his lectures, and be anatomical wonders of the age. As a Foundling Hospital governor, Hogarth was stunned to learn the pregnant subject had been murdered; it roused him to urgently make woodcuts, to reinforce his demand that Hunter cease experiments.

The callous eighteenth century attitude of anatomists to pregnant prostitutes is revealed in a remarkable letter of 18 April 1768 from John Cook, with its timing and intent closely connected to the Hunters. Two sons of Cook, George likely a student under Hunter in c.1755 and Lemuel in c.1764, were positioned to be aware of Hunter's obstetric research. Cook's letter, discussing compulsory extraction of live children from prostitutes by Caesarean, was written 18 months before John Hunter assisted with the first "reported" Caesarean in England, but the wording implies prior successful experiments involving babies saved from murdered mothers. It illustrates the insensitivity of eighteenth-century experimental anatomists:

Reason and example prove that the foetus in utero has its own distinct life; and experience teaches, that although the mother be dead, the child may frequently live several hours in the womb. The extraction and preservation of children by the Cæsarian operation, timely performed, after the decease [euphemism for murder] of the mother proves the same. ... And if prostitutes are punished, as an example to others, who destroy the fruit of their body, born at a proper time ... the extraction of such children from the womb may easily be performed, and the infant thereby be happily snatched out of the jaws of death. ${ }^{43}$

Cook's letter amounted to a call for compulsory Caesareans on pregnant prostitutes, on the presumption they would deliberately kill their babies. The letter urged Caesarean research, and the more it is studied, the more one senses Hunter encouraged the letter, to sound out attitudes to a possible law change. Laws adopting Cook's proposal would have been a godsend for the Hunters; in

42. F. Haslam, From Hogarth to Rowlandson (Liverpool: Liverpool University, 1996), 218. 43. J. Cook, The London Magazine, vol. 37 (London: Baldwin, 1768), 301-02. 
providing them with an ongoing and legal supply of pregnant prostitutes to teach Caesareans to students, without risk of prosecution. Any readers shocked into disbelief that man-midwives undertook murder-for-dissection as nonconsenting Caesareans, are reminded the last woman burned at the stake was Catherine Murphy on 18 March 1789.

\section{Characterisation in Four Stages of Cruelty}

There has been debate as to whether Hogarth depicted real people in his prints. Intensely interested in people, far more than animals, he had an uncanny ability to depict real people: "The third scene of his Harlot's Progress introduced him to the notice of the great. At a board of Treasury which was held a day or two after the appearance of that print, a copy of it was shewn by one of the lords, as containing, among other excellencies, a striking likeness of Sir John Gonson." 44 Thomas Clerk cryptically wrote of Four Stages of Cruelty in 1812: "All the countenances in this print are strongly characteristic", but he did not elaborate. ${ }^{45}$ Clerk's words imply knowledge of those depicted but, even 60 years later, a reluctance to disclose identities. Inevitably, higher echelons of society tended to protect their friends; the Hunters were alive in 1782, when Horace Walpole conveyed his own wilful blindness:

It is to Hogarth's honour that in so many scenes of satire or ridicule, it is obvious that ill-nature did not guide his pencil. ... Except in the print of the Times, and the two portraits of Mr. Wilkes and Mr. Churchill that followed, no man, amidst such a profusion of characteristic faces, ever pretended to discover or charge him with the caricatura of a real person; except of such notorious characters as Chartres and mother Needham, and a very few more, who are acting officially and suitably to their professions. As he must have observed so carefully the operation of the passions on the countenance, it is even wonderful that he never, though without intention, delivered the very features of any identical person. It is at the same time a proof of his intimate intuition into nature: but had he been too severe, the humanity of endeavouring to root out cruelty to animals would atone for many satires. It is another proof that he drew all his stores from nature and the force of his own genius. ${ }^{46}$

In contrast, Henry Fielding implied Hogarth depicted "notorious characters" in Four Stages of Cruelty. Fielding's earlier quote regarding "a Tart or a Custard", 26.

44. J. Nichols, Biographical Anecdotes of William Hogarth, 2nd ed. (London: Nichols, 1782),

45. T. Clerk, The Works of William Hogarth (Edinburgh: Scholey, 1812), 179.

46. H. Walpole, Anecdotes of Painting in England, vol. 4 (London: Dodsley, 1782), 151. 
was part of a satire in Covent-Garden Journal criticising "Trunk-makers" and "Pastry Cooks"; epithets used as a means of insult among authors. Fielding's used an allusion to Four Stages of Cruelty to hide a satire targeting anatomists. References imply "Trunk-makers" as anatomists cutting off limbs in converting dead bodies to torsos, and "Pastry Cooks" as man-midwives taking buns out of the oven, i.e. hunting fetuses. Fielding's double entendre then emerges: “The ingenious Hogarth hath very finely satyriz'd this, by representing several of the most valuable Productions of these Times on the Way to the Trunk-maker"- an allusion to the "most valuable Productions", i.e. the Trunk-makers and Pastry Cooks themselves; Smellie and the Hunters, deserving to become "trunks", upon dissection by "trunk-makers". ${ }^{47}$ This prompted a defensive satire, probably by Smollett, on the fate of books; as a red-herring to divert attention from Fielding's message. It was a Literary Bill of Mortality for 1752, which recorded; Casualties Among Books: Abortive 7,000, Stillborn 3,000, Miscarriage 17, Complication 98, Found Dead 303, Trunk-makers 1,000, and Pastry Cooks 800.48

\section{The Woodcuts}

Four Stages of Cruelty is the only known example of Hogarth cutting woodcuts prior to engravings, Figures 13-14. Why was this? Scrutiny of the two woodcuts, Cruelty in Perfection and The Reward of Cruelty, is important to Hogarth's motive, and does not support cruelty to animals. Only two animals are depicted, neither being harmed; a flying bat in Perfection and, in Reward, a dog eating a human heart!

The Perfection woodcut is inscribed, "Inv'd and published by Wm. Hogarth, Jan 1, 1750, J. Bell sculp." (OS date). Early versions of the woodcuts are rare and it is uncertain when they were first issued for sale, probably not before Hogarth died. Some claim a change from woodcuts to engravings was due to excessive cost, but with two blocks already cut this is an obfuscation. Wood was cheaper to purchase than copper, and easier to work in creating an image, unlike the skill needed for a copper plate. Woodcuts were made quickly by a less skilled artisan, so cost less. To abandon two woodcuts based on cost, purports engraving four copper plates was cheaper than making two additional woodcuts. For Hogarth, well experienced in publishing, this makes no sense. He had a different and compelling reason for the woodcuts; a credible reason being a haste to prepare proofs, why the woodcuts lack title and verse.

47. H. Fielding, The Covent-Garden Journal, vol. 1. ed. G. Jensen (New Haven: Yale, 1915), $167-71$.

48. Anon, The Gentleman's Magazine, vol. 22 (London: Cave, 1752), 612. 


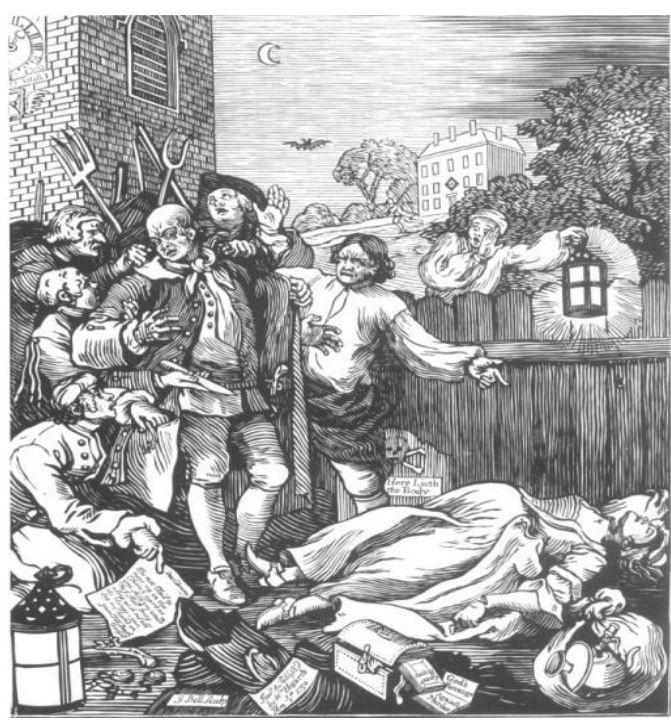

Figure 13. Cruelty in Perfection - 1750 woodcut

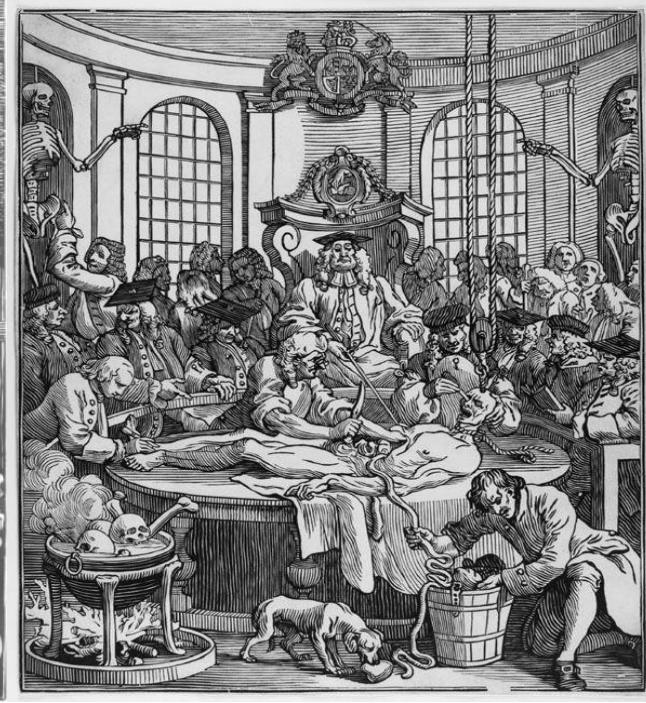

Figure 14. Reward of Cruelty - 1750

woodcut

Hogarth's urgency is explained in discussing the obstetric experiments conducted by Smellie and Hunter. The experiments coincided with magistrate Henry Fielding's efforts to reduce crime during a post-1748 crime wave, associated with demobbed soldiers after the Jacobite rebellion and peace in Europe. In 1749 Fielding published The History of Tom Jones, and established the first quasi-official detective policemen, known as the Bow Street runners: succeeded on his death in 1754 by his brother, blind John Fielding. Hogarth verbally challenged Hunter, but without bodies as evidence it was difficult to approach Fielding with an accusation of murder against Hunter. The evidence was gone, with the human remains fed to wild animals in John Hunter's menagerie. Frustrated, Hogarth opted to confront Hunter with woodcut proofs of Cruelty and Reward, and a threat of public exposure unless experiments ceased.

Hogarth was then completing The March to Finchley, whilst supervising Luke Sullivan in preparing a detailed engraving of The March for publishing, so he enlisted John Bell to prepare the woodcuts. Hogarth never explained the woodcuts, but they puzzled John Nichols who, seeking an explanation, in 1781 re-interpreted Hogarth's advertisement to propose: "These have been commended amongst the best prints of Mr. Hogarth. They are surely the most disgusting in the whole collection. Of the two latter of these there are wooden plates on a large scale, invented and published by W. Hogarth. They were executed by order of our artist, who wished to diffuse the salutary example they contain, as far as possible by putting them within the reach of the meanest purchaser." 49 In 1782 Nichols modified this to, "They were done by order of our artist who wished to diffuse the salutary example they contain, as far as possible,

49. J. Nichols, Biographical Anecdotes of William Hogarth, 1st ed (London: Nichols, 1781), 116. 
by putting them within the reach of the meanest purchaser; but finding this mode of executing his design was expensive beyond expectation, he proceeded no further in it, and was content to engrave them in his own coarse, but spirited manner. Impressions from the wooden block are to be had at Mrs. Hogarth's house in Leicester Fields." 50 Nichols had erroneously interpolated the advertisement, in opining the woodcuts were abandoned due to expense, a mistake repeated by later scholars. That impressions were noted as available from Mrs Hogarth in 1782, hints the woodcuts were not actually published for sale until long after Hogarth's 1764 death.

\section{The Engravings}

Complete re-cutting and re-issue of a print after one month is costly and rare. For engravings to then follow only a month later implies time was still of the essence. Perfection and Reward were re-engraved and issued, with The First Stage of Cruelty and The Second Stage of Cruelty as a set of four engravings dated 1 February 1751, only a month later. Confusingly for historians, this was a time of change in the commencement of a year. The full year 1750 ended on 24 March, followed by 1751, which was a short year of 282 days, running from 25 March to 31 December, with the full year 1752 beginning on 1 January. From the twentyfirst century it can be difficult to accept 31 December 1750 as the day before 1 January 1750 and so Hogarth anticipated the imminent change to 1751. The four engraved prints, with Beer Street and Gin Lane were advertised in the General Advertiser for 13 February 1750/51.

On Friday next will be published, price one shilling each. Two large Prints designed and etched by Mr. Hogarth, called Beer-street and Gin-lane. A number will be printed in a better manner for the Curious at 1s. 6d. Each. And on Thursday following will be published, Four Prints on the subject of Cruelty. Price and size the same. N.B. As the subjects of these Prints are calculated to reform some reigning vices peculiar to the lower class of people in hopes to render them of more extensive use, the author has published them in the cheapest manner possible. To be had at the Golden Head in Leicester Fields, where may be had all his other works. ${ }^{51}$

The advertisement excludes any reference to the woodcuts, referring instead to six engraved prints; a version in the "cheapest manner possible" for a shilling each, and another "printed in a better manner" for one shilling and sixpence.

50. J. Nichols, Biographical Anecdotes of William Hogarth, 2nd ed (London: Nichols, 1782), 316.

51. J. Nichols, Biographical Anecdotes of William Hogarth, 3rd ed (London: Nichols, 1785), 312. 
When analysed carefully, there is a satirical allusion to the series in Hogarth's autobiographical notes; first published in 1798 by John Ireland, and in 1833 reprinted by Nichols:

The leading points in these, as well as the two preceding prints [Beer Street and Gin Lane], were made as obvious as possible, in the hope that their tendency might be seen by men of the lowest rank. Neither minute accuracy of design, nor fine engraving, were deemed necessary, as the latter would render them too expensive for the persons to whom they were intended to be useful. And the fact is, that the passions may be more forcibly expressed by a strong bold stroke, than by the most delicate engraving. To expressing them as I felt them, I have paid the utmost attention, and as they were addressed to hard hearts, have rather preferred leaving them hard, and giving the effect, by a quick touch to rendering them languid and feeble by fine strokes and soft engraving ... The prints were engraved with the hope of in some degree correcting that barbarous treatment of animals, the very sight of which renders the streets of our metropolis so distressing to every feeling mind. If they have had this effect, and checked the progress of cruelty, I am more proud of having been the author, than I should be of having painted Raphael's Cartoons. ${ }^{52}$

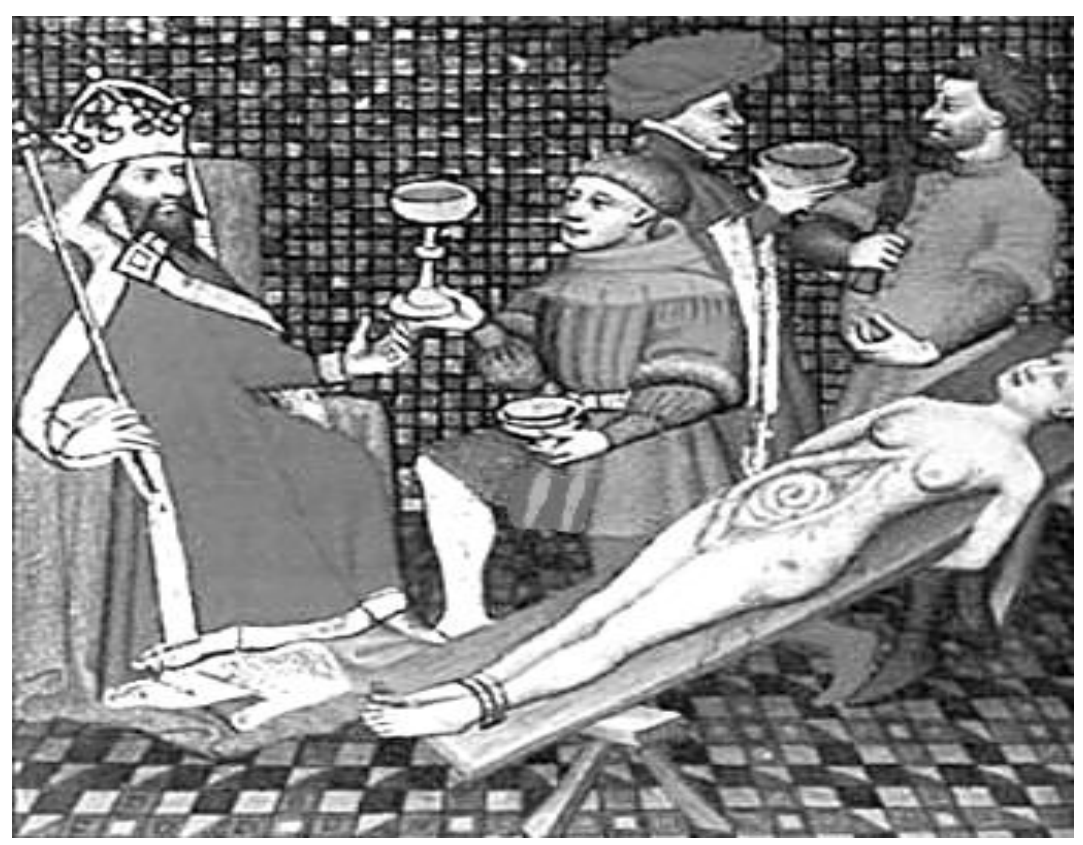

Figure 15. Miniature from Le Cas des Nobles et Femmes (c.1410), by Boccaccio, $B N F$

52. J B. Nichols, Anecdotes of William Hogarth (London: Nichols, 1833), 64. 
In the advertisement, Hogarth implicitly refers to six engravings, but not the woodcuts. Prima facie, the set of six refer to gin, and cruelty to innocent animals but, as a satire, are "addressed to hard hearts" of Smellie and Hunter; scorned as "men of the lowest rank". Hogarth's comment is consistent with the view that unpublished proofs of the woodcuts had been quickly printed to challenge Smellie and Hunter.

It helps to follow Hogarth's thought process; Perfection reveals Hogarth drawing on Emperor Nero's [hence Tommy Nero] reputed dissection of the womb of his live and restrained mother, Agrippina, to see whence he had come (figures. 15-17). Also prompted by Fielding's Preface to Joseph Andrews, "What could exceed the Absurdity of an Author, who should write the Comedy of Nero, with the merry Incident of ripping up his Mother's Belly, or what would give a greater Shock to Humanity, than an Attempt to expose the Miseries of Poverty and Distress to Ridicule?" 53

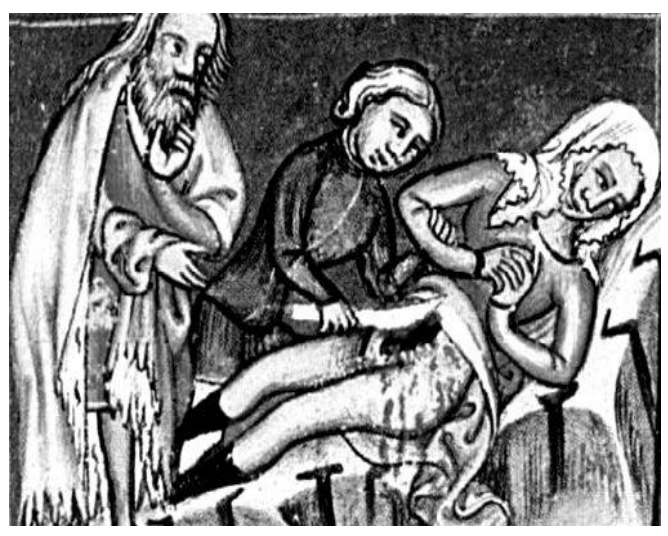

Figure 16. Nero and Agrippina -

Bayrische Handschrift, c 1410,

Heidelberg

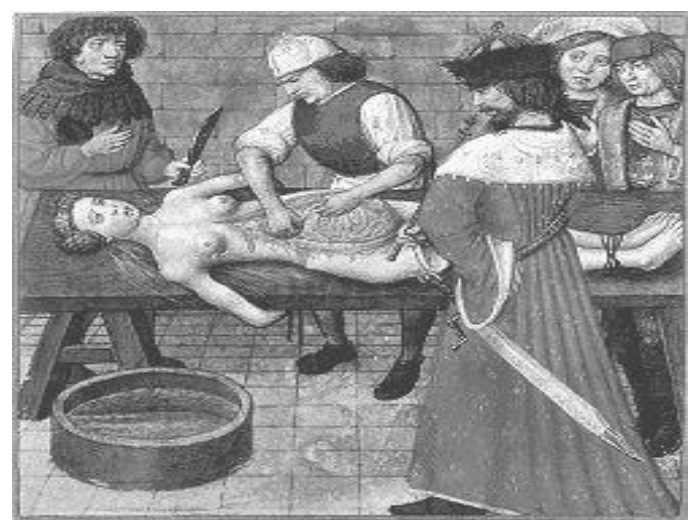

Figure 17. Nero and Agrippina - BrLib ms 4425, fol 59R, Flemish, ca, 1500

\section{Cruelty in Perfection}

Key in understanding Perfection are changes from woodcut to engraving; with those depicted identified by comparison with contemporary images (Figures. 18-25).

53. H. Fielding, The History of the Adventures of Joseph Andrews (London: Millar, 1742). 

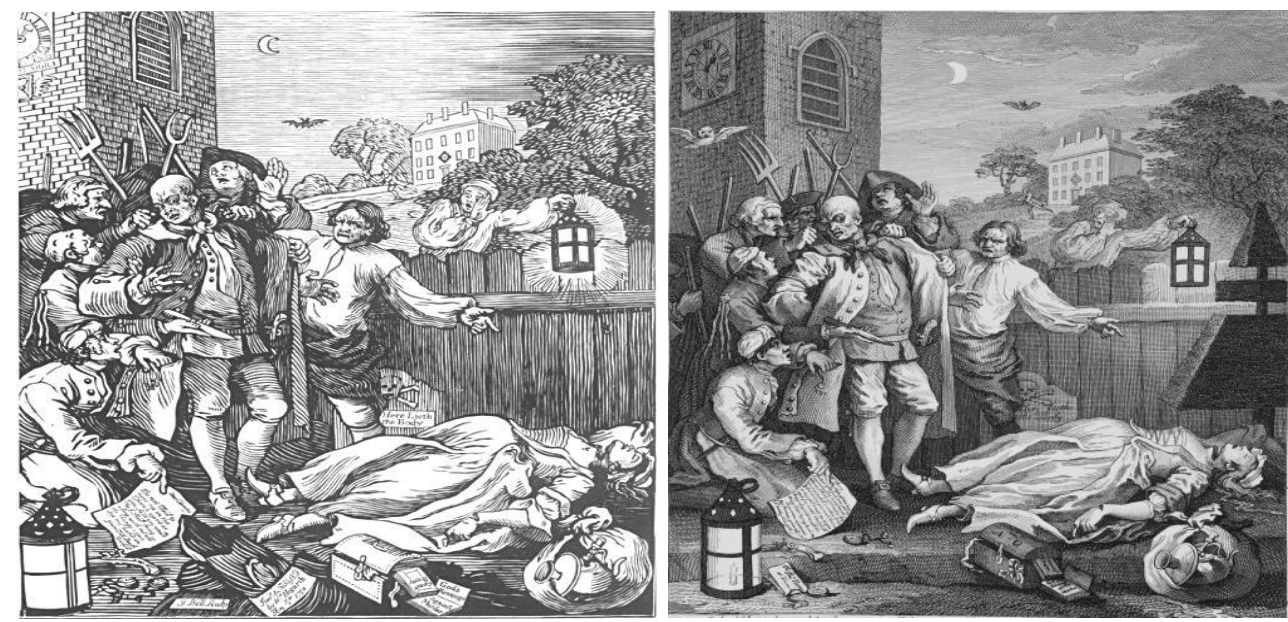

Figure 18. Cruelty in Perfection, Woodcut Figure 19. Cruelty in Perfection,

Engraving

Hogarth often included self-portraits, including in Perfection; Hogarth with his distinctive snub nose looks heavenward in both woodcut and engraving seeking "Gods Revenge Against Murder", as on a book in the foreground; John Reynolds's, Gods Revenge Against Murder, first published in 1621. Grignion's engraving of Smellie from a portrait by van Rymsdyk, reveals him as Tommy Nero; bald head, dark eyebrows, strong nose, and firm chin. A significant change from the woodcut is alteration of two heads on the left, those of John and William Hunter. In the engraving William's prominent nose and chin are reduced, and John changed from a smartly dressed young man to a servant; converting them both, and an extra head, into anonymous onlookers. The alteration reinforces the view William saw a proof of Perfection, was fearful at his inclusion, and begged Hogarth for changes.

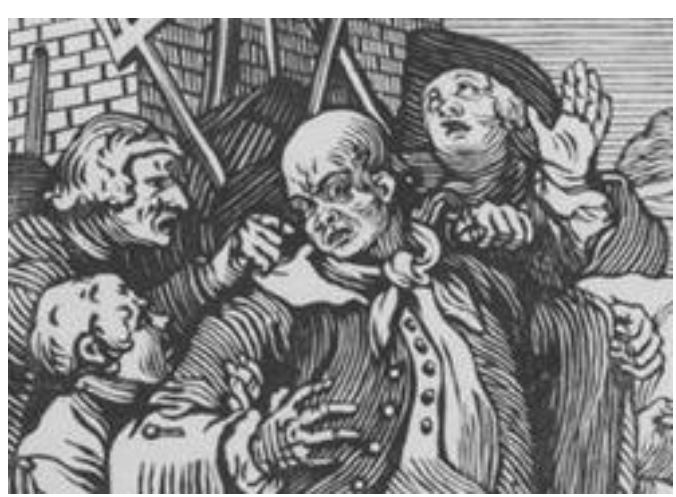

Figure 20. Cruelty in Perfection -

Woodcut

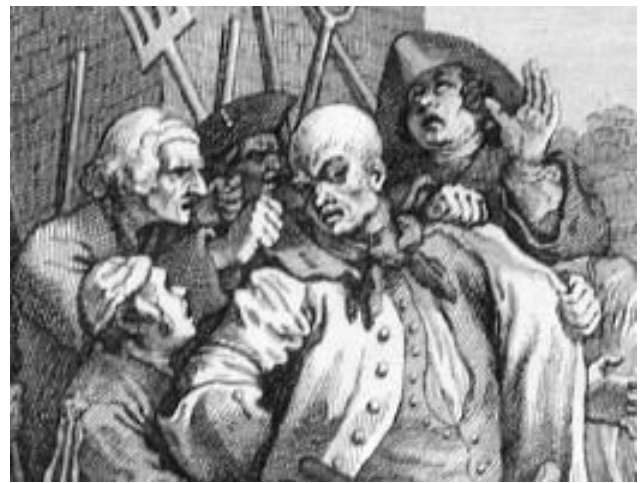

Figure 21. Cruelty in Perfection -

Engraving

In the woodcut the moon points to the "good" right, away from the church, but in the engraving it points at the "evil" church on the left; on the right a mitre shaped topiary yew shrub is added, as a need for "you" (yew) Church bishops to 
halt murders by anatomists. A puzzle with Perfection is why it appears to be in a churchyard? But does it? Hogarth includes vignettes to indicate the murder did not take place there. Both assistants, Mackenzie and Harvie, left and right of Smellie are wearing surgeons' aprons, not graveyard attire. To stress the awful truth hidden in Perfection, and alert a viewer the print reveals only half of his implied message, Hogarth adds an owl to the engraving. The owl was sacred to Athena, Goddess of Wisdom, with ability to light up Athena's blind side, to see the whole truth, instead of half the truth. The loss of a wig was used to portray a loss of one's reason; Smellie's lack of a wig, taken with the bat and bell tower, signifies Smellie is "mad" with "bats in his belfry". Hogarth puns the tombstone and fully clothed body are "lying" (telling untruths to hide the site of her naked murder), as the tombstone states: "Here lieth the body."

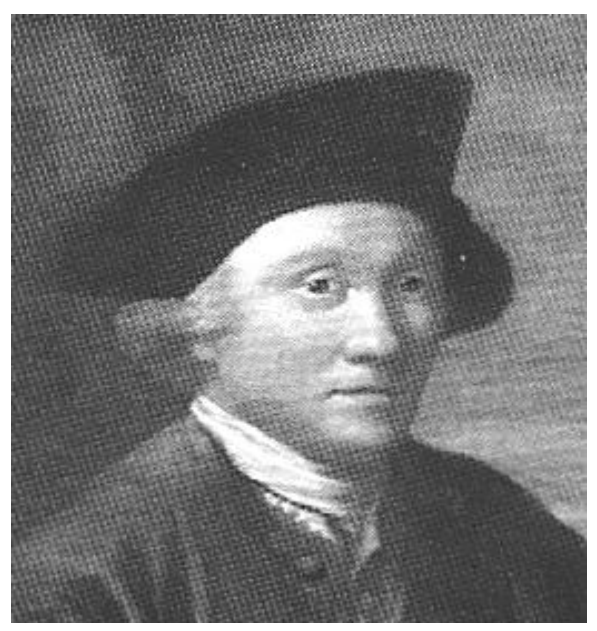

Figure 22. John Hunter

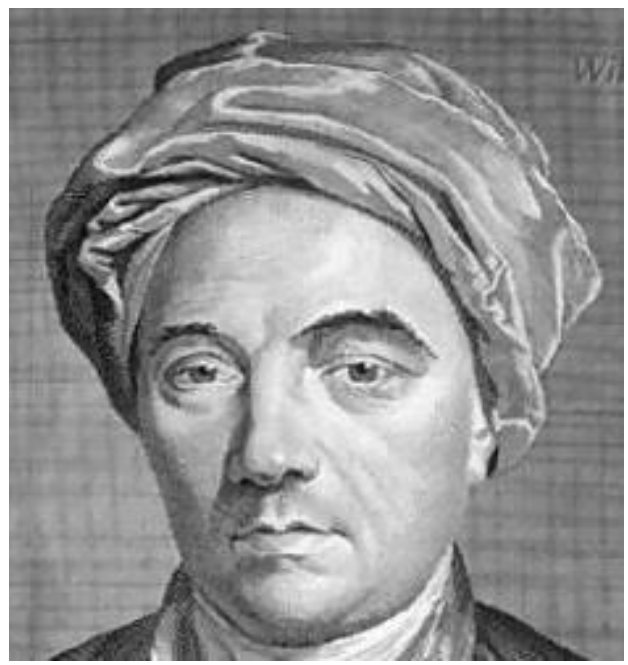

Figure 24. William Smellie

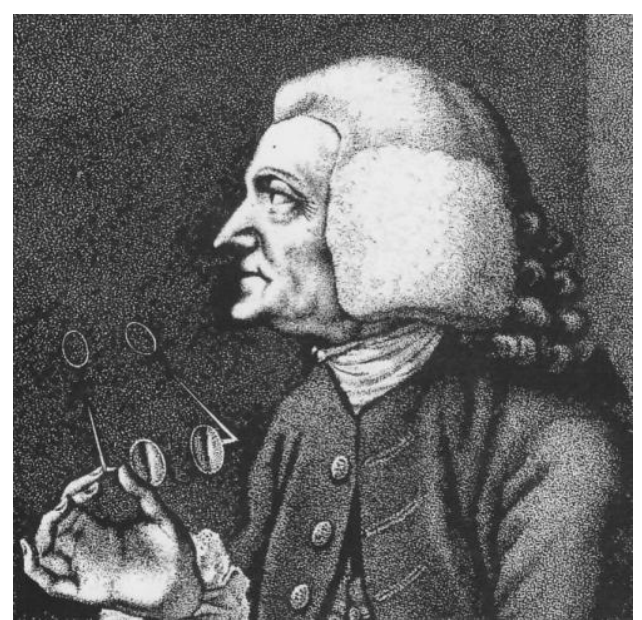

Figure 23. William Hunter

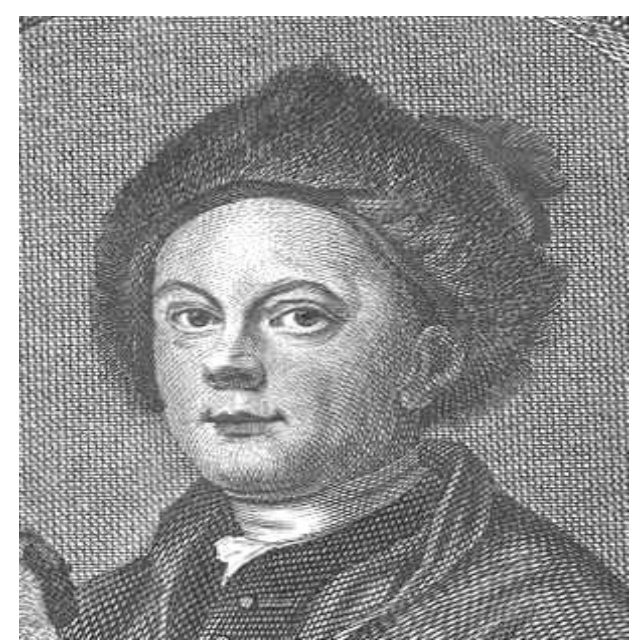

Figure 25. William Hogarth 
With these satiric puns read in conjunction with "loose ends" hanging from Ann's casket, Hogarth alerts the viewer Ann's death did not occur clothed in the churchyard, but instead as a nude pregnant victim murdered during an experiment. Analysis of Perfection in the context of man-midwifery, implies a relocation of the image to Smellie's rooms, mimicking Emperor Nero and Agrippina, and what Hogarth saw in Hunter's dissection room. A nervous Smellie is offered a surgeon's knife by John Hunter and urged to attempt a Caesarean on a pregnant and freshly murdered Ann; with her supine position that of a subject awaiting dissection. Her finger points at her Common Payer book, implying a prayer for Gods Revenge Against Murder, as in the title of her book. Other puns show the risks for Smellie of proceeding with a Caesarean; execution by "hanging" was punishment for robbery, as shown by the pistol, silver plate, and "time is ticking" watches; a spectator "drawing" near whispers to Smellie of the threat of punishment by "quartering"; evident in two lanterns and a "quartered" symbol visible over the house door. The bag of silver plate on the right hints a Biblical "thirty pieces of silver" as sufficient to betray Smellie.

Hogarth even reveals the method of murder before commencing a Caesarean. It was vital the fetus not be killed, so poison could not be used and, as it was believed the fetus breathed via the mother, smothering was avoided. Ann has a slit wrist and her throat is cut, with the absence of blood by her neck in the woodcut an indication of careful bleeding to death in the dissection room. Her finger then cut to check if the flow of blood had ceased. The image implies mothers restrained and gagged, their wrists slit to bleed to death as least risk to the fetus, and in the belief its blood circulation was independent of the mother, with the coup de grâce to the throat when the experiment was to commence. The lack of blood on the knife in the woodcut, nor on Ann's neck indicates bleeding to death. However, in the engraving there is blood on the knife and pooling on the ground by her neck, plus a rope around Smellie's arm, as a misleading refocus from obstetric experiment, to imply a churchyard arrest for robbery and murder. Nevertheless Hogarth ensures the accompanying verse has dual meaning; "By her Beguiler bleeds" conveys Ann as bled to death by Smellie.

The engraving adds "Thos. Nero" to the envelope, with the name Nero absent from the woodcuts of both Perfection and Reward. There is a pun on Ann's human "remains" and a subtle change alters the woodcut letter addressee from "Dear Tommy" to "Dr Tommy", a pun on Doctor Anatomy. There was a stage in the eighteenth century when "anatomy" was transmuted into "an atomy". Here Hogarth focuses on "an atomy", "a Tomy", then "Dr Tommy". Jeff Aronson discussed this change in the British Medical Journal:

[A]t one time the indefinite articles "a" and "an" were joined to the words that they governed, for example, aman or anoke. When the words were later split again, some spurious words were formed in error, for example, instead of a naranj we have an orange, and instead of a noumpere we have an 
umpire. This process is called metanalysis, one casualty of which was "anatomy". Anatomy is from the Greek "I cut up". In addition to its current meaning, the study of the structures of the body or the structures themselves, at one time it also meant a skeleton. When the indefinite article was being restored to its separate existence, the word "atomy" was falsely coined from "anatomy" through aphaeresis, by the removal of the supposed indefinite

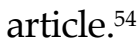

The letters depicted imply Ann's death at the hand of Smellie, while referring to Tommy: "Dear Tommy, Do not Fail to meet me in the Church yard as you said you would. For I shall bring along with me all the things I can Lay my hands upon yours Till Death Ann Gill." A later state of the woodcut has wording close to that of the engraving: "Dr Tommy My Mistress has been the best of Women to me, and my conscience flies in my face as often as I think of wronging her, yet I am resolv'd to venture Body \& Soul to do as you would have me so don't fail to meet me as you said you would. For I shall bring along with me all the things I can lay my hands on. So no more at present but I remain yours till Death. Ann Gill." The refocus on Ann's conscience in the second letter seeks to suggest she is guilty of theft, whereas the first letter implies an innocent Ann arriving as an indigent patient with all she owns in her casket, i.e. the unborn child in her belly. The word "Lay" in the letter being a pun on her needing "lying-in", i.e. for an imminent childbirth.

\section{The Reward of Cruelty}

After identification in Perfection, the key figures are readily seen in the Reward woodcut and engraving, Figures 26-27. After his late 1750 visit to see Hunter dissect a gravid uterus, Hogarth did not need to draw on other works in composing Reward, nor even the images of Emperor Nero. He posed Hunter as he had seen him, dissecting the gravid uterus of a murdered woman, John Hunter recording, and with van Rymsdyk preparing drawings. In a parody of a Caesarean, Hogarth depicts William Hunter, with his glasses, distinctive profile, and surgeon's apron, in the process of hanging, drawing, and quartering Smellie; a punishment reserved for heinous crimes, as Hogarth indicates hanging was inadequate. The rope around Smellie's neck and agony on his face reveal he was cut down from the gallows while alive, and brought to the table for "drawing", thence to be "quartered". His punishment by hanging, drawing and quartering, is hinted in puns through the satire. Smellie's left (a Latin pun, sinistra = left = evil) forefinger points at a "smelly" boiling pot. A dog eats Smellie's heart; Hogarth's view of Smellie as "heartless", but now deservedly "heart less".

54. J. Aronson, “When I use a Word”, BMJ (2000 Oct 14); 321:953. 
Van Rymsdyk made many anatomical "drawings" for Smellie and Hunter. For 250 years his appearance was unknown, but he sits in the right foreground of Reward "drawing" out Smellie's entrails. His description corresponds with one by Richard Smith: "The Ship was frequented by musicians, artists and interesting Bohemians, who led a jovial rollicking life. Among these characters were Rymsdyke, the painter, who dressed in "large flap waistcoat, immense cuffs to his coat sleeves, with breeches just to the knee, and slit before, with knee buttons". ${ }^{55}$ Van Rymsdyk had ample access to murdered subjects, and a pause for reflection brings the shocking realisation he required prior warning of each impending murder, to be present at Smellie's or Hunter's rooms, with art materials, and ready to draw. That presence is implied in his 1778, threat to expose William Hunter, in the guise of Dr Ibis: "O if I had a mind to speak how could I expose you, in what we commonly call a great length". ${ }^{66}$

Hogarth left the faces of the Hunter brothers unaltered in the engraving, convincing them they were on the side of meting out justice, whilst retaining his personal view the punishment they deserved was to dissect Smellie. Hogarth at left rear points to the fate of Smellie, with a message for Hunter. There are two niches for skeletons, with Hunter in due course required to occupy the right-hand niche. The unnamed skeletons in the woodcut point at each other, as anatomists blaming each other for their fate, as will Smellie and Hunter when they occupy the niches. For the engraving the skeletons are given names of prominent criminals to divert public attention from man-midwifery. On the left is James Field, tried before Henry Fielding and executed on 11 February 1751. Most changes between woodcut and engraving are minor, but significant is addition of the initials " $\mathrm{T} \mathrm{N}$ " to the biceps of Smellie, part of the camouflage to imply the man dissected was Tommy Nero, rather than Smellie. John Hunter, as a student learns "at the foot of the master", William Cheselden, author of Anatomy of the Human Body, is at Smellie's head, answering Ann's plea for revenge of "an eye for an eye". Cheselden was so shocked at appearing in Reward he gifted fifty guineas to the Foundling Hospital on 3 May 1751; thence retired to Bath, where he had a stroke and died in 1752 (Figures 26-27).

55. J. Thornton, Jan van Rymsdyk Medical Artist of the Eighteenth Century (Cambridge: Oleander, 1982), 6.

56. J. Van Rymsdyk, Museum Britannicum ... (London: Moore, 1778), 83. 


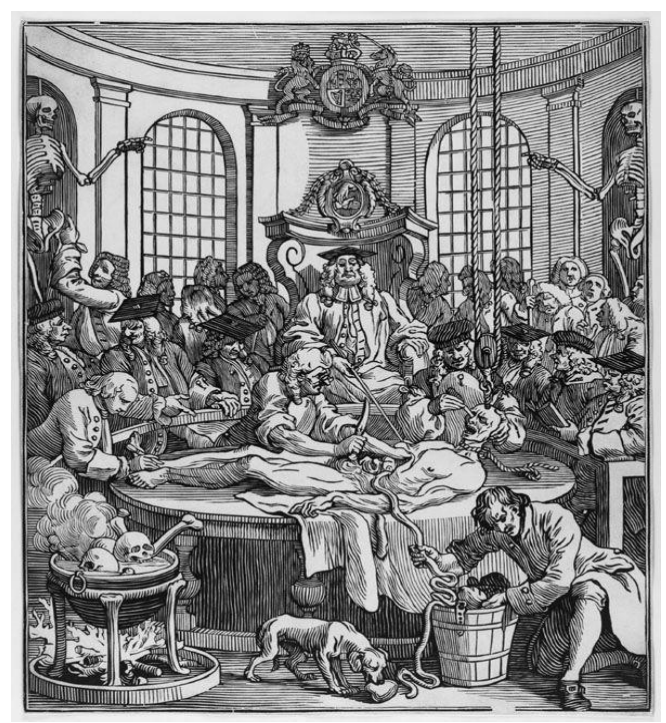

Figure 26. Reward of Cruelty - Woodcut

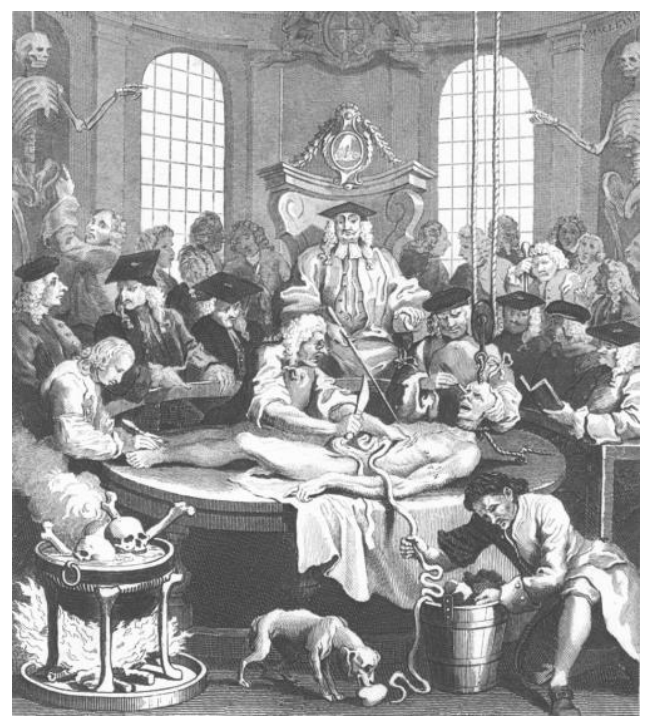

Figure 27. Reward of Cruelty Engraving

Some suggest John Freke presides, but it is more likely Sir Richard Manningham, who stated a Caesarean should be performed only after death of the mother. On the right of Reward are other man-midwives, likely Brudenell Exton, Percival Pott, and Benjamin Pugh. The hatted young man on the left is possibly Smollett, with the back-to-back critics as Frank Nicholls, with a prominent nose, and Robert Nesbitt. Nesbitt led a pro-Smellie/Hunter faction, and had a bitter altercation with Nicholls. The accompanying verses were reportedly composed by Rev. James Townley, but references to "tart" and later to "hoary", are unlikely for a Reverend; with "lawless Love" and "lawless Lust" referring to the sexual nature of crimes against women.

Reward emboldened Mary Cooper to publish the 1751 satirical pamphlet, $A$ Petition of the Unborn Babes. Previously attributed to Frank Nicholls, but new research suggests it is a Smollett satire; he often published polemic pamphlets with Cooper; with his identity hidden behind pseudonyms and spurious imprints. The Petition puns concern about; "the polite and tender Behaviour of Pocus [Smellie], or the delicate Wit and lively Imagination of Maulus [Hunter]".

[W]e your Petitioners have of late Years been grievously ill-treated by Dr. Pocus, Dr. Maulus, and other evil-minded Men ... we your Petitioners particularly charge, that if we cannot leave our Dwellings, and make our Appearance, so soon as is expected, either from the Unwieldyness of our Gates, or by means of any other Obstacle ... we are forthwith drag'd out of our Habitations by Hooks, Pincers, and other bloody Instruments, whereby we are sometimes most miserably torn and bruised, and at other times our Heads are so squeezed, that we are ever after subject to Fits ... And in the case of any the least Resistance, whether on our part, or from the Nature, and 
Situation, of our Habitations, we are sentenced to Death as guilty of Rebellion, and in consequence of such Sentence we are sometimes beheaded, and at other times our Brains are torn out by Instruments wickedly contrived for that Purpose ... Or if your Petitioners happen to put an Arm out of Doors, whether in our own Defence, or to feel our way, the said Pocus, Maulus, and their Confederates, immediately cut off such Arm as high as they can reach; by which means your Petitioners bleed to Death in great Misery and Torture. ${ }^{57}$

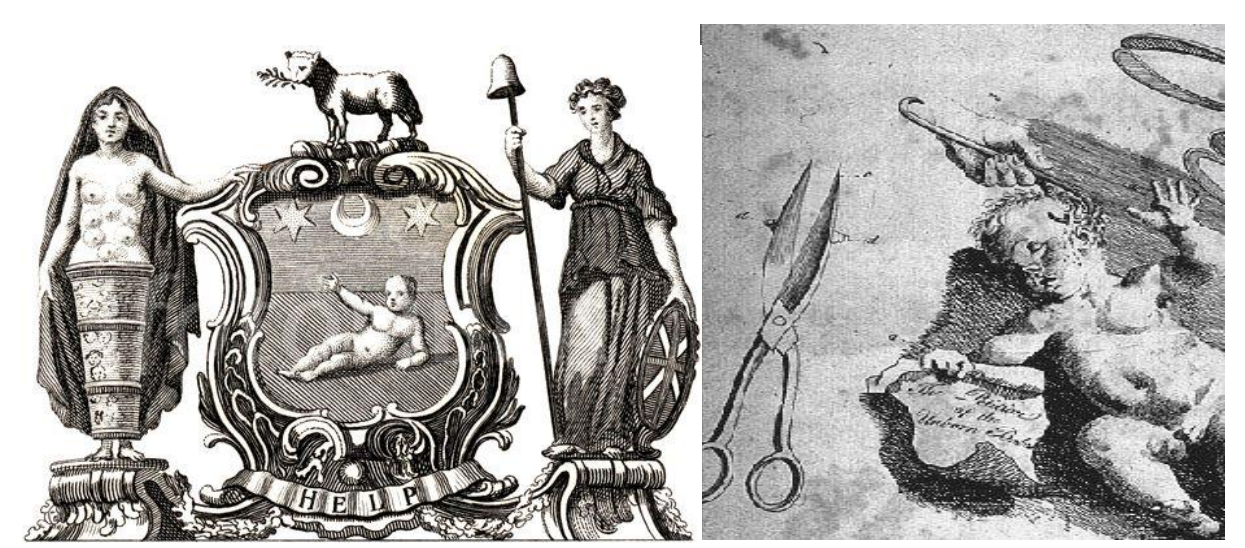

Figure 28. Foundling Hospital Arms 1749 Figure 29. The Petition - Fetus

killed by instruments - Wellcome

The Petition ironically attributes Dr Pocus as stating unborn children were not entitled to protection from Church or State, "neither being [baptised] Christians, nor having taken the Oath". It includes a copper plate, with the reverse of an infant's pose, similar to a coat-of-arms adopted for the Foundling Hospital (figures 28-29).

\section{The First Stage of Cruelty and The Second Stage of Cruelty}

After an initial rebuff by Hunter in December 1750, Hogarth's anger led him to prepare woodcut proofs to confront Hunter. Hogarth was not in a strong position, with the subjects dissected and gone he was unable to table evidence after Hunter refused to cease. As a sign he was serious, Hogarth told Hunter he would publish engraved plates of Perfection and Reward, Figures 30-31. Hunter realised he faced risk of trial and execution if Perfection and Reward were published. Hunter saw an undertaking to halt obstetric research as a chance to persuade the authorities to raise the legal allocation of executed criminals for dissection, beyond the minimal annual allowance of ten bodies. Hunter agreed to cease experiments, provided Hogarth refocused Perfection and Reward away from

57. Anon, The Petition of the Unborn Babes... (London: Cooper, 1751), 4-7. 
man-midwifery. Hogarth did this by expanding the series from two to four; in creating two preceding engravings, with a veneer of animal cruelty and Tommy Nero as villain. Titled The First Stage of Cruelty and The Second Stage of Cruelty; allowing Perfection as a notional third stage, and Reward as a fourth stage; with the revised set completed a week after issuing Beer Street and Gin Lane.

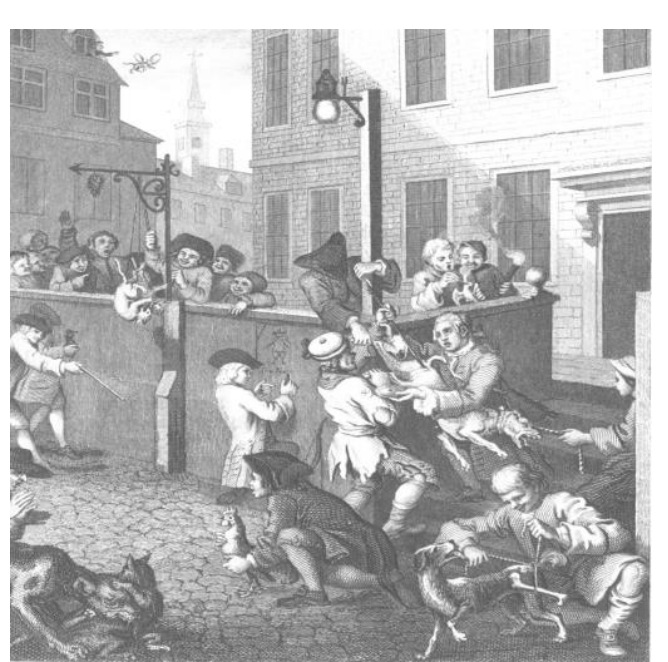

Figure 30. First Stage of Cruelty

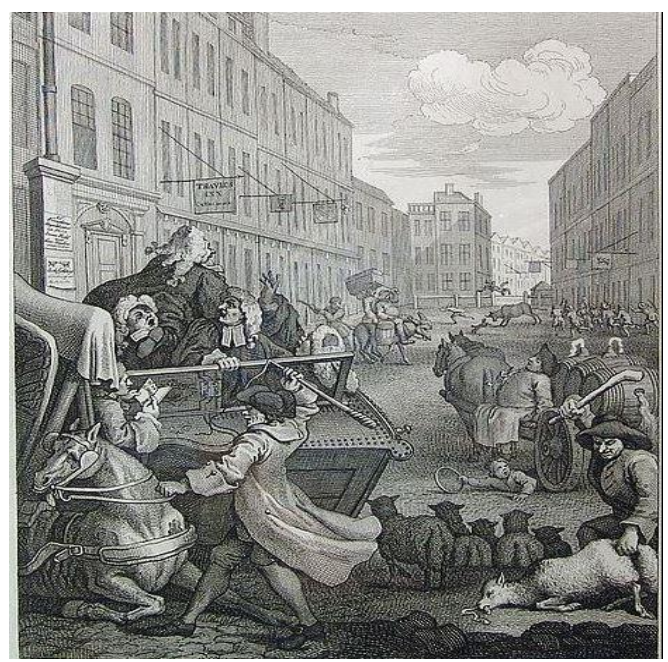

Figure 31. The Second Stage of Cruelty

In the First Stage the actions of young Smellie and Hunter indicate how The Petition derived the names Dr Maulus and Dr Pocus. They "fight like cats", "mauling" the dog and intent on being first to "poke" an arrow into the dog's vagina. John Hunter joins in, grasping Smellie's wrist, and saying in the accompanying verse, "take all my Tart"; as he offers a pregnant prostitute as substitute in their "fetus hunt". The letters on Smellie's sleeve can be read as "S G" for the parish of St Giles, but Hogarth punned them as "S C" for the Surgeons' Company, formed in 1745, and to which man-midwives belonged. Adding Nero to a wall helps redirect attention at Tommy Nero. The snub nose of the boy "drawing" a hangman picture shows it as a self-portrait of young Hogarth, foretelling the fate of Smellie and Hunter. In the right foreground of the First Stage young van Rymsdyk squats in the same pose as in Reward. As implied by boys blinding a bird, Smellie and Hunter face an "eye for an eye". Vignettes of a rope around one dog's neck allude to "hanging", a second dog will soon be "drawing" a bone, and the defeated cat in the left foreground begs for "quarter" from a third dog. The image of a cat [prostitute] and balloons thrown from a window is a pun on the saying "pigs might fly"; but prostitutes can't fly away, and thus will die. Hogarth alerts viewers to a hidden message in another vignette by the wine motif represented as "the grapes of wrath". The grapes refer to a Biblical quotation from Revelation 14:19, an apocalyptic appeal for divine justice: "And the angel thrust in his sickle into the earth, and gathered the vine of the earth, and cast it into the great wine-press of the wrath of God". The grapes also bring attention to 
the acts of sin in Ezekiel 18: "The fathers have eaten sour grapes, and the children's teeth are set on edge"; salvation does not depend upon hereditary conditions, but upon present personal character, fixed in actual life. The "hanging" of two "fighting cats", adjacent to the "hanging" bunch of grapes shows the two men "fighting like cats" will face divine justice for their murders.

The Second Stage contains more vignettes referring to murder, prostitution, and man-midwifery, Figures 32-35. The weeping horse and verse, "The generous Steed in hoary Age, Subdu'd by Labour lies", represents Smellie flogging a helpless "whore", as she cries in painful "Labour", i.e. childbirth. On the right, Hunter kills a "lamb", representing children murdered while innocent as lambs. John Hunter takes study notes with the number "24" referring to Smellie's murders of pregnant women, wherein he took "two for" one murder. The poking with a pitchfork of an overladen and immobile donkey, alludes to manmidwifery impatience and excessive use of obstetric instruments in hurrying fullterm and helpless parturient women, struggling in labour. Again there are allusions to Smellie's fate; the juxtaposition of the door frame and whip handle mimic the several "hanging" signs as images of gallows, and the thong of the whip by his neck implies the "hanging" rope. The risk of harming of children by "drawing" is shown in a boy trapped under the dray, "drawn" along by an oblivious driver, with bull baiting and chasing of a bull resembling "quartering", wherein a pack of dogs chased its quarry. The driver of the dray sleeps on his way home after a night collecting "night-soil", with the contents and "smelly" fumes of the barrels expressing Hogarth's contempt for Smellie and his works. The night-soil collector in Figure 32 mimics a similar figure in Hogarth's 1738 Night.

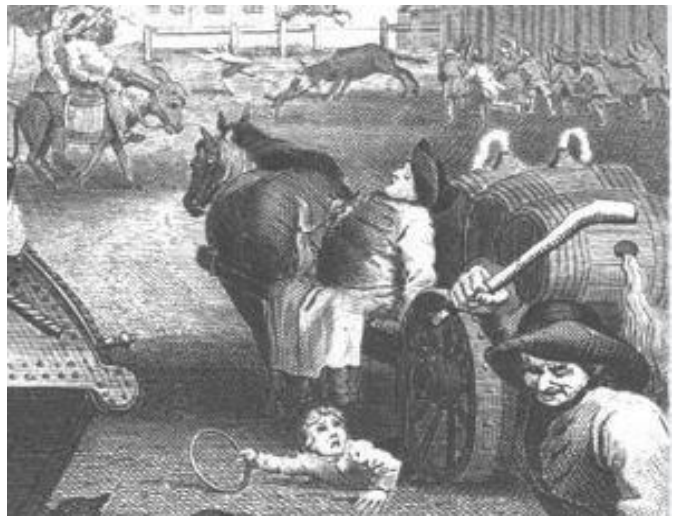

Figure 32. Night Soil Collector

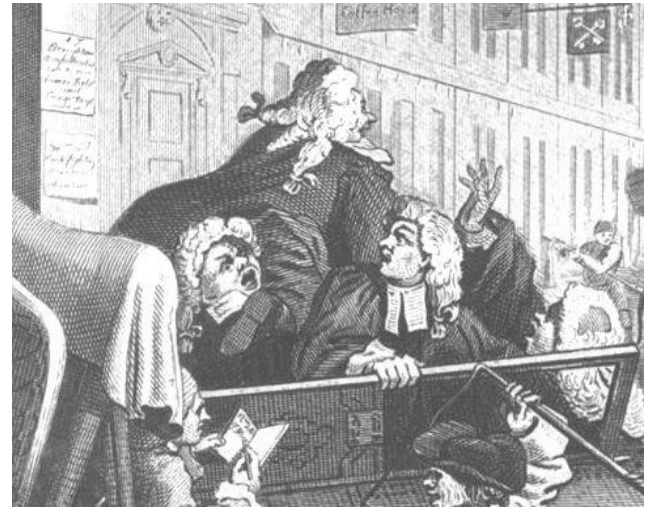

Figure 33. John Fielding and Henry Fielding

The lawyers pun the law's wilful blindness to murders committed by anatomists, with a hanging sign for "Thavies" as a pun on the "hanging" of "thieves". The lawyers are magistrate Henry Fielding and his blind brother, John; note Henry's nose and firm jaw, and John's "baby brother" appearance, Figures 
33-35. Fielding grasps the door frame representing gallows, whilst gazing at a poster advertising a fight by James Field; tried and convicted for robbery before Fielding on 16 January 1751, and hanged on 11 February. The poster was added to a preliminary drawing depicting Fielding gazing at a doorway, with dates important in analysing Four Stages of Cruelty.

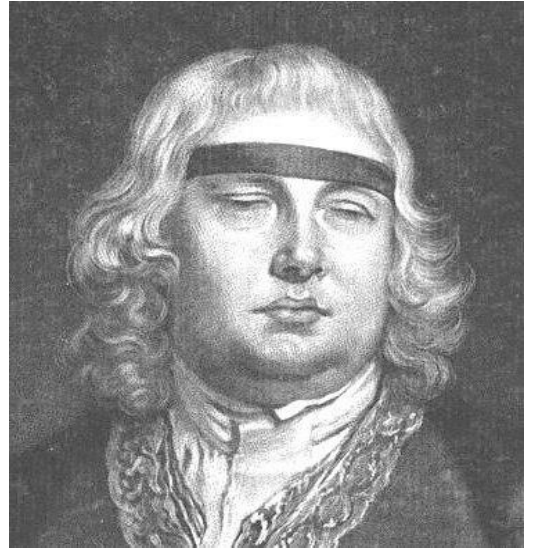

Figure 34. Blind John Fielding

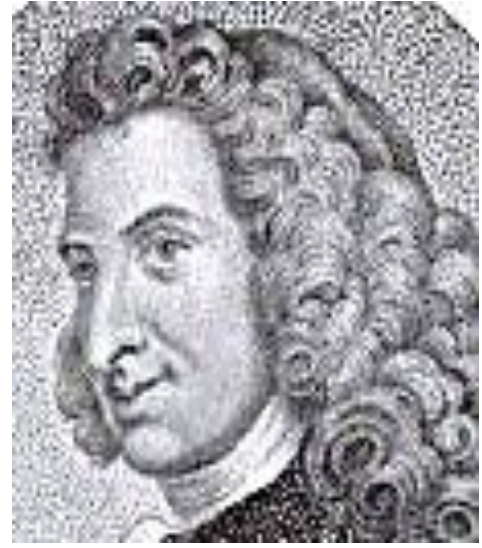

Figure 35. Henry Fielding

Being after the 1 January 1750 date on Bell's woodcut, they support the original design as the woodcut images of Perfection and Reward but, published in a set of engravings, were preceded by First Stage and Second Stage. That late refocus on animal cruelty, is why the prints lack the passion and intensity of Perfection and Reward. On publication those depicted in Perfection and Reward recognised their images. Risk of trial and execution, if not hunting down and slaughter by a vengeful public, was incentive for secrecy among man-midwives, even if innocent of crimes.

\section{Hogarth's Original Intent for Beer Street, Gin Lane, Cruelty in Perfection, and Reward of Cruelty}

Hogarth's cryptic Satire in Four Stages of Cruelty used irony and exaggeration to challenge cruelty to women: that contrasts with his Sermon on animal cruelty. In Beer Street and Gin Lane Hogarth challenged gin-drinking in a Sermon for the uneducated:

Choice is clear and unambiguous in Beer Street and Gin Lane, Hogarth draws on a tradition going back at least as far as Defoe's Augusta Triumphans (1728), in which beer opposes gin, as good against evil and, of course, industry to 
idleness. There is almost no ambiguity here about the contrast between order and chaos. 58

Beer Street, however responsible for the evils of Gin Lane, is nevertheless (Hogarth is saying) all that English artists and writers have to work with, and the future lies in national fisheries and projects that link art and commerce, which indeed he will himself explore in the succeeding years, and not in an attempt to recover classical art and its manner. ${ }^{59}$

Paulson's "clear and unambiguous" opinion of Beer Street echoes Steintrager's "almost banal" view of the First Stage of Cruelty. There is no reason to doubt the Sermon, but what about Satire? Are Hogarth's Beer Street and Gin Lane two more examples of satire overlooked for 250 years? Announcement of Beer Street and Gin Lane in the same 1751 advertisement as Four Stages of Cruelty, hints at Sermon and Satire in all six prints. They are of similar dimension, style, verse, and London location; raising caution against a claim Hogarth's satire was limited to four of the six engravings. The challenge is to reveal previously unnoticed satire in Beer Street and Gin Lane; which, linked to Perfection and Reward, implies a four part-satire was Hogarth's basic intent. A cue is that Fielding wrote of Beer Street: "The ingenious Hogarth hath very finely satyriz'd this, by representing several of the most valuable Productions of these Times on the Way to the Trunkmaker".

Fielding's words signal his belief in Beer Street and Gin Lane as ingenious satire. Analysis has uncovered the satire, with numerous Hogarth puns emerging in Beer Street and Gin Lane. Hogarth used exaggeration as a satirical device, but in Beer Street a technique is irony: "the humorous or mildly sarcastic use of words to imply the opposite of what they normally mean," a notional reversal of each vignette. In the preliminary drawing, the man resting while reading a paper has a blacksmith's hammer and grip; tools used to forge "iron" in a "smithy", hence to make "irony". A cobbler has a pile of old shoes, a warning the scene is a "load of old cobblers", or "a load of old nonsense". A paviour lays "cobble-stones", a hint the image is "cobbled together", as "something assembled roughly". A paper is titled Farthing Post, with two men pointing and laughing; a warning the scene is nonsense and "not worth a brass farthing", "nor the paper it is printed on". Two fish sellers suggest the scene is "fishy"; i.e. "suspicious, doubtful, or questionable". The sellers read a proclamation, but that would not be, as sellers were illiterate. In the published engraving, the proclamation advertises A New Ballard on the Herring Fishery; alerting the vignette as a "red herring", or "something diverting attention from a topic or line of inquiry". A basket of books is addressed to a "trunkmaker": Modern Tragedys Vo:12, Politicks Vol:9999 (both nonsense titles), plus Hill on Royal Societies, Turnbul on Ant[ient] Painting, and Lauder on Milton. They allude

58. R. Paulson, Hogarth, His Life, Art, and Times, vol. 2 (New Haven: Yale, 1971), 269.

59. R. Paulson, Hogarth Art and Politics, 1750-1764 (New Bruswick, Rutgers, 1993), 34. 
to authors whose views were challenged by critics or, as with Lauder, his claim about Milton was fraudulent. Thus, in viewing Beer Street; "one should not judge a book by its cover".

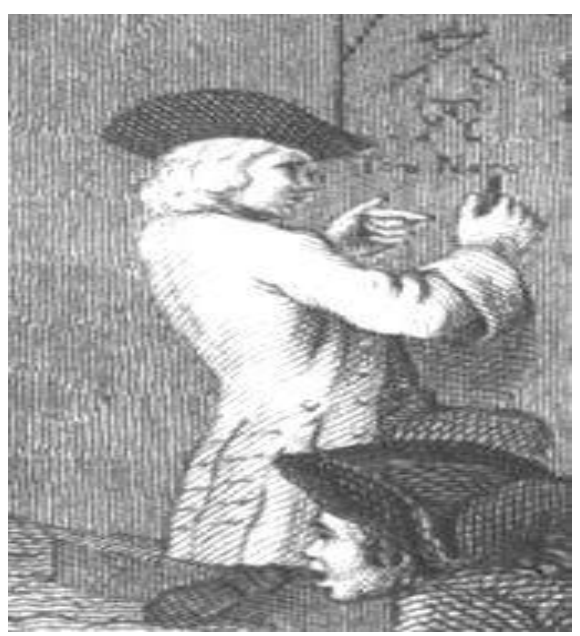

Figure 36. Hogarth self-portrait ex First Stage

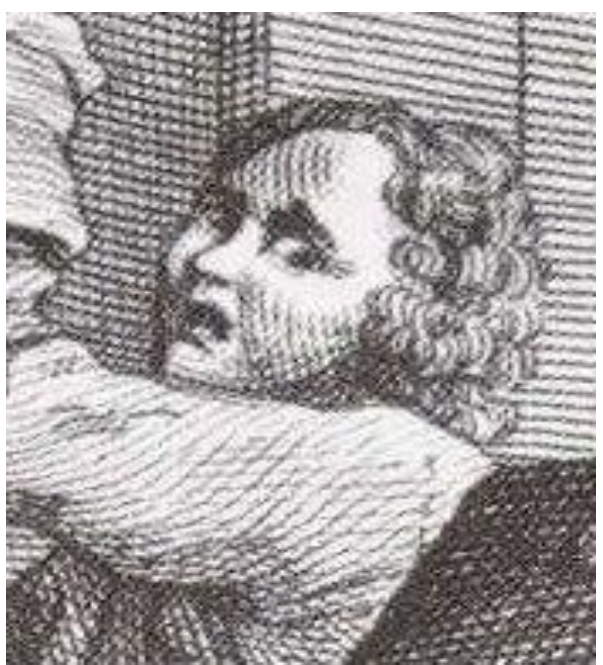

Figure 38. Hogarth self-portrait ex Reward of Cruelty

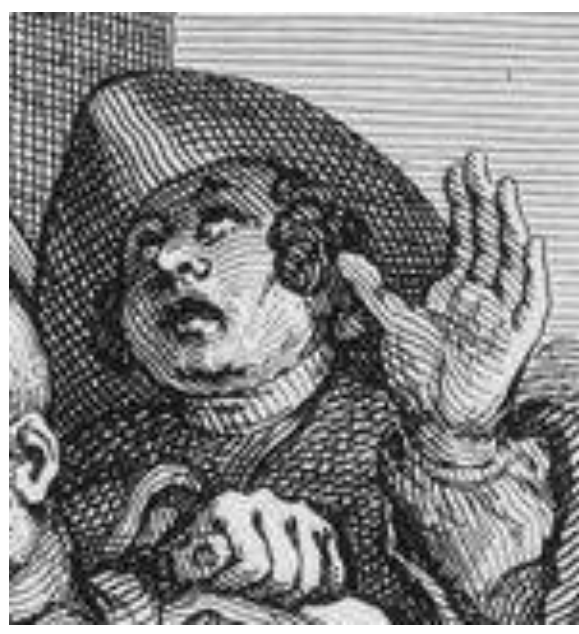

Figure 37. Hogarth self-portrait ex Perfection

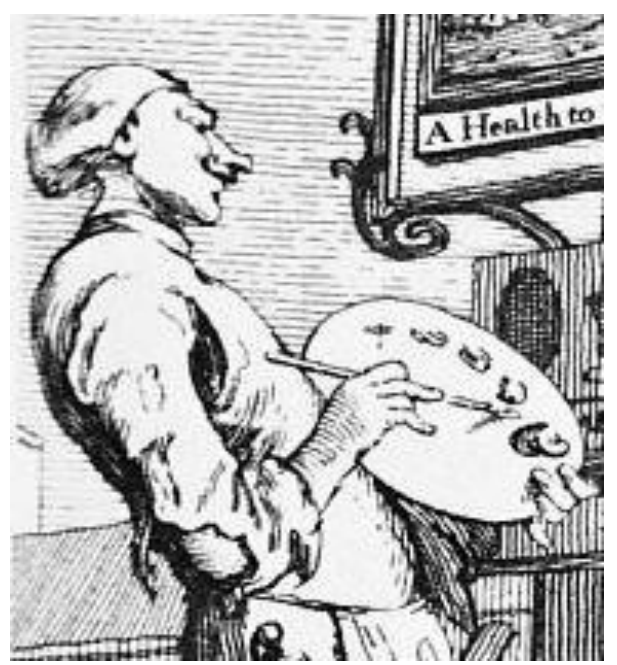

Figure 39. Hogarth self-portrait ex Beer Street

Hogarth's irony is key to interpreting Beer Street. Three snub-nosed selfportraits of Hogarth appear in; the First Stage; Perfection, and Reward; and a fourth self-portrait is in Beer Street; the snub-nosed sign-painter standing atop a ladder, "approving of", but remote from the activities below, Figures 36-39. In Beer Street a normal self-portrait would be expected to depict Hogarth's actual corpulence. But a literary convention behind irony prompts an opposing interpretation, requiring Hogarth's corpulence convert to thin. Hogarth's educated peers were alerted to his irony in a thin self-portrait, as a hint his approving visage should 
alter to disapproving. He thus still portrays his snub nose, but sylph-like and ragged, to imply he is saying: "Don't take my appearance seriously. Although appearing ragged, and sylph-like, I am a successful artist. My self-deprecating appearance is a cue for you to seek out other things which are not as they seem."

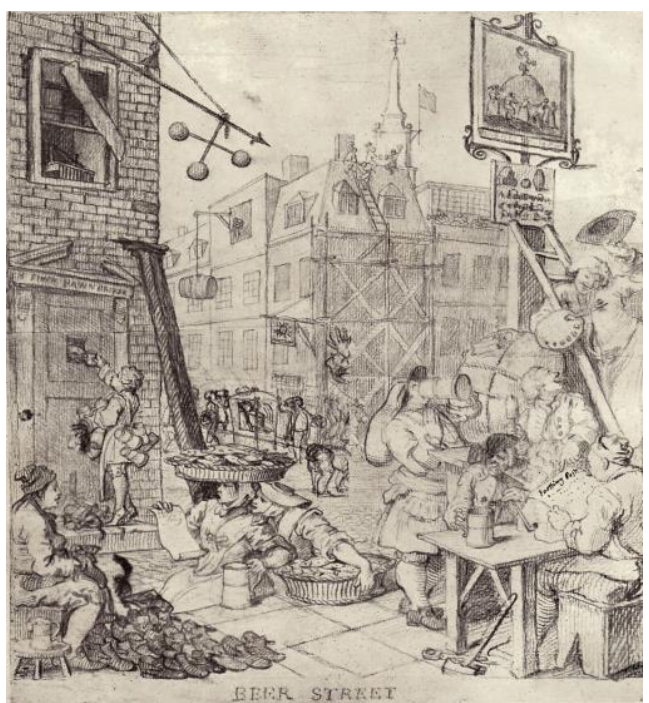

Figure 40. Beer Street - Preliminary

Oppê: 73 (76)

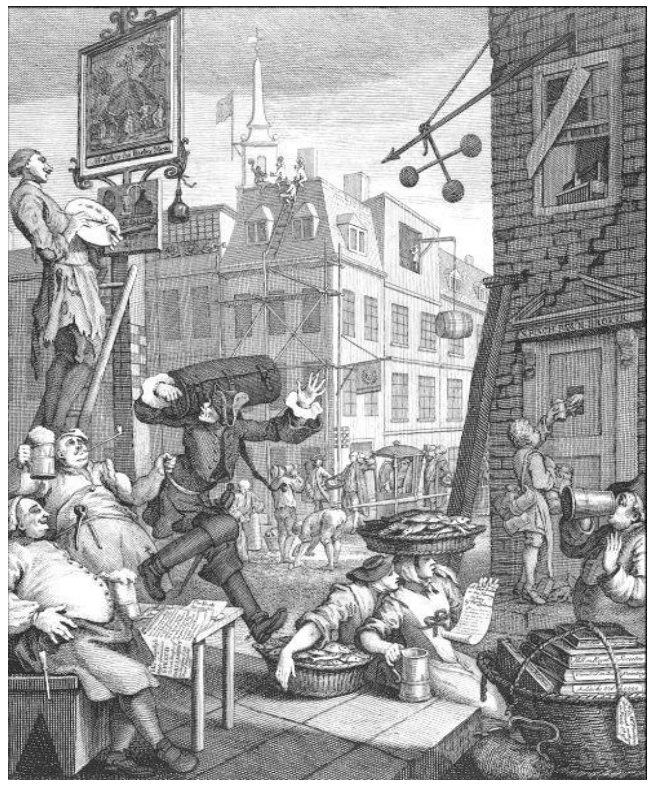

Figure 42. Beer Street - Second StatePaulson 197 (185)

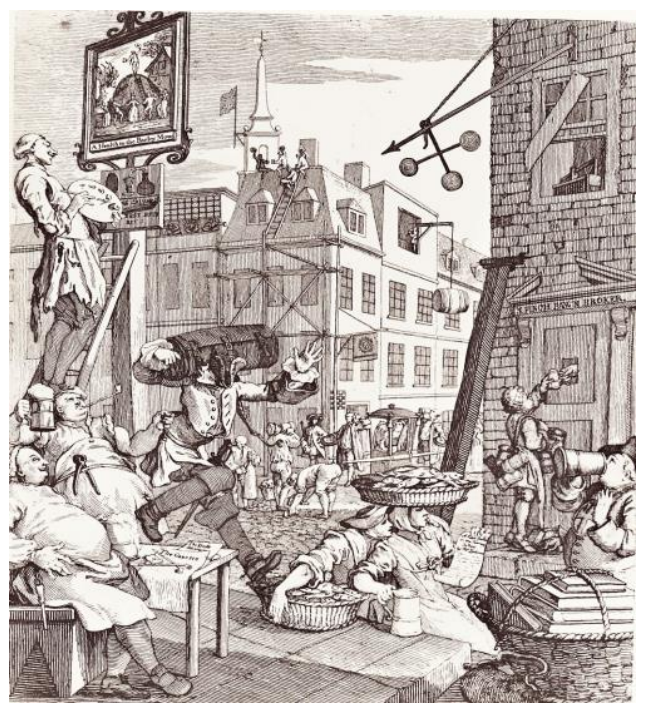

Figure 41. Beer Street - First State Paulson 252 (197)

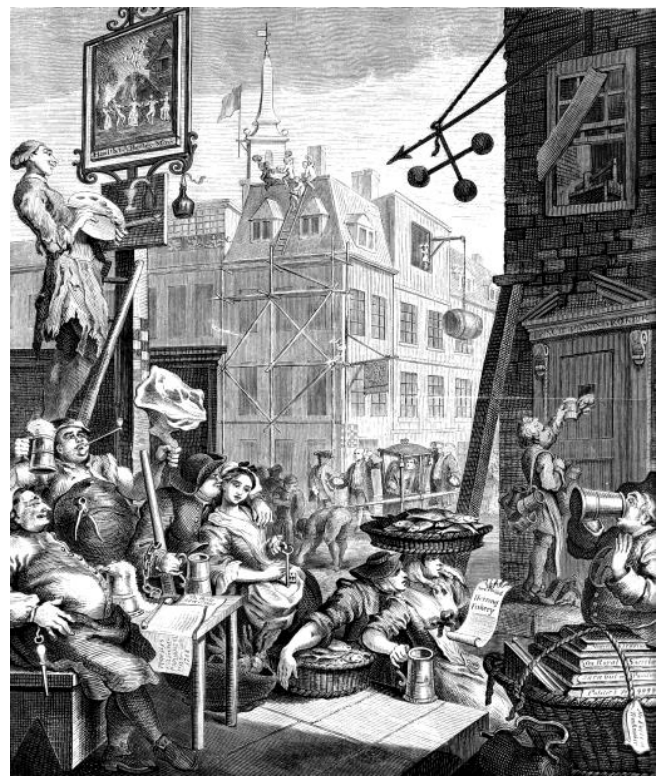

Figure 43. Beer Street - Third State Paulson 198 (185)

In seeking Hogarth's trail in Figures 40-43, it is relevant that, a month prior to Beer Street, Fielding published his Enquiry which, inter alia, condemned debauchery: 
And though Ranelagh and Vauxhall, by reason of their price, are not entirely appropriated to the people of fashion, yet they are seldom frequented by any below the middle rank. ... Nor should such a fashion be allowed to spread into every village round London, and by degrees all over the kingdom; by which means not only idleness, but all kinds of immorality, will be encouraged. ... the case is very different with these inferior masquerades, for these are indeed no other than the temples of drunkenness, lewdness, and all kind of debauchery". ${ }^{60}$

Although counter to conventional wisdom, Beer Street puns reveals Hogarth commenced with a vision of "drunkenness, lewdness, and all kinds of debauchery" at an "inferior masquerade". He then applies irony to individual vignettes, to derive ironic Beer Street images which reinforce Fielding's Enquiry. For example, the Barley Mow sign depicts happy dancing peasants, but irony converts their behaviour into "drunkenness, lewdness, and all kinds of debauchery". Hogarth satirises the King's speech, referring to "Advancement of Our Commence and cultivating the Art of Peace"; ironic allusion to a lack of peaceful thoroughfare, and crimes of robbery and violence, as enumerated in the Enquiry. Irony converts the rear "sun" inn-sign to "moon" to convey night, with an ironic peeling away of the chequerboard "licensing" motifs, revealing Hogarth's Satire as his vision of a debauched and unlicensed night-time masquerade. The irony continues as more vignettes are unlocked.

The "front door" key to the First Stage was an "arrow", whereas central to Beer Street a young lady holds a large key, Hogarth hinting "Here is the Key!" The Barley Mow sign alludes to courtship, as in a poem by John Gay: "Whenever by yon barley mow I pass, Before my eyes will trip the tidy lass". ${ }^{61}$ The courting of Ann Gill is identified via an adjacent vignette where trays of fish have "gills", as does "Ann Gill" and imply her as Hogarth's "angle". Irony demonstrates not courtship, but seduction. Ann is courted by a man often described as a paviour, but pounding mauls as used by paviours lacked chains and shackles. He is instead a dancing-bear owner, with "more tricks than a dancing bear". ${ }^{62} \mathrm{He}$ has a pole, chain, and shackle for the bear and seeks the "key" to Ann's affection, to take her "captive". If she succumbs to him, she risks descent into prostitution and pregnancy, as represented by multiple phallic imagery (erect carrots and onions) in her basket; with the poised leg of meat above her head, as her Sword of Damocles, anticipating her ultimate dissection as "a leg of meat".

60. H. Fielding, An Enquiry Into the Causes of the Late Increase of Robbers, Ec. (London: A. Millar, 1751), 9, 19.

61. J. Gay, Poems on Several Occasions, vol. 1 (London: H. Lintot, 1745), 110.

62. J. Swift, "Polite Conversation", Miscellanies, 4th ed., vol. 9 (London: Davis, 1748), 179. 
Ann's fate is reinforced via reference to Irene a play by Samuel Johnson, a contemporary of Hogarth, who draws attention to Johnson and hence Irene, by hints at his appearance. Johnson, noted for profanity and bawdiness, was strong and bear-like. As noted by David Nokes; "he would 'feed him occasionally with guineas', making the distasteful but understandable comparison of Johnson with a chained-up bear". ${ }^{63}$ The man courting Ann is thus Johnson, via a vignette linking to Irene. Johnson's Irene was performed in 1749, the central conflict being whether Irene, a Greek slave girl, will remain faithful to her religion, or succumb to Mahomet, a despotic sultan, to become his queen and lose hope of a Christian heaven. Johnson emphasises how the pursuit of worldly power tends to corrupt. In the play Irene does succumb, but becomes the victim of slander, and Mahomet has her murdered. Irene anticipates Ann's fate, with a hint in words below the Barley Mow sign. For the Sermon Paulson reads this as, “...AN CALVAR[t's] BEST BUTT [Be]ER", hence An[n] Calvart's Best Butt Beer. But in his Satire Hogarth puns on Biblical Calvary to show Ann's fate, “...AN CALVAR[y] BEST BUTT[ch]ER", thus "An[n], Calvary, best butcher."

A "leg of meat" as Ann's fate implies anatomists within Beer Street. In Reward and Paul Before Felix images representing "smell" or smelly" allude to Smellie. In Beer Street, "smelly" sellers carry "smelly" fish also alluding to Smellie. The First Stage implies Hunter "hunting" prostitutes; on the right of Beer Street is the home of a pawn-broker with, in an upper window, a trap for "hunting". A further allusion to Hunter is a pun on "pawn-broker", as "porne-broker", the word "porne" being Greek for prostitute. Hogarth's scholarly friends were familiar with Greek, with porne-broker" implying Hunter "buying" pregnant prostitutes; and irony converting Hunter's wealth and success to Beer Street's run-down house.

A French anatomist is in states one and two of the Beer Street engraving, but is replaced by Johnson, Ann, and a leg of meat for the third state. The anatomist is so "small" he is picked up by one hand, even though carrying a "trunk". The French for "small" is "petit" and quoted earlier were comments by Jean Louis Petit, Director of the French Royal Academy: "In order to be sure of our procedure, we must have dissected women who have died both before and after delivery". ${ }^{64}$ Petit's "spurs", sword ("large knife"), and "trunk" signal him as a "horseman" in the Sermon, but for the Satire as a "whoresman" an anatomist dissecting "whores" to make "trunks". Hogarth became attuned to Petit's research when observing Hunter's dissection of a gravid uterus. Petit has a long queue (pig-tail) of hair, and implying a long "tale" behind his presence. Petit's "spurs" confirm him as a "spur" to obstetric experiments conducted by Smellie

63. D. Nokes, Samuel Johnson - A Life (New York: Henry Holt, 2010), 174.

64. J. Petit, "Remarks on various faulty conformations of the Anus in new born Children", ed. M de la Peyronie, Memoires of the Royal Academy of Surgery. vol. 1. (London: Cave, 1750), 247. 
and Hunter. Hogarth reinforces a focus as man-midwifery, via two men on the left with tools of trade. One has a butcher's steel for sharpening knives, also used by surgeons and anatomists, often described as "butchers". The other has pincers, "a gripping tool consisting of two hinged arms with handles at one end" as used by cobblers, or farriers to "extract" nails. This is a pun on "forceps - a surgical instrument in the form of a pair of pincers", as used by man-midwives to "extract" babies. "Pincers" as "forceps" is also an obstetric pun on the Beer Street and Gin Lane pawn-brokers, "N Pinch" and "S Gripe", as "pinch'n'grip".

Interpretation of Hogarth's Satire is akin to a dance of the seven veils, with removal of each veil revealing a Satire diametrically opposed to the Sermon. Prominent in Beer Street are men "raising", "supping", and "draining" "foaming" tankards; alluding to filling a prostitute with a fetus, then emptying her via dissection. Men in Beer Street "raise" tankards in a "toast" in anticipation of Ann's imminent "de-flowering". The multiple phallic imagery in her basket showing they expect to participate in her spiral into prostitution. A man on the right with a cross on his chest and relishing a tankard, extends Hogarth's anger to clergy guilty of neglecting to constrain anatomists and seeking out prostitutes. That refocuses on the fish sellers, implied to have a "fishy smell". In the eighteenth century a vaginal "fishy" odour was often associated with prostitutes, as their bodies rarely had time to readjust to a normal bacterial balance between clients. The sellers are thus prostitutes, one clutching an "empty" tankard. This is reinforced by "full tankards" offered in exchange for "empties" through the door of the "pawn-broker", implicitly the location of Hunter's dissection room, "behind closed doors", and a dead baby on his doorstep. The vignette implies John Hunter sourcing pregnant prostitutes for his brother, thus paralleling the pregnant "all my tart" he offers in the First Stage. John collects multiple empty tankards, representing the bodies of prostitutes, "emptied" of fetuses by Smellie and Hunter; with their human remains then fed to wild animals in a London menagerie.

Hogarth's disapproval is focussed as a warning to those Londoners involved in licentious behaviour, especially those exploiting prostitutes. Hogarth views their deserved punishment as "hanging", "drawing", and "quartering"; signified by roofers celebrating "topping-off" (completion) of a roof, with "topping-off" also referring to "the hangman's drop". Execution by "hanging" is further implied by a "hanging" barrel, with scaffolding as "gallows", diagonal bracing to imply "quartering", and a woman "drawn" along in a sedan chair. Stripping away the irony reveals her not as old and fat, but young and slim, with her two chairmen raising 'high tankards', punning she is "high glass", i.e. a "high class" whore. Capital punishment for "licentious humour" was recalled in 1748 in the Gentleman's Magazine: "this licentious humour was curbed by silencing the preachers and putting to death two or three tailors for some treasonal insolencies 
of which they had been guilty". ${ }^{65}$ Hogarth implies that fate via three tailors high up in a garret.

With Hogarth's Satire clear, the chronology of Beer Street can be contemplated. The central vignette varies between the preliminary drawing, the second engraved state, and the third engraved state. As with the woodcuts discussed previously, it is likely the earlier states reached public hands only after Hogarth's death. Absent from the preliminary drawing, Petit is added to the second state, but removed for the third. Why? Logic proposes Petit's experiments became known to Hogarth via attendance at Hunter's gravid uterus dissection. Hogarth determined to pressure Hunter by publicising Petit's words, and threatening Petit's portrait on Beer Street, as evidenced by his lone hand in dead centre of the preliminary drawing (Figure 40). In fright, Hunter undertook to halt his experiments, and Hogarth agreed to split the original set into pairs. He removed Petit to tone down Beer Street man-midwifery, but replaced Petit with new cryptic clues to Johnson, Irene, and Ann Gill; and introduced animal cruelty as a Sermon in the First Stage and the Second Stage.

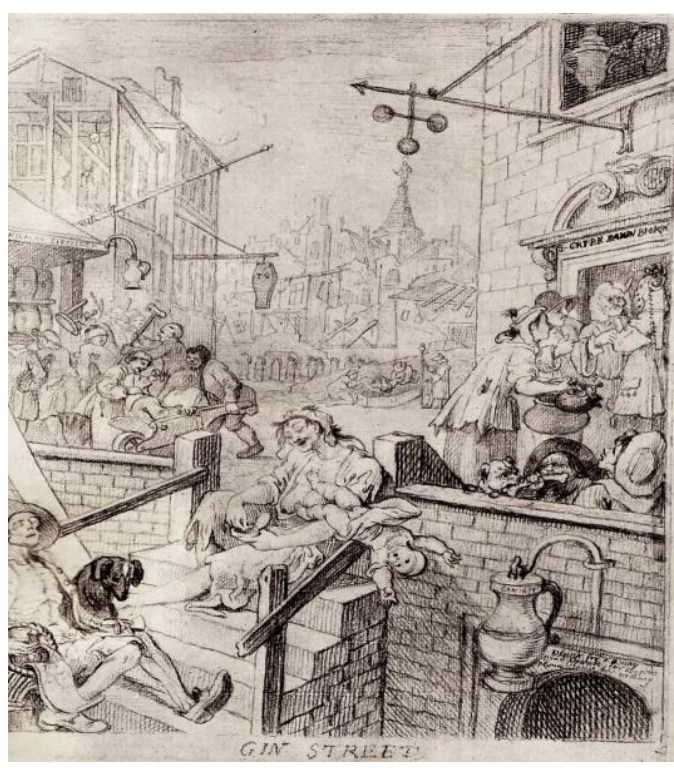

Figure 44. Gin Lane - Preliminary

drawing - Oppê: 74 (77)

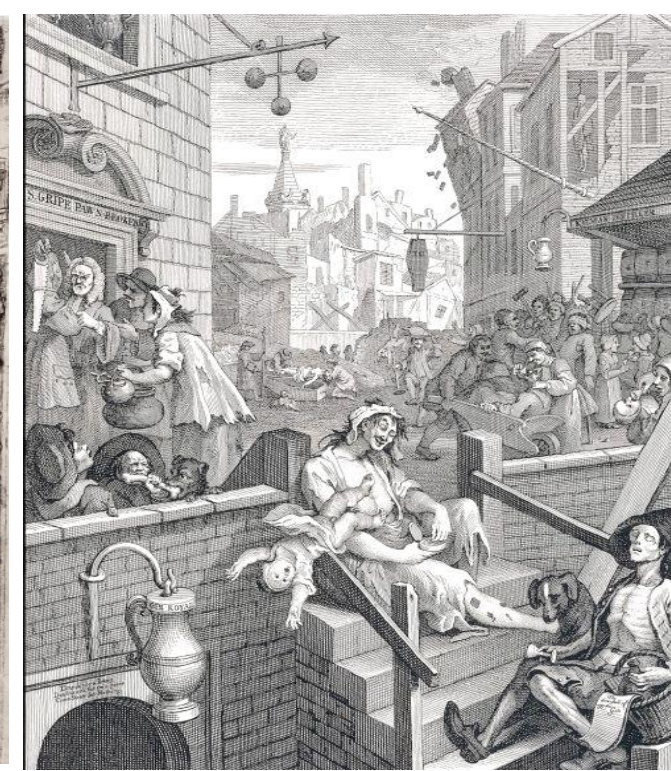

Figure 45. Gin Lane - Second State Paulson 199 (186)

Hogarth's ironic Satire continues in Gin Lane, as an attack focused more directly on anatomists; the clockwise vignettes itemising the varied sources of subjects-for-dissection (Figures 44-45). Be-spectacled Hunter, as a wealthy pawnbroker holds a coat and surgeon's saw, sign of a man murdered for dissection with his clothes pawned. Hunter is offered a pot for boiling bones, as in Reward. Two men are interring, or more likely snatching, a deceased body from a coffin under the conniving eye of a watchman, with a crying orphan as next target. A

65. Anon, The Gentleman's Magazine, vol. 18 (London: Cave, 1748), 444. 
funeral procession at the rear hints at the act of grave robbing. A man with a skewered baby ready for spit-roasting and bellows for the fire, is chased by the baby's mother, and recalls Swift's A Modest Proposal. People crushed, as in the falling building, were regular sources of subjects. The "hanging" coffin is marked "T G" for "Tyburn Gate", site of gallows for condemned felons. Hogarth saves the normal image for an executed felon of a hanged body, to show private suicides as sources, as inside the building. The helical tusk on the right alludes to the narwhal, its name derived from the Old Norse word nár for "corpse", a reference to the animal's greyish, mottled pigmentation, similar to that of drowned sailors, yet another source. The tusk puns a barber's pole, as prior to 1745 the Barbers' Company and the Surgeons' Company were a single company. Even the name of the distillery puns, "Kilman", for anatomists who "kill men". Two girls sipping gin risk a descent to prostitution and ruin, ending on an anatomist's dissection table. A child, and an adult in a barrow, are forcibly made drunk for easier sale to anatomists, with the blind and lame ready targets. As is a pauper dying in the foreground, and a woman in such a somnolent stupor, a snail is able to crawl onto her shoulder. That brings the scene full circle back to Hunter, and a man sharing a "smelly" bone with a "smelly" mastiff; he is "brute" Smellie; his covetous eyes target a bare breasted, destitute, mother abandoning her baby, and both at risk of being his subjects. In promoting the Foundling Hospital, and seeking to halt the widespread abandonment of infants by society, Hogarth's focal point is a pun on a woman abandoning her baby to take snuff, with an implied protest of, "it's enough!" ("it's snuff!").

The satiric bridge from Beer Street and Gin Lane to the satire within Perfection and Reward unites and, in continuing to Perfection, the fate of Ann Gill is clear. She did succumb to the dancing-bear owner, descended into prostitution, became pregnant and, destitute, sought charity and assistance for her imminent lying-in from Smellie. He murdered her during a Caesarean experiment; with his deserved fate reflected in Reward. The evidence endorses the view Hogarth split his original concept into two pairs, then added the First Stage and Second Stage. The original four prints, and issued set of six, all demonstrate simple Sermons, while retaining cryptic Satires.

\section{Stress Testing against the Preliminary Drawings}

A comparison of the satiric framework against Hogarth's preliminary drawings is valuable in stress-testing the conclusions. Study of the chronology indicates Hogarth commenced his concept with Perfection and Reward; then added the First Stage and Second Stage to give a veneer of animal cruelty. Paul Oppé made a valid observation, which now supports this interpretation, when he wrote in 1948; 
Strangely enough, one of the very best subjects in the Cruelty series for which forcible execution would be most suitable, presents one of the best examples of "fine drawing" in Hogarth's work. In the pencil drawing at Burghley for the First Stage (No. 70) everything, except the animals whose struggles have resulted in chaos, is set down gently, almost tenderly, and there is nothing either in the design or in the execution to suggest any emotion in the artist, or to communicate any feeling from him to the observer. In the elaborated version (No. 71) of this subject, ... everything tentative has been eliminated. ${ }^{66}$

Henry Reitlinger made a like comment in 1938, believing designs for the Idle and Industrious Apprentices must be regarded as a standard by which Hogarth's drawing style should be judged, as very free, nervous and impulsive. ${ }^{67} \mathrm{He}$ thought the highly finished Four Stages of Cruelty drawings stylistically had little in common with the sketches, with one free to surmise the presence of another hand in these. However, while Oppé and Reitlinger deserve respect as foremost scholars of their times, their views were expressed many years ago, in an academic environment which failed to read Hogarth's satire, chronology, and motivation. They made the assumption the design for Perfection and Reward followed the First Stage and Second Stage, rather than vice versa. Also presuming animal cruelty was his only intent.

Their views need revisiting, although their comments on Hogarth's artistry are not as inconsistent with the framework now advanced, as may have been expected. The structure is far more intricate, multi-levelled, and inter-related than most Hogarth's series, with a structure not conducive to a "very free, nervous and impulsive" style. Hogarth's anger and passion is evident in the composition of Perfection and Reward and by his singular action in preparing woodcuts. In the First Stage and Second Stage Hogarth was artistically constrained by a need to create images to precede, and provide a bridge to Perfection and Reward while including a dual message. On one hand a simple Sermon against animal cruelty, on the other, a cryptic Satire on human cruelty; where opportunity for artistic spontaneity was secondary to Hogarth's prime aim, Figures 46-49.

66. A. Oppé, The Drawings of William Hogarth (London: Phaidon, 1948), 15-16.

67. H. Reitlinger, From Hogarth to Keene (London: Methuen, 1938). 


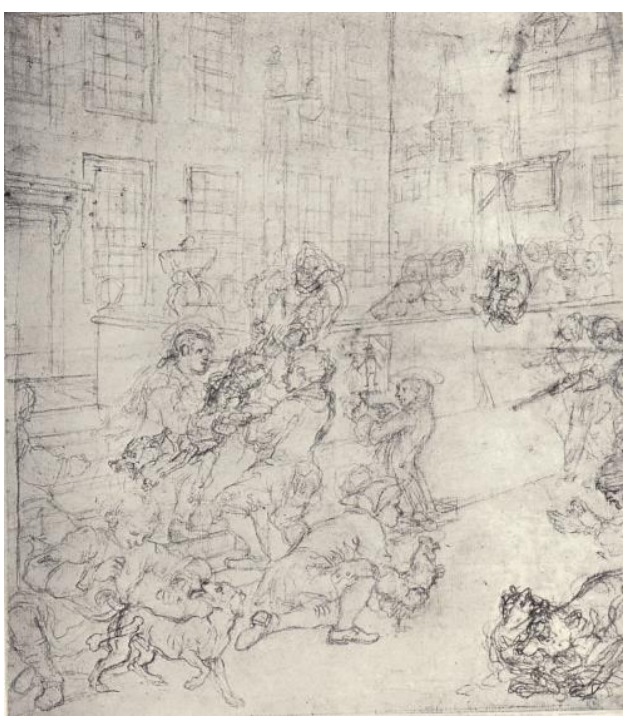

Figure 46. The First Stage of Cruelty preliminary drawing: Oppê: 67(70)

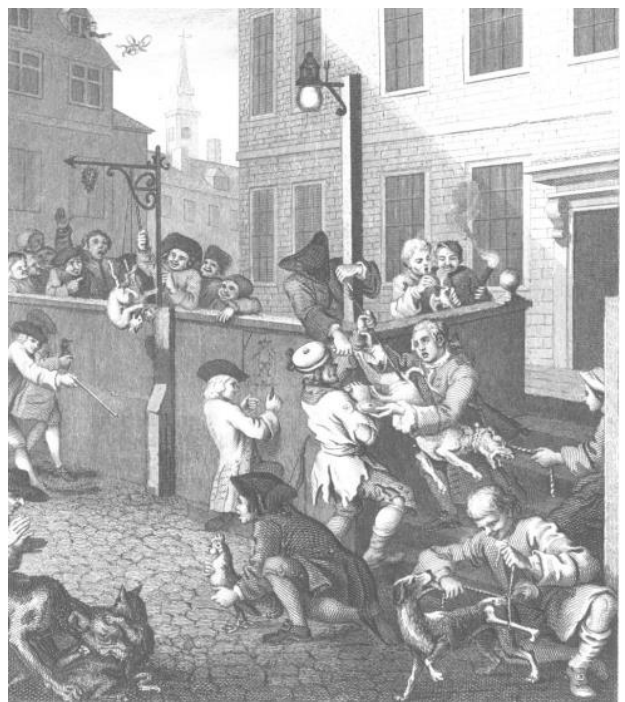

Figure 48. The First Stage of Cruelty

- engraving: Paulson: 187 (201)

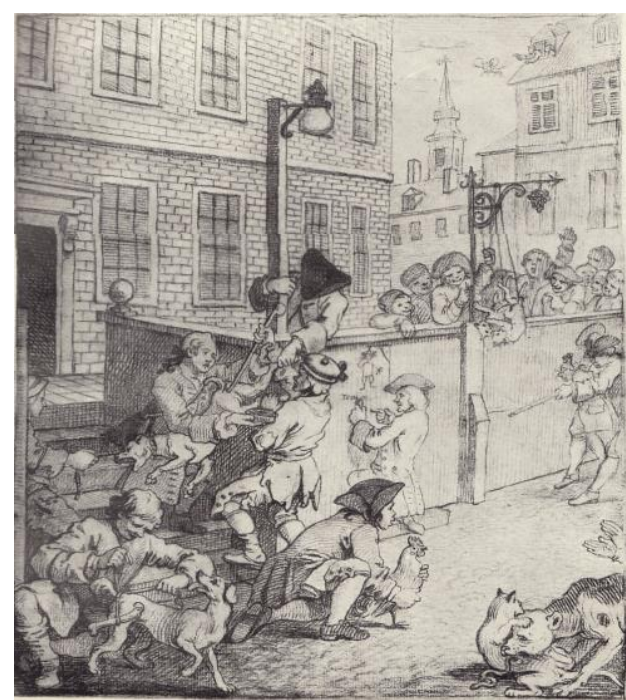

Figure 47. The First Stage of Cruelty secondary drawing:Oppê:68 (71)

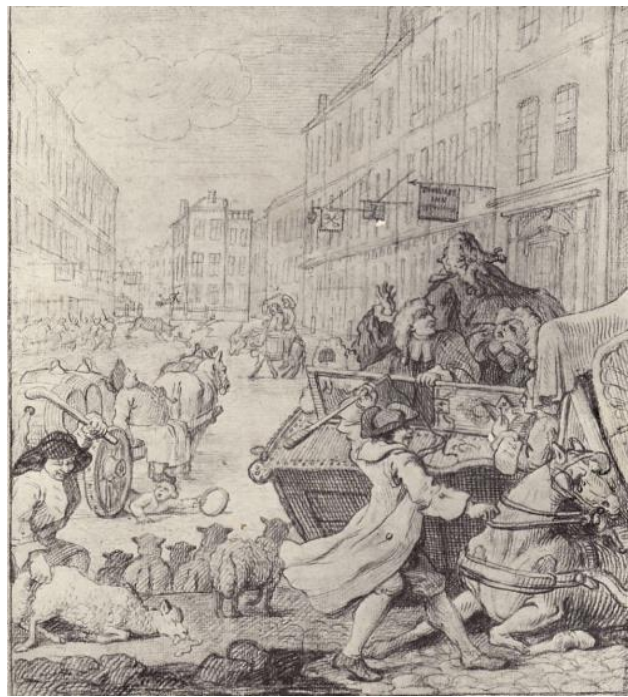

Figure 49. The Second Stage of Cruelty - secondary drawing: Oppê: 69 (72)

In the First Stage Hogarth began with a preliminary drawing depicting his main characters, surrounded by vignettes which grapple with the elements he needed to bring together; Smellie, the Hunters, van Rymsdyk, and his own selfportrait, together with puns on "tart", "fighting like cats", "cocking", and allusions to "hanging", "drawing" and "quartering"; all under a veneer of animal cruelty. His indecision in deciding how to depict puns involving moving animals, is evident in his repeated overdrawing of several animals. The preliminary and secondary drawings are similar, but with more characterisation and the bunch of grapes replacing a square inn sign. The name Nero is added to the wall to divert 
attention at animal cruelty, and away from those with recognisable features. A reference to "an eye for an eye" revenge is added by the boys blinding the eye of a bird, also adding initials SG/SC for Surgeons Company to the boy's shoulder. In the First Stage preliminary drawing, the nature of the item inserted into the dog is unclear, but in the second drawing is either a tube or a stick. In the engraving Hogarth reinforces his attack by changing the tube to an arrow, together with a bow, as symbols of Diana, Goddess of both Hunting and Childbirth.

In considering Hogarth's inspiration for the arrow, in 1785 John Nichols stated, "The thrusting an arrow up the fundament of a dog, is not an idea of English growth. No man ever beheld the same act of cruelty practised on any animal in London."68 But prior to an arrow Hogarth intended to show a tube; inspired by a letter published in London in 1747 by David Stephenson. Based at the Tower of London, he knew John Hunter, who obtained bodies of wild animals dying in the menagerie. Stephenson proposed many experiments with electricity, Experiment 18 proposing the use of electricity during Caesareans, if necessary for revival, and Experiment 11 mooted as:

Whether by putting a tube into the anus of any animal, the electric vapour may not be propagated through the whole compound intestinal canal to the mouth; and contrariwise from the mouth to the anus, and be transmitted also through the lacteal vessels to the blood, and so communicated to the whole animal system? ... And what effects will this æthereal vapour have, if communicated to the womb of animals either pregnant or not, and likewise to the urinary bladder. ${ }^{69}$

68. J. Nichols, Biographical Anecdotes of William Hogarth, 3rd ed. (London: Nichols, 1785), 317.

69. D. Stephenson, The Gentleman's Magazine, vol. 17 (London: Cave, 1747), 141. 


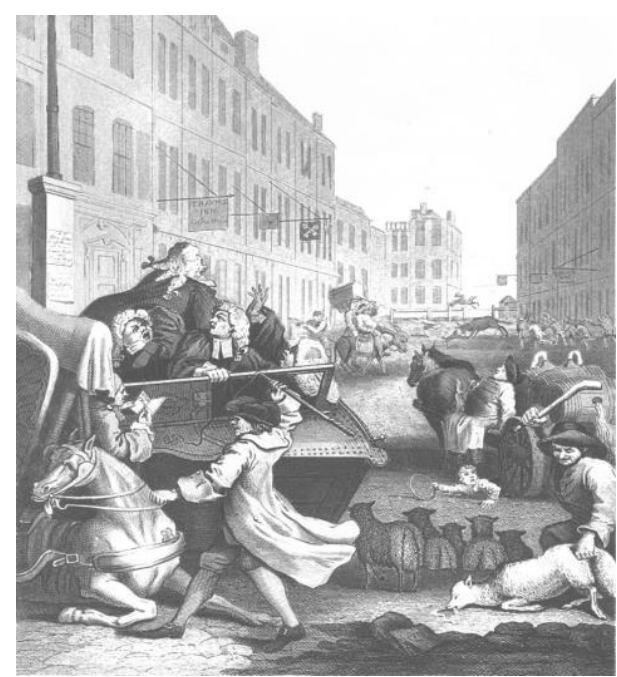

Figure 50. The Second Stage of Cruelty - engraving: Paulson: 188 (202)

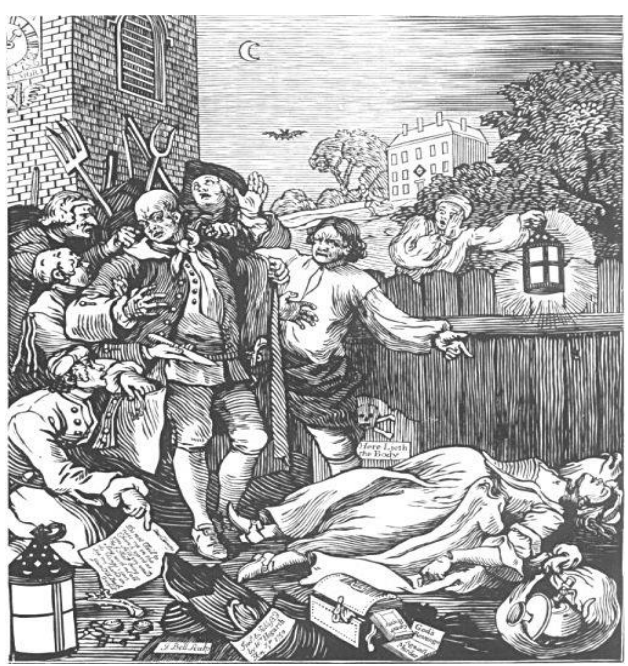

Figure 51. Cruelty in Perfection woodcut: Paulson: 189 (203)

No preliminary drawing for the Second Stage has been located, but a secondary drawing (Figures 49-50) focuses on Smellie and the Hunters, with a prostitution pun, "hoary" [whore]; in the verse, and vignettes alluding to "hanging", "drawing", and "quartering". The Fielding brothers are added and, in the secondary drawing, John has closed eyes to indicate his blindness. In the engraving Hogarth made changes to strengthen his attack, a pitchfork is applied to the overladen donkey representing man-midwifery impatience with parturient women in labour, and the number 24 replaces 4, to imply "two for" one, when murdering a pregnant woman and her baby. Added is a poster naming James Field, to strengthen a hint to Fielding.

There are three versions of Perfection, a woodcut with no preliminary drawing, a secondary drawing as model for the engraving, followed by the engraving (Figures 51-53). Changes between woodblock and engraving were discussed earlier. An intriguing difference between secondary drawing and engraving are initials on a casket in the foreground, the emptied casket representing an emptied womb. The change from " $\mathrm{E} G$ " to "A G" shows Hogarth developing the concept, originally E G for e.g., an example of a pregnant woman. Hogarth realised he could better make his "point" with a pun on "angle", in coining "Ann Gill". He added Ann Gill to the woodcut letter, even though the casket lacked initials. The initials aid with chronology; the letters on both woodcut and engraving are signed Ann Gill and the engraving has A G on the casket, whereas the secondary drawing shows E G on the casket. The name Ann Gill in woodcut and engraving implies the secondary drawing with " $E G^{\prime}$ " was drawn before Hogarth opted to use Ann Gill on the woodcut, adding credence to the view he prepared the design of the Perfection engraving before the 1 January 1750 date of the woodcut, and before the refocus on animal cruelty. If the 
secondary drawing had been made after the woodcut, Hogarth would have shown the casket initials as "A G".

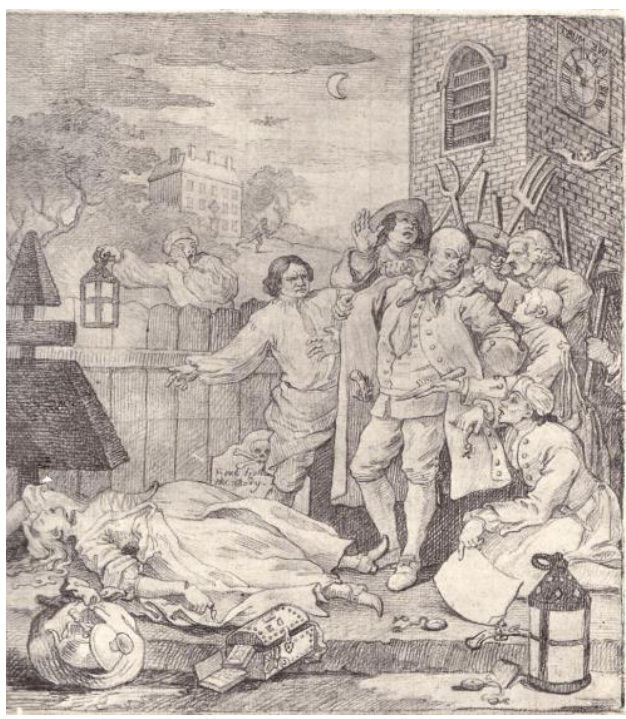

Figure 52. Cruelty in Perfection secondary: Oppê: 70 (73)

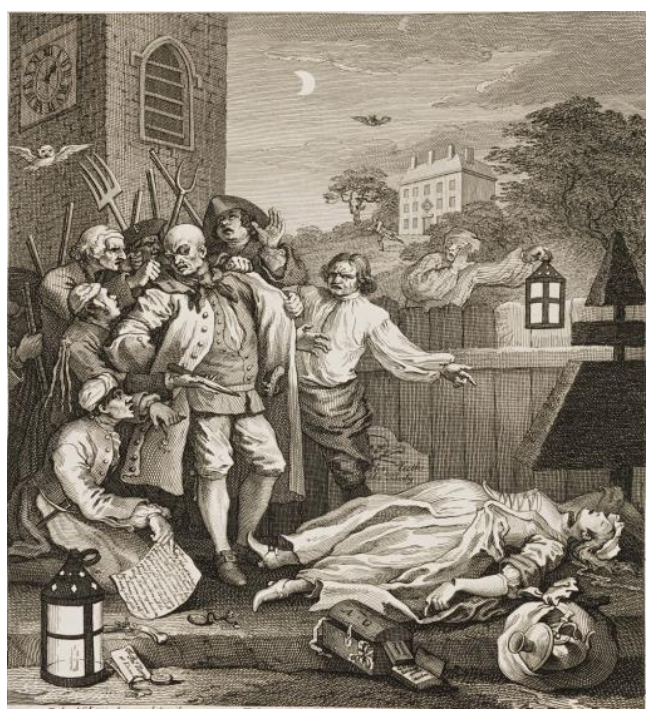

Figure 53. Cruelty in Perfectionengraving: Paulson: 279 (190)

A similar argument applies to an owl in the secondary drawing, but not in the woodcut. That reinforces Hogarth's need for woodcut proofs was urgent; he instructed Bell to cut them in parallel with cutting of copper plates for Perfection, Reward, Beer Street, and Gin Lane. Visages of William and John Hunter are the same in woodcut and secondary drawing, but altered in the engraving; a sign of parallel preparation of woodcut and engraving, and an undertaking to alter their visages for the engraving.

There are four versions of Reward (Figures 54-57). The woodcut incorporates changes from the preliminary drawing, where the visages are less characteristic, the bent nose of Frank Nicholls is not prominent, there is a third skeleton in a central niche instead of the presidential chair and coat of arms, and spectators lack academic head-wear. Hogarth adds spectacles to Hunter to stress his identity. Hogarth's line of thought is evident, as a left forefinger pointing at the "smelly" boiling pot is added to woodcut and engraving to reinforce Smellie's identity, whereas in the preliminary drawing his fist is merely clenched. In contrast with Perfection there is an indication the Reward woodcut was prepared before the secondary drawing. The rear figure of Hogarth has a snub nose in the secondary drawing, but not in the woodcut and his wig is different. He appears to be a late change for the engraving. If the secondary drawing was been made before 1 January, Hogarth would have shown himself in the woodcut with a snub nose. Other visages are similar as between the versions. 


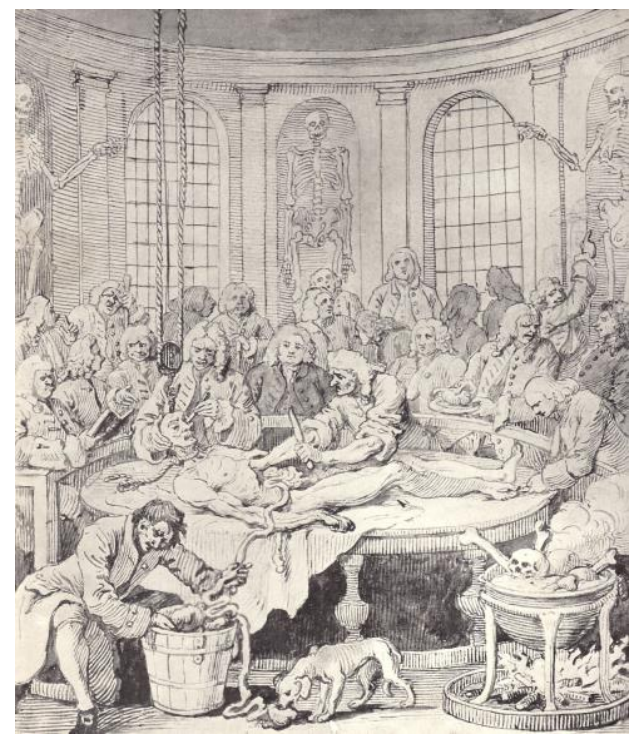

Figure 54. The Reward of Cruelty preliminary: Oppê: 71 (74)

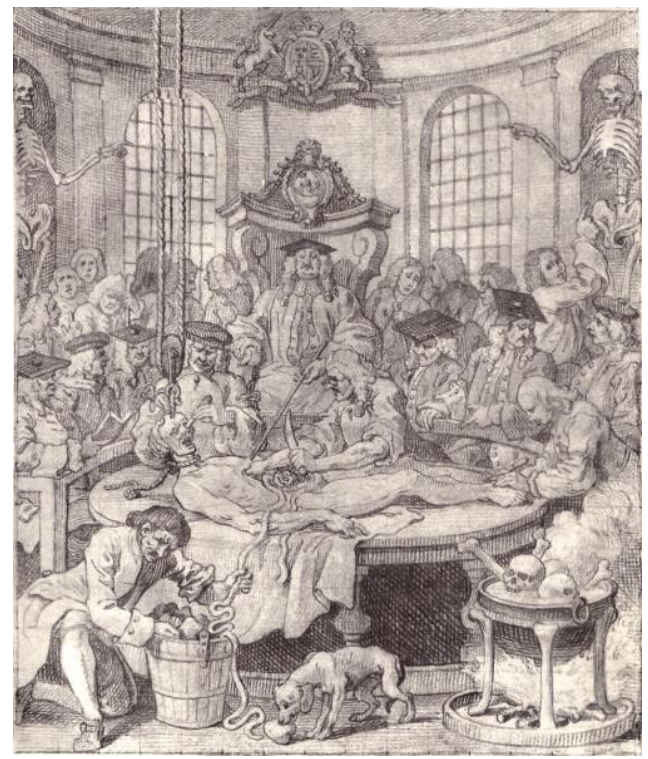

Figure 56. The Reward of Cruelty secondary: Oppê: 72 (75)

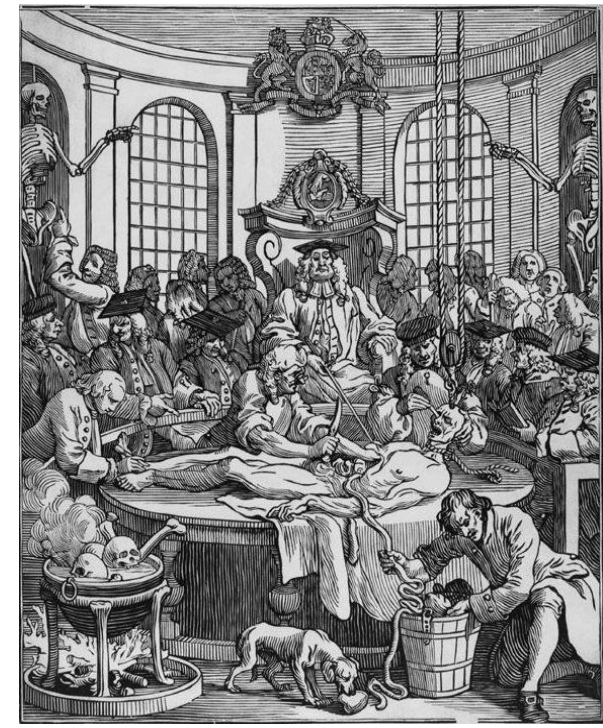

Figure 55. The Reward of Cruelty woodcut: Paulson: 203(189)

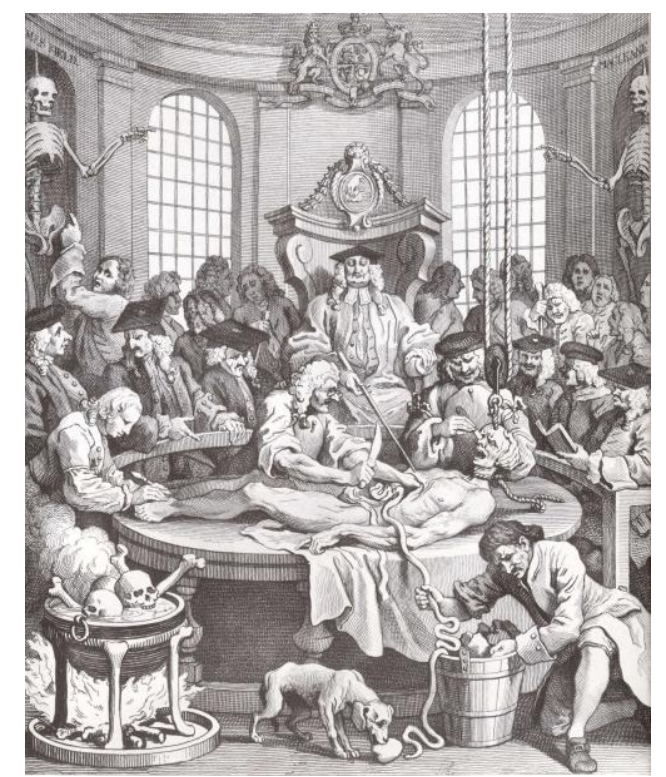

Figure 57. The Reward of Crueltyengraving: Paulson: 204(190)

\section{Tobias Smollett and A Dissertation on Mr. Hogarth's Six Prints}

On 28 February 1750 the General Advertiser announced; "This day is published ... Gil Blas ... A New translation by the author of Roderick Random." This was shortly after Four Stages of Cruelty was advertised on 13 February; a week 
later Smollett published his Peregrine Pickle, a novel mocking Hogarth as artist Pallet. Most of Smollett's works were published anonymously; with his authorship only known by those close to him. Key among his anonymous works is a 59-page pamphlet, A Dissertation on Mr Hogarth's Six Prints, published in April 1751, soon after Hogarth's prints. ${ }^{70}$ Largely overlooked by scholars, this pamphlet is believed to have inspired the 1751 observation: "One Man prints a Sermon, which may as well be called a Satire ... Our Poetry is all Prose, and our Prose is false English". ${ }^{11}$ In 1781 John Nichols published his Biographical Anecdotes of William Hogarth without mention of $A$ Dissertation, but in a second edition he refers to a "stupid pamphlet".

\section{For $F$ E B R U A R Y, 175r:}

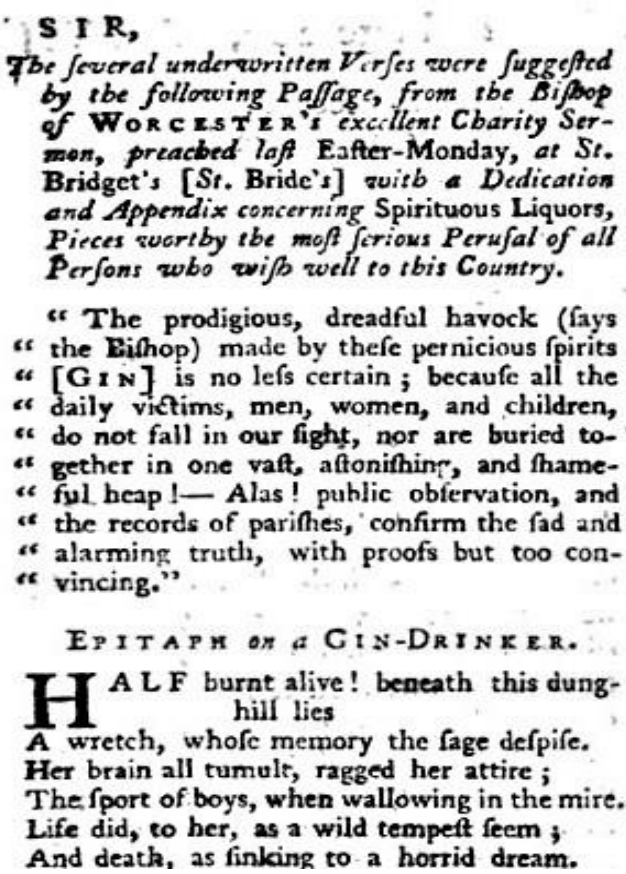
fruetion fhun,

Figure 58. Universal Magazine, 1751

A Dissertation quotes the Bishop of Worcester and, in implying a shared author, Universal Magazine, also quotes the Bishop; but accompanied by four satiric verses, (Figure 58). The fourth poem scorns a comedy version of Gil Blas by Edward Moore, and reinforces a Smollett attribution of $A$ Dissertation. Smollett had translated Gil Blas, and here contemptuously remarks: "I own, Gil Blas," and finds it "stranger still" the comedy version is "So full of Devil, and not damn'd". In the context, "Devil" is a pun on "Shit". Smollett wrote many poems, and multiple

70. T. Smollett, A Dissertation on Mr Hogarth's Six Prints ... (London: Dickinson, 1751).

71. C. Smart, The Midwife, or, The Old Woman's Magazine, vol. 2 (London: Carnan, 1751), 116. 
scatology allusions are often a clue to his pen; here the poem, Epitaph on a GinDrinker, also includes, "beneath this dung-hill lies" and "wallowing in the mire". To divert attention from Hogath's attacks on man-midwives Smellie and Hunter, Smollett's A Dissertation includes lengthy exaggeration of the evils of gin. It discusses Gin Lane and Beer Street in 32 pages; criticising Henry Fielding, as Chief Magistrate, for gluttony and lax enforcement of the law. Although purportedly a dissertation on Hogarth's series of six prints, Smollett makes only passing reference to the Stages of Cruelty: First Stage in three pages, Second Stage in two pages, Perfection in three pages, and Reward in three. Then, as a red-herring, sixteen pages discuss completely unrelated murders. The intent of $A$ Dissertation is clear, as a literary cacophony, sufficiently bold to divert scrutiny from Hogarth's challenge to Caesarean experiments by Smellie and Hunter. In this, Smollett was successful; with his misleading references to gin and animal cruelty, accepted, and then perpetuated by subsequent scholars.

\section{Paul Before Felix Burlesqued as a Stage of Cruelty}

A review of sources c.1749-52 reveals a range of concerned satire about the activities of anatomists and man-midwives, beyond those tabled here. A satiric thesis appeared in Newbery's The Student, likely written by Christopher Smart. The thesis purported to have been read before Haller, in October 1749, by F. G. Zinn (effigy [of] sin). It satirised dissections at Hunter's anatomy school in twelve gruesome examples, with explicit detail of the cruelty inflicted. Hunter inspired a Johnson satire in The Rambler on 29 December 1750, it was signed Quisquilius, Latin for rubbish, and directed at Hunter, a noted collector. In January 1751 The Rambler published a letter ruminating on mothers of Foundling Hospital children. 


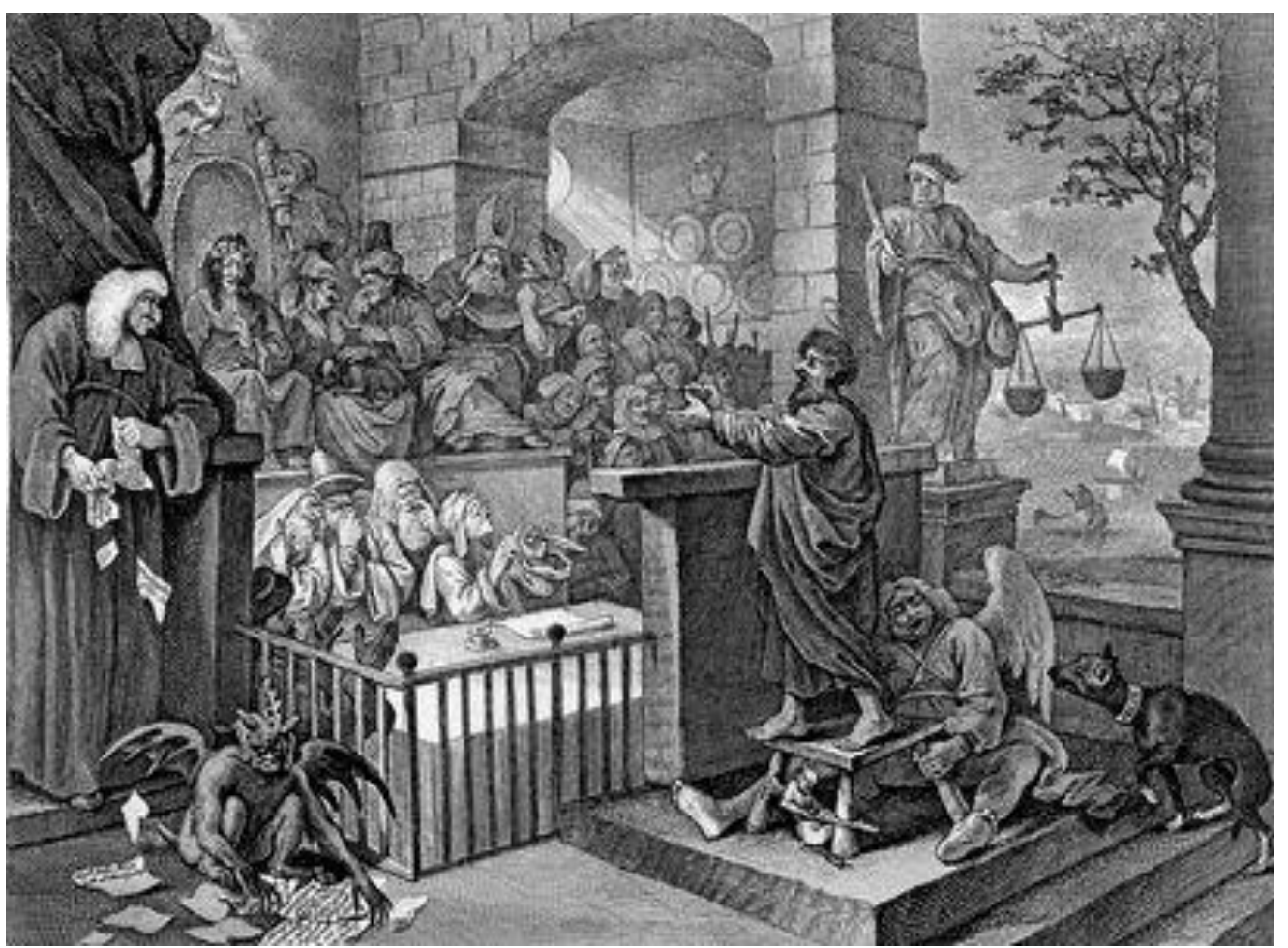

Figure 59. Paul Before Felix - Burlesqued - but implicitly The Trial of Smellie.

The ridicule of Hogarth in Peregrine Pickle, and Smollett's distortion of $A$ Dissertation so angered Hogarth, he opted to pillory Smollett in his May 1751, Paul before Felix Burlesqued, as a parody of a serious Hogarth print, Paul before Felix, at Caesarea (Figures 59-63). It could fairly be re-titled The Trial of Smellie, as its effective chronology nests between his crime, Perfection, and his punishment in Reward. A court of justice, and a location pun, Caesarea, confirm Smellie's Caesarean experiments; with a Dutch windmill across the water, proving the trial is in London. Clues that defendant Paul is Smellie, are spectators holding their noses against the "smell" or mouthing "smelly".

For his misleading defence in A Dissertation, Smollett, as Felix the judge, recoils at being required to judge his friend Smellie. Via a Tobias pun, Hogarth conveys the Bible message in the book of Tobias, is that God is both just and free, and in the long run rewards the just, and punishes the wicked. The scribe, sharpening a quill and blank pages, thereby puns Smollett has written nothing of value. Fielding is represented as Tertullus, the lawyer employed by the Jews to state their case against Paul, before Felix. Fielding tears up his prepared indictment on hearing Smellie confess, the discarded words reveal they are no longer irrelevant. 


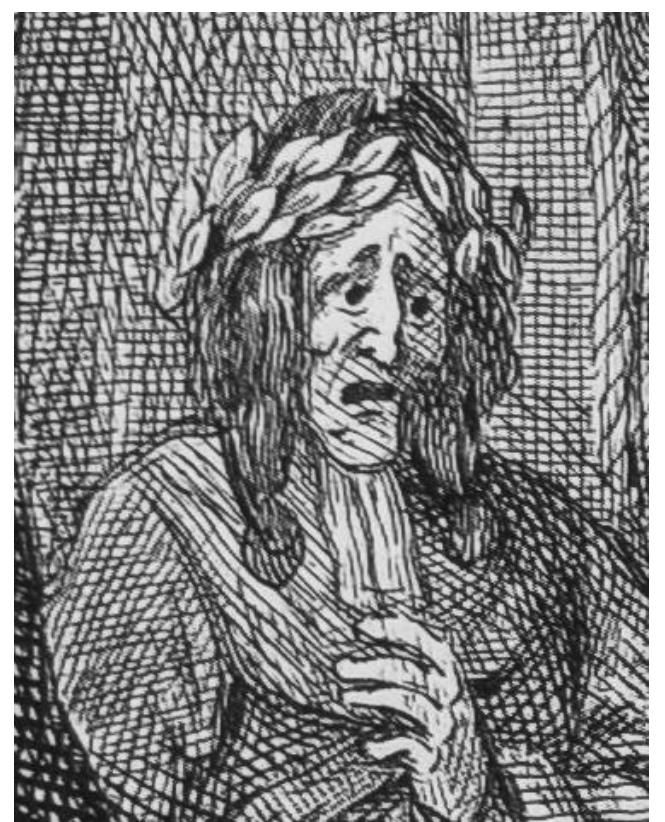

Figure 60. Smollett as Felix

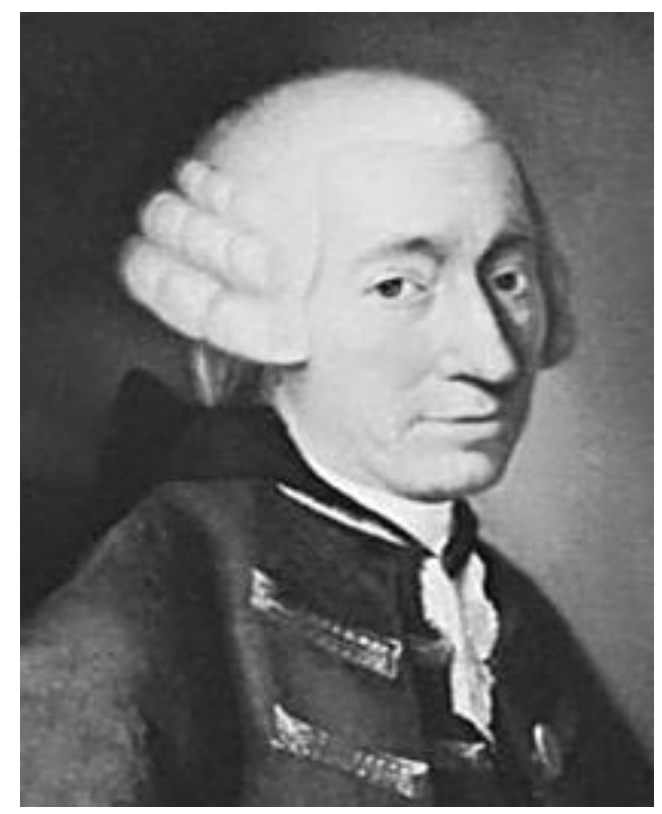

Figure 61. Tobias Smollett

The tree of knowledge leans towards Justice, portrayed as a midwife expert about medical facts around undelivered deaths. She wields as her licence, a knife bearing the arms of London, and as used for severing umbilical cords; one eye is uncovered as she judges the evidence, and scales await her verdict. Hunter is the biblical Ananias, of whom Peter stated, Ananias lied not to men, but to God, and died on the spot. He is restrained by a muscular man-midwife's arm, and is aghast at Smellie confessing; the halo and beam of light show Smellie is telling the truth. The dog from the First Stage waits to dine on Smellie's remains after he is dissected. The devils in the foreground satirise Smollett's claim to own Gil Blas, and pun on the reference to "Devil" in the Gil Blas verse, to show Smollett is also full of "Shit". The only support for Smellie is Lucifer, a fallen angel, representing Satan. A devil cuts the support from beneath Smellie; his crimes will result in his execution, and a fall into eternal damnation. 


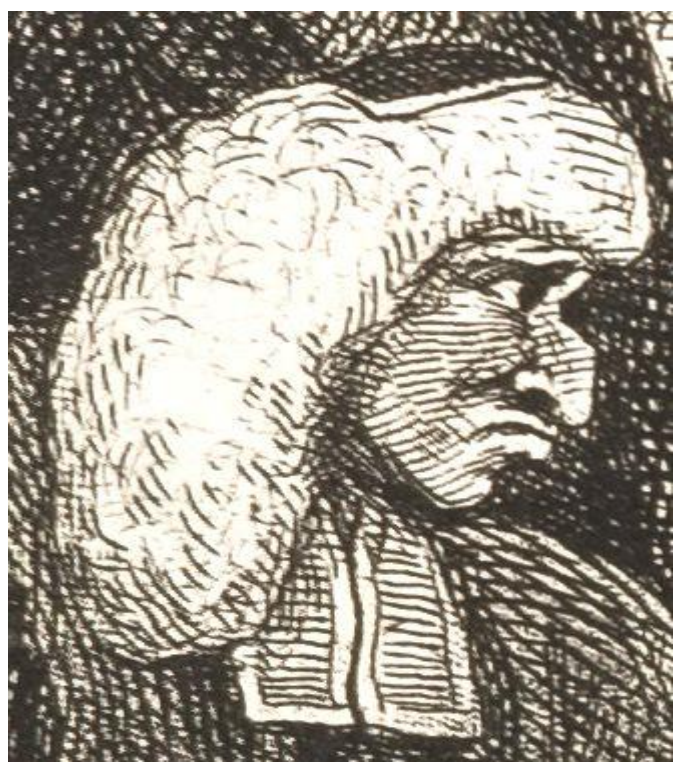

Figure 62. Fielding as Tertullus

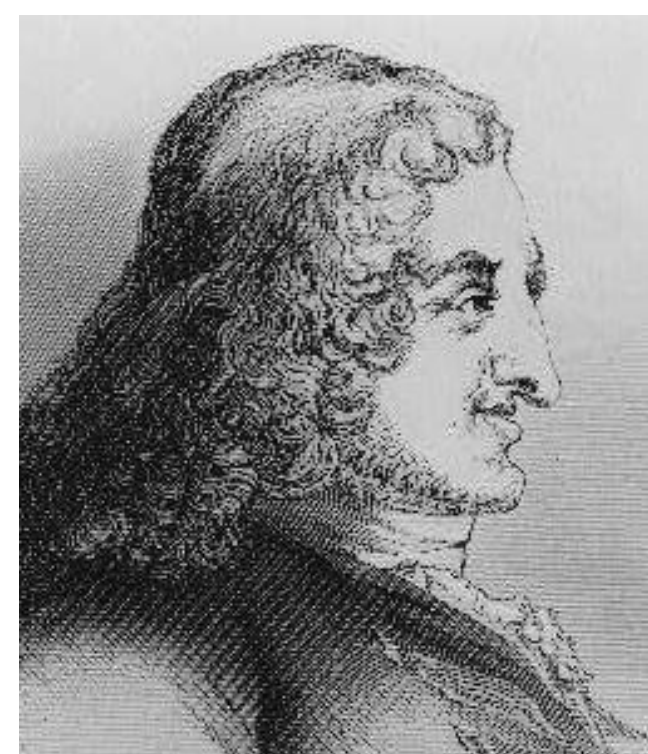

Figure 63. Henry Fielding

First issued only as a ticket receipt, Paul Before Felix Burlesqued was so popular, in December 1751 Hogarth had it re-engraved. Smollett was incandescent with shame as it circulated; shocked to see himself, but accepting Hogarth held the cards in any ongoing dispute. To admit defeat, in a 1758 edition of Peregrine Pickle, he revised his description of Pallet, to portray Hogarth more favourably.

In 1751 Smollett was editing Smellie's Treatise on Midwifery, whilst Fielding was writing and publishing Amelia. Smollett's "gluttony and gin" attacks prompted Fielding to pen Amelia as a side-swipe at Smollett's heroine, Emilia; with Booth as dextra to Pickle's sinistra. Added insult casts Smollett as the unnamed Author at Mr Bondum's sponging-house, an incident so removed from the plot it begs review.72 In Amelia Fielding has Booth meet the Author, clearly intended as Smollett, to probe the Author's knowledge; implying Author/ Smollett's pretence to a far greater knowledge of classics and literature than he possessed. Fielding has the Author observe "his Story of a Cock and a Bull is excellent", for Amelia readers to thereby interpret Peregrine Pickle as "a cock and bull story". Bondum comments of the Author: "He writes your History Books for your Numbers" and, of news "he makes it as he doth your parliament speeches for your Magazines". This supports a view Smollett as author of both the Lilliput Debates and Proceedings of the Political Club. As intimated by Smollett; Pickle "sent it to the author of a weekly paper, who had been long a professed reformer in politics; and it appeared in a very few days, with a note of the publisher, desiring the favour of a further correspondence with the author". ${ }^{73}$ In contrast, Fielding, as

72. H. Fielding, Amelia, ed. L. Bree (London: Broadview, 2010), 323-40.

73. T. Smollett, The Adventures of Peregrine Pickle, ed. J. Clifford (London: OUP, 1964), 
Booth, scathingly observes Author/Pickle/Smollett "was the most impudent and illiterate Fellow he had ever seen; and that, by his own account, he was the Author of most of the wonderful Productions of the Age".

Hogarth's print attacks on Smellie and Hunter remained behind this. Smollett had denigrated Fielding and Hogarth in seeking to defend Smellie and Hunter from risk of trial and execution. That stance was immoral in Fielding's eyes, with his opinion of Smollett conveyed to Hill on 9 January 1752: "The author of Amelia ... told me ... he held the present set of Writers in the utmost Contempt, and that in his Character of Drawcansir he should treat them in a most unmerciful Manner". ${ }^{74}$ Resentment over Smollett's "gluttony" attacks, was a factor in Fielding founding Covent-Garden Journal in December 1751. Selfpromoted as the "Journal of the present Paper War between the Forces under Sir Alexander Drawcansir and the Army of Grub-street", the 6 January 1752 issue contained a satire targeting Smollett:

The greater Part of these were garrisoned by Detachments from the Regiment of Grub-street, who all retired at the Approach of our Forces. A small Body, indeed, under the Command of one Peeragrin Puckle, made a slight Show of Resistance, but his Hopes were soon found to be in Vain; and, at the first Report of the Approach of a younger Brother of General Thomas Jones, his whole Body immediately disappeared, and totally overthrew some of their own Friends, who were marching to their Assistance, under the Command of one Roderick Random. This Roderick, in a former Skirmish with the People called Critics, had owed some slight Success more to the Weakness of the Critics, than to any Merit of his own. ${ }^{75}$

Smollett's embarrassment at Fielding's Amelia satire on him, as the Author, together with that on 6 January roused Smollett to respond on 15 January, in a venomous pamphlet, A Faithful Narrative of the Base and Inhuman Arts ... lately practised upon the Brain of Habbakkuk Hilding. ${ }^{76}$ Fielding reacted to Smollett's Hilding attack in 21 January 1752, with a satire on Trunk-makers and Pastry Cooks, ostensibly on the life and death of books, but thin cover for a charge of murder of pregnant women, "Many of them cut off in their very Prime; others in their early Youth; and others, again, at their very Birth; so that they can scarce be said ever to have been". Fielding puns include "Trunk-makers" as anatomists cutting off heads and limbs to convert dead bodies to trunks, and "Pastry Cooks"

$676-77$.

74. H. Fielding, The Covent-Garden Journal, vol. 1. ed. G. Jensen (New Haven: Yale, 1915), 42.

75. H. Fielding, The Covent-Garden Journal, vol. 1. ed. G. Jensen (New Haven: Yale, 1915), 145.

76. T. Smollett, A Faithful Narrative of the Base and Inhuman Arts .... (London: Sharp, 1752). 
as man-midwives who "take buns out of the oven", i.e. hunt fetuses. Fielding's message emerges: "The ingenious Hogarth hath very finely satyriz'd this, by representing several of the most valuable Productions of these Times on the Way to the Trunk-maker"; implying Smellie fated to become a "trunk" after the trial in Paul Before Felix Burlesqued.

Other puns include; "dismembering Authors" as dissecting bodies, "a Piece of Poetry" as a female sexual organ, "a Sheet of Romance" as a beautiful face, "mangled Libels" as mangled limbs, "Moderns" as the living, "best Performances" as dissections before invited audiences, cooked red "Juice of Gooseberries, Currants, and Damascenes" as blood and entrails, "wondrous Performances" preventing mother's milk as "Food for the Mouths of Babes and Sucklings", and "Tarts and Pies" as prostitutes at risk for "the Use and Inspection of the few", i.e. man-midwives. The phrases, "Arcana Naturæ" and "Denudations of Nature" refer to van Rymsdyk's anatomical drawings, and a fear they will be of prurient interest to the young:

Next to the Booksellers are the Trunk-makers, a Set of Men who have of late Years made the most deplorable Depredations on modern Learning. The ingenious Hogarth hath very finely satyriz'd this, by representing several of the most valuable Productions of these Times on the Way to the Trunkmaker. ... they seem to take a Delight in dismembering Authors; and in placing their several Limbs together in the most absurd Manner. Thus while the Bottom of a Trunk contains a Piece of Poetry, the Top presents us with a Sheet of Romance, and the Sides and Ends are adorned with mangled Libels of various Kinds. The third Species of these Depredators are the Pastry Cooks. What Indignation must it raise in a Lover of the Moderns, to see some of their best Performances stain'd with the Juice of Gooseberries, Currants, and Damascenes! But what Concern must the Author himself feel on such an Occasion; when he beholds those Writings, which were calculated to support the glorious Cause of Disaffection or Infidelity, humbled to the ignoble Purpose of supporting a Tart or a Custard! ... many of these wondrous Performances are calculated only for the Use and Inspection of the few, and are by no means proper Food for the Mouths of Bates and Sucklings. ... Lastly, there are certain Arcana Naturæ in disclosing which the Moderns have made great Progress, now whatever Merit there may be in such Denudations of Nature, if I may so express myself, and however exquisite a Relish they may afford to very adult Persons of both Sexes in their Closets, they are surely too speculative and mysterious for the Contemplation of the Young and Tender, into whose Hands Tarts and Pies are most likely to fall. ... I hope for the future, Pastry Cooks will be more 
cautious than they have lately been. In short if they have no Regard to Learning, they will have some, I hope, to Morality. ${ }^{77}$

In calling for morality by "Pastry Cooks", Fielding was warning Smollett of the risks from his attacks; as Hogarth had done with Paul Before Felix Burlesqued, to condemn Smollett's friends to trial and execution if Fielding wrote overtly, rather than covertly, on "Trunk-makers" and "Pastry Cooks". Fielding's 21 January satire reinforced Four Stages of Cruelty and Paul Before Felix Burlesqued, as well as the Petition of the Unborn Babes. The battle continued, with pamphlets and Fielding's satire on Pastry-Cooks prompting on 14 February 1752, A Vindication of Man-midwifery, a 20 page defence of Smellie and Hunter; and more Smollett polemics. It includes Biblical, medical, classical, and Latin references, even Swift's Tale of $a \mathrm{Tu} b$, and was satirically disparaging of women: "You will be pleased likewise to consider that Women are wholly illiterate, and never brought up to any Thing of Letters, beyond their Sample; Men on the contrary are always brought up to something or another." 78

On 10 March 1752 Fielding responded to Smollett's Vindication, using the case of Mary Blandy as a threat, in a long and caustic satire on man-midwifery describing Smellie as a "Wretch". Hidden inside a discussion of Blandy, but via a strong defence of women, "misled by Men" under the guise of man-midwifery. Fielding's reference to "Destruction, both of Body and Soul" is to obstetric murderfor-dissection; "an officer in the army" to Smellie's navy service; "eternal State of real Hostility with the female sex" to man-midwifery; and "to destroy our Wives and Daughters" to man-midwives' premature intervention in childbirth resulting in needless deaths:

Let us for a Moment only cast our Eyes on the Wretch, who hath caused all this, who hath hitherto escaped the Hands of Justice ... But I will leave this Wretch likewise to the Horrors of his own Conscience, to Wandering, to Beggary, to Shame, to Contempt. This Letter is designed for the Use of the loveliest, and I sincerely think, the best Part of the Creation, who seldom stray but when they are misled by Men; by whom they are deceived, corrupted, betrayed, and often brought to Destruction both of Body and Soul. In the Sequel therefore, I will treat in general of these Corrupters of the Innocence of Women, and of the extreme Baseness as well as Cruelty of this Practice, how favourably soever the World may please to receive it. This base and barbarous Man was, they say an Officer in the Army; a Sort of People who, I know not for what Reason, live in an eternal State of real Hostility with the female Sex; and seem to think that by destroying our

77. H. Fielding, The Covent-Garden Journal, vol. 1. ed. G. Jensen. (New Haven: Yale, 1915), 167-71.

78. Anon, A Vindication of Man-Midwifery ... (London: Carpenter, 1752), 6. 
Enemies in War, they contract a Right to destroy our Wives and Daughters in Time of Peace. ${ }^{79}$

In confirming the satire, Fielding alludes to "Ruin of a Woman," from obstetric experiments as, "the Subject of Mirth"; surgeons as "military Gentlemen" in an army of surgeons, and "new Laurels" as obstetric discoveries. "Levity" by "fashionable Authors" refers to Smollett's satires; Peregrine Pickle, A Dissertation, A Petiton, Habbakkuk Hilding and Vindication, and "this Practice" to murder-fordissection.

[T] he Ruin of a Woman is far from being regarded amongst our military Gentlemen, or indeed amongst others, with that Abhorrence and Detestation which it deserves. It is often made the Subject of Mirth: nay, I am deceived if, instead of being considered on the Man's Side as a Mark of Disgrace, it is not sometimes treated as a Point of Honour, viewed in the Light of a Victory, and thought to add new Laurels to those which have been acquired in the Field. The Reason of this, in a great Measure is the Levity with which this Matter hath been handled by some of our fashionable Authors; who instead of exposing so execrable a Vice in it's proper odious Colours, have given it the soft Term of Gallantry; have at most endeavoured to make it the Subject of Ridicule; I am afraid have even represented it in an amiable Light to their Readers. I will endeavour therefore to strip the Monster of all its borrowed Ornaments, and to display it in its native and true Deformity; such as I think cannot fail of attracting all that Abhorrence and Contempt which is its Due. I shall at present pass by all those dissuasive Arguments which Religion affords against this Practice. ${ }^{80}$

\section{Literary, Legal, Social, and Obstetric Legacies from Four Stages of Cruelty}

In representing Four Stages of Cruelty as a satire, this essay has noted clear likenesses compared to contemporary portraits. Implying those depicted were recognisable by their peers. In appearing soon after Four Stages of Cruelty, for Smollett to feign ignorance in A Dissertation, of those depicted, and of Hogarth's puns, strains credulity. For example page 35 of $A$ Dissertation praises the offer, in the First Stage verse, of a tart as food, which seeks to divert attention from "tart"

79. H. Fielding, The Covent-Garden Journal, vol. 1. ed. G. Jensen (New Haven: Yale, 1915), 255.

80. H. Fielding, The Covent-Garden Journal, vol. 1. ed. G. Jensen (New Haven: Yale, 1915), 255. 
as "prostitute": "How lovely is it to see him exerting his Benevolence, and striving with all his Might, and offering his sweet Morsel of a Tart, perhaps his whole Breakfast, to prevail on the cruel Tormentors to leave off their Barbarity". Smollett recognised red-herrings were vital in distracting viewers, as scrutiny would reveal Hogarth's intent. In misleading scholars, to imply Four Stages of Cruelty was a Sermon, rather than a Satire, Smollett succeeded, as his false trail led scholars astray for over 250 years.

Hogarth's message, whilst opaque for subsequent historians, was clear to Smellie and Hunter. Hogarth's concern about illegal procurement of subjects for dissection was not a new issue. The existing legislation provided an annual combined limit of only ten executed bodies for both Surgeons' Company and Physicians' Company. The objectives of Hunter and Hogarth merged in 1751. Hunter to reduce his risk of arrest, and seek legal access to more corpses for teaching and research, whereas Hogarth had concern about murder-fordissection.

Publishing of Four Stages of Cruelty was a tipping point in a behind-thescenes debate and, given subsequent events, reached Prime Minister Pelham. Fielding's portrait in the Second Stage stirred him to action: the theme was clear, Hogarth's concern at murder of subjects by Smellie, Hunter, and other anatomists, together with the law's inaction in punishing the murderers. Lobbying by the unlikely alliance of Fielding, Hunter, and Hogarth resulted in the 1752 Murder Act, removing the legal limitation on dissection of executed felons, in words close to the 1746 letter: "after such execution, the body shall be delivered by the sheriff to the surgeons company, who shall give a receipt for it, and cause it to be dissected and and anatomized ... in no case shall the body of any murderer be suffered to be buried unless it shall have been so dissected and anatomized". ${ }^{81}$ The Act thus enshrined The Reward of Cruelty, in making surgeons executors of the sentence and linking dissection to criminal justice.

Ripples from Four Stages of Cruelty continued, although reducing in intensity after Fielding's 1754 death. Although Hogarth was proud in a belief he had halted obstetric experiments, neither he nor Fielding could make a public claim or discuss their efforts, being at physical risk at public wrath from any wider knowledge. On 15 November 1753 King George II opened Parliament, saying, "It is with the utmost regret I observe, that the horrid crimes of robbery and murder, are, of late, rather increased than diminished. I am sensible that works of reformation are not to be effected at once; but everybody should contribute their best endeavours; and let me earnestly recommend it to you, to continue your serious attention to this important object" ${ }^{82}$ Given the timing, amid a decline in Old Bailey murder convictions, the King's words were for public consumption; really referring to robbery of graves and murder-for-dissection. As availability of

81. Anon, The Scots Magazine (Edinburgh: Sands, 1752), 242-43.

82. Anon, London Magazine, and Monthly Chronologer (Dublin: Exshaw, 1753), 579. 
executed bodies remained insufficient, murder and grave-robbing continued, rising over the next eighty years as public opinion turned against executions, and resulting in the 1832 Anatomy Act.

Smellie continued with secret obstetric experiments, even after Four Stages of Cruelty. In July 1752, Peter Camper, a Dutch man-midwife and anatomist travelled to London to undertake forceps experiments with Smellie, and draw images of their use on freshly murdered pregnant cadavers. As evidence of muderous intent, Camper needed to be certain, before leaving Holland, that Smellie would have pregnant subjects available to dissect. ${ }^{83}$ Progressive images demonstrating the use of forceps on a murdered woman, as drawn by Camper, appear as Smellie's Tables XII and XVI-XIX. The drawings include minor rearrangement of cadavers and fetuses of victims, to better demonstrate abnormal fetal presentations: then included Smellie's atlas as published in $1754 .{ }^{84}$ Most other plates were drawn by van Rymsdyk in 1750. Twelve of Smellie's fifteen undelivered victims are at or near full term, with Tables X-XV revealing mothers killed during progressive stages of labour to study the turning of the head during descent. The evidence of murder in Smellie's atlas was obvious to midwives; as noted by Elizabeth Nihell, "you will find the merit of [Smellie's] whole works shrink to little or nothing, under the appraisement of common sense" ${ }^{\prime 85}$

Henry Fielding died in 1754 and was succeeded by brother John, but the latter's blindness prevented him from seeing the evidence of murder in the atlas. Publishing of Smellie's atlas and its evidence, raised concern among manmidwives. Mackenzie was dismissed by Smellie in 1755, supposedly for dissecting without consent, but in reality to provide Smellie with a scapegoat if one became necessary. In 1756 George Macaulay convened London manmidwives, under guise of a discussion over the contracted pelvis. As a result, Smellie, Hunter, John Hunter, Jenty, Burton, Harvie, and Mackenzie all ceased gravid uterus research. John Hunter and Jenty joined the army and van Rymsdyk left for Holland; re-emerging in Bristol as an impecunious artist, then returning to London when research resumed after Hogarth's 1764 death.

Hunter continued secret Caesarean experiments with five undelivered subjects dissected in 1750-54 and twelve more in 1764-74. In the interim, 1754-64, Hunter's peers criticised his "holier than thou" adoption of an excessively rigid stance against Caesareans, a sign of his fear of exposure. Hunter's atlas was eventually published in 1774, focussing on changes from embryo to birth, and his preface discussing the final stages of pregnancy; "The pregnant uterus undergoes such gradual changes from the time of conception to the hour of delivery, that in giving the anatomy of this part it will be necessary to fix upon some one time in

83. P. Camper, "Itinera in Angliam", Opuscula Selecta Neerlandicorum, vol 15. (Amsterdam, Sum. Soc., 1939), 121-165.

84. W. Smellie, A Sett of Anatomical Tables with Explanations ... (London: Freeman, 1754).

85. E. Nihell, A Treatise on the Art of Midwifery (London: Morley, 1760), 147. 
the wide period of nine months". 86 To have studied "such gradual changes" in the uterus to "the hour of delivery", not "the day of delivery", confirms Hunter had conducted multiple Caesarean dissections of full term murdered subjects.

Despite the evidence of murder in his atlas, Hunter prevaricated about Caesareans: "In London, Dr. Hunter, in thirty-nine years extensive practice never met but one instance, where it was necessary to have recourse to the Caesarian operation, and that case proved fatal" ${ }^{87}$ As Hogarth's engravings containing Hunter's image continued to circulate when Hunter published his atlas in 1774, his concern about a potential charge of murder caused him to defer publishing any descriptions of the plates. They remained unpublished at William's 1783 death, also at John's 1793 death, only being revised, sanitised, and published by Baillie in 1794, more than 40 years after van Rymsdyk made his initial drawings. ${ }^{88}$

As close friend of Smellie and Hunter, Smollett was aware of their murder of prostitutes, the nature of Caesarean research, and of Hogarth's concern. Smollett made a practice of defending doctors, especially Scots. In 1750/51 Smollett was sanitising, to remove any murder inferences in Volume I of Smellie's A Treatise on the Theory and Practice of Midwifery, later also editing Volumes II and III. ${ }^{89}$ Evidence of Smollett's sanitising, given the obstetric need to understand reasons for undelivered deaths, is that not a single undelivered example, as depicted in Smellie's atlas, is included among 531 midwifery cases discussed in Smellie's Treatise; nor is there any reference to undelivered deaths in the 1370 pages of the Treatise.

The two atlases contain seventy forensic quality plates of dissected pregnant women, as eighteenth century equivalents of modern autopsy photographs. They depict 32 murdered women and fetuses, one with twins, thereby 65 victims; a total in conflict with Hunter's claim in his preface, "the opportunities for dissecting the human pregnant uterus at leisure, very rarely occur. Indeed, to most anatomists, if they happen at all, it has been but once or twice in their whole lives". The depictions in the two atlases are representative examples of total victims, more must be among the 400 obstetric preparations still housed at the Hunter Collection in Glasgow, with even greater numbers murdered for teaching purposes now lost to history. The evidence of murder in the atlases of Smellie and Hunter has lain unremarked for over 250 years.

86. W. Hunter, The Anatomy of the Human Gravid Uterus (Birmingham: Baskerville, 1774).

87. W. Dease, Observations in Midwifery (Dublin: Williams, 1793), 71.

88. W. Hunter, An Anatomical Description of the Human Gravid Uterus (London: Johnson, 1794).

89. W. Smellie, A Treatise on the Theory and Practice of Midwifery (London: Wilson, 1752), 64. 


\section{Concluding Remarks}

Hogarth believed he had halted obstetric cruelty, and saved many innocent lives via the 1752 Murder Act. He assumed his threat was so powerful neither Smellie nor Hunter would dare resume Caesarean experiments, but Smellie continued secret experiments with Camper in 1752, before limiting himself to routine man-midwifery after 1755 , and retiring to Scotland in 1759 . Hunter continued secret experiments until Smellie's atlas was published in 1754; then paused, before resuming obstetric research with his brother John and van Rymsdyk in 1764, as they believed the risk of exposure had receded on Hogarth's 1764 death.

A logical question is why Hogarth's satire in Four Stages of Cruelty has remained unnoticed? The short answer was secrecy in a male-dominated medical world, but Smollett's anonymous and misleading defence in A Dissertation was also a factor in diverting attention. Secret anatomical research based upon murder of men, women, and children continued as a closed shop.

Historical truths revealed by study of the two anatomical atlases, and of Hogarth's prints, suggest medical historians need to go beyond limits of the written word, and bring art into the research orbit. Modern histories of British anatomy such as Cunningham (2010), lack scrutiny of the 72 plates of undelivered subjects depicted in the anatomical atlases of Smellie and Hunter. The omission means undelivered deaths and murder are unmentioned in texts on maternal mortality, infant mortality, and man-midwifery ${ }^{90}$. Unaccountably, that disconnect, and the clear evidence of murder for dissection, are unaddressed by modern biographers of Smellie ${ }^{91}$ and John Hunter ${ }^{92}$. Instead, Smellie, Hunter, and the experiments, are portrayed with admiration.

It may be asked whether the atlases of Smellie and Hunter should be withdrawn to respect the innocent victims depicted, with wet and dry preparations of victims still housed in the Glasgow Hunterian Museum and London Hunterian Collection being respectfully buried. That is seen as impractical, instead it is proposed medical collections display a prominent "Unknown Patient" memorial, acknowledging their preparations include subjects murdered by anatomists. Where the atlases and preparations are used for teaching purposes, it should be stressed they are memorials to unknown victims, and not trophies.

90. J. Donnison, Midwives and Medical Men (London: Heinemann, 1988); I. Loudon, Death in Childbirth (Oxford: OUP, 1992); A. Wilson, The Making of Man-midwifery (London: UCL, 1995); R. Woods, Death before Birth (Oxford: OUP, 2009).

91. H. King, Midwifery, Obstetrics, and the Rise of Gynaecology (Farnham: Ashgate, 2007).

92. W. Moore, The Knife Man (London, Bantam, 2005). 


\section{Acknowledgement}

While solely responsible for any residual errors, the author is grateful to medical professionals and academics who kindly answered questions and made helpful suggestions over a lengthy period, including; Irvine Loudon, Jean Donnison, Ludmilla Jordanova, Malcolm Parsons, Ronald Paulson, Bernd Krysmanski, Lynda Williams, Ronald Jones, and George Rousseau. This paper confirms a remark, "there is compelling evidence the artist William Hogarth in his 1751 series of prints, The Four Stages of Cruelty ... challenged Smellie and Hunter over the murder of pregnant women," in "Man-midwifery History 17301930": Journal of Obstetrics and Gynaecology (Shelton 2012). Many illustrations are reduced, with thanks, from those in (Oppé 1948) and (Paulson 1971), which should be referred to, for larger images. The essay is dedicated to the unknown victims of Smellie and Hunter, especially those so cruelly dissected, and depicted in their atlases.

\section{Bibliography}

Anon. The Petition of the Unborn Babes... London: Cooper, 1751.

Anon. The London Chronicle, vol. 12. London: J. Wilkie, 1762.

Anon. The Scots Magazine. Edinburgh: Sands, 1752.

Anon. The Gentleman's Magazine, vol. 18. London: Cave, 1748.

Aronson, J. "When I use a Word." BMJ (2000): 321.

Bernard, J. A General Dictionary, Historical and Critical, vol. III. London: Strahan, 1735.

Burton, J. An Essay Towards a Complete New System of Midwifery. Hodges, 1751.

Burton, J. A Letter to William Smellie MD, Containing critical and practical remarks upon his Treatise on the theory and practice of midwifery. London: Owen, 1753.

Camper, P. "Itinera in Angliam", Opuscula Selecta Neerlandicorum, vol 15. Amsterdam: Sum. Soc., 1939.

Clerk, T. The Works of William Hogarth. Edinburgh: Scholey, 1812.

Cook, J. The London Magazine, vol. 37. London: Baldwin, 1768.

Cook J and Cook B. Man-midwife, Male Feminist the Life and Times of George Macaulay, M.D., Ph.D. Ann Arbor: University of Michigan, 2004.

Cunningham, A. "William Hogarth": The Lives of the Most Eminent British Painters and Sculptors, London: Murray, 1830.

Cunningham A. The Anatomist Anatomis'd. Farnham: Ashgate, 2010.

Dease, W. Observations in Midwifery. Dublin: Williams. 1793.

Donnison, J. Midwives and Medical Men. London: Heinemann, 1988.

Douglas, W. A Letter to Dr Smelle, .... London: Roberts, 1748.

Exton, B. A New and General System of Midwifery. London: Owen, 1751.

Fielding, H. The History of the Adventures of Joseph Andrews. London: Millar, 1742.

Fielding, H. An Enquiry Into the Causes of the Late Increase of Robbers, $\&$ c. London: A. Millar, 1751.

Fielding, H. The Covent-Garden Journal, vol. 1. ed. G. Jensen. New Haven: Yale, 1915. 
Fielding, H. Amelia, ed. L. Bree. London: Broadview, 2010.

Gay, J. Poems on Several Occasions, vol. 1. London: H. Lintot, 1745.

Haslam, F. From Hogarth to Rowlandson. Liverpool: Liverpool University, 1996.

Heber, R. An Historical List of Horse-Matches Run and of Plates and Prizes. London: Heber, 1752.

Hunter, W. The Anatomy of the Human Gravid Uterus. Birmingham: Baskerville, 1774.

Hunter, W. Two Introductory Lectures, Delivered by Dr. William Hunter. London: Johnson, 1784 .

Hunter, W. An Anatomical Description of the Human Gravid Uterus. London: Johnson, 1794.

Johnson, S. "The Idler." In The Gentleman's Magazine, vol. 28. London: Cave, 1758.

King, H. Midwifery, Obstetrics, and the Rise of Gynaecology. Farnham, Ashgate, 2007.

Lamb, C. "On the Genius and Character of Hogarth ...". The Reflector, vol. 2. London: Hunt, 1811.

Loudon, I. Death in Childbirth. Oxford: OUP, 1992.

Mines, J. A Tour around New York. New York: Harpers, 1892.

Monro, A. Medical Essays, vol. 1. Edinburgh: Monro, 1737.

Monro, D. "The Dissection of a Woman with Child", Essays and Observations, vol. 1, Edinburgh, Hamilton, 1754.

Moore, W. The Knife Man. London, Bantam, 2005.

Nichols, J. Biographical Anecdotes of William Hogarth, 1st ed. London: Nichols, 1781.

Nichols, J. Biographical Anecdotes of William Hogarth, 2nd ed. London: Nichols, 1782.

Nichols, J. Biographical Anecdotes of William Hogarth, 3rd ed. London: Nichols, 1785.

Nichols, J B. Anecdotes of William Hogarth. London: Nichols, 1833.

Nihell, E. A Treatise on the Art of Midwifery. London: Morley, 1760.

Nokes, D. Samuel Johnson - A Life. New York: Henry Holt, 2010.

Oppé, A. The Drawings of William Hogarth. London: Phaidon, 1948.

Paulson, R. Hogarth, His Life, Art, and Times, vol. 2. New Haven: Yale, 1971.

Paulson, R. Hogarth Art and Politics, 1750-1764, New Bruswick, Rutgers, 1993.

Peachey, G. A Memoir of William \& John Hunter. Plymouth: Peachey, 1924.

Petit, J. "Remarks on various faulty conformations of the Anus in new born Children", ed. M de la Peyronie, Memoires of the Royal Academy of Surgery, vol. 1. London: Cave, 1750.

Poquelin, J-B. The Works of Moliere, French and English, vol. 3. London: Watts, 1739.

Porter, R. Bodies Politic: Disease, Death, and Doctors in Britain, 1650-1900. London: Reaktion, 2001.

Reitlinger, H. From Hogarth to Keene. London: Methuen, 1938.

Van Rymsdyk, J. Museum Britannicum ... London: Moore, 1778.

Seligman, S. "The Royal Maternity Charity: The First Hundred Years." Med Hist, 24, no $4(1980)$.

Shelton, D. “Man-midwifery history: 1730-1930." J Obstet Gynaecol., 32, no. 8(2012).

Smart, C. The Midwife, or, the Old Woman's Magazine, vol. 2. London: Carnan, 1751.

Smellie, W. A Treatise on the Theory and Practice of Midwifery. London: Wilson, $1752 .$.

Smellie, W. A Sett of Anatomical Tables with Explanations ... London: Freeman, 1754.

Smollett, T. A Dissertation on Mr Hogarth's Six Prints ... London: Dickinson, 1751.

Smollett, T. A Faithful Narrative of the Base and Inhuman Arts .... London: Sharp, 1752.

Smollett, T. The Adventures of Peregrine Pickle, ed. James Clifford. London: OUP, 1964.

Steintrager, J A. Cruel Delight: Enlightenment Culture and the Inhuman. Bloomington: Indiana, 2004. 
Stephenson, D. The Gentleman's Magazine, vol. 17. London: Cave, 1747.

Swift, J. A Modest Proposal .... Dublin: Bickerton, 1729.

Swift, J. “Polite Conversation." Miscellanies, 4th ed., vol. 9. London: Davis, 1748.

Thornton, J. Jan van Rymsdyk Medical Artist of the Eighteenth Century Cambridge: Oleander, 1982.

Trusler, J. Hogarth Moralized: Being A Complete Edition of Hogarth's Works. London: Hooper, 1768.

Vartan, C. “The Lying-in Hospital 1747.” Proc R Soc Med. 65, no 5(1972).

Walpole, H. Anecdotes of Painting in England, vol. 4. London: Dodsley, 1782.

Wilson, A. The Making of Man-midwifery. London, UCL, 1995.

Woods R. Death Before Birth, Oxford.OUP, 2009. 
